San Jose State University

SJSU ScholarWorks

Master's Theses

Master's Theses and Graduate Research

1994

\title{
Characterization of rare plant habitat for restoration in the San Bernardino National Forest
}

Michael P. Gonella

San Jose State University

Follow this and additional works at: https://scholarworks.sjsu.edu/etd_theses

\section{Recommended Citation}

Gonella, Michael P., "Characterization of rare plant habitat for restoration in the San Bernardino National Forest" (1994). Master's Theses. 756.

DOI: https://doi.org/10.31979/etd.ehb8-frgq

https://scholarworks.sjsu.edu/etd_theses/756

This Thesis is brought to you for free and open access by the Master's Theses and Graduate Research at SJSU ScholarWorks. It has been accepted for inclusion in Master's Theses by an authorized administrator of SJSU ScholarWorks. For more information, please contact scholarworks@sjsu.edu. 


\section{INFORMATION TO USERS}

This manuscript has been reproduced from the microfilm master. UMI films the text directly from the original or copy submitted. Thus, some thesis and dissertation copies are in typewriter face, while others may be from any type of computer printer.

The quality of this reproduction is dependent upon the quality of the copy submitted. Broken or indistinct print, colored or poor quality illustrations and photographs, print bleedthrough, substandard margins, and improper alignment can adversely affect reproduction.

In the unlikely event that the author did not send UMI a complete manuscript and there are missing pages, these will be noted. Also, if unauthorized copyright material had to be removed, a note will indicate the deletion.

Oversize materials (e.g., maps, drawings, charts) are reproduced by sectioning the original, beginning at the upper left-hand corner and continuing from left to right in equal sections with small overlaps. Each original is also photographed in one exposure and is included in reduced form at the back of the book.

Photographs included in the original manuscript have been reproduced xerographically in this copy. Higher quality $6^{\prime \prime} \times 9^{\prime \prime}$ black and white photographic prints are available for any photographs or illustrations appearing in this copy for an additional charge. Contact UMI directly to order.

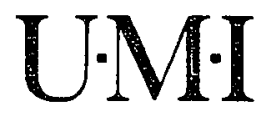

University Microfilms International

A Bell \& Howell Information Company 
Order Number 1958180

Characterization of rare plant habitat for restoration in the San Bernardino National Forest

Gonella, Michael Paul, M.S.

San Jose State University, 1994

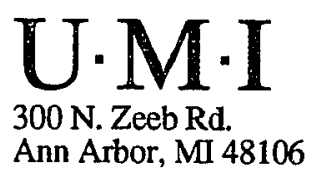




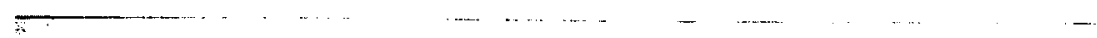




\title{
CHARACTERIZATION OF RARE PLANT HABITAT \\ FOR RESTORATION IN THE SAN BERNARDINO NATIONAL FOREST
}

\author{
A Thesis Presented to \\ The Department of Geography and Environmental Studies \\ San José State University
}

In Partial Fulfillment

Of the Requirements for the Degree

Master of Science

By

Michael P. Gonella

May, 1994 
(C)

Michael Paul Gonella

ALL RIGHTS RESERVED 
APPROVED FOR THE DEPARTMENT OF GEOGRAPHY AND ENVIRONMENTAL STUDIES

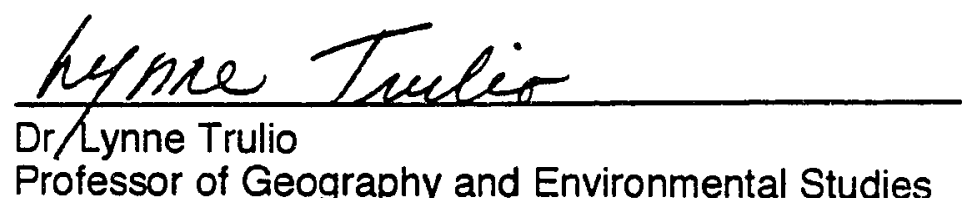

Professor of Geography and Environmental Studies
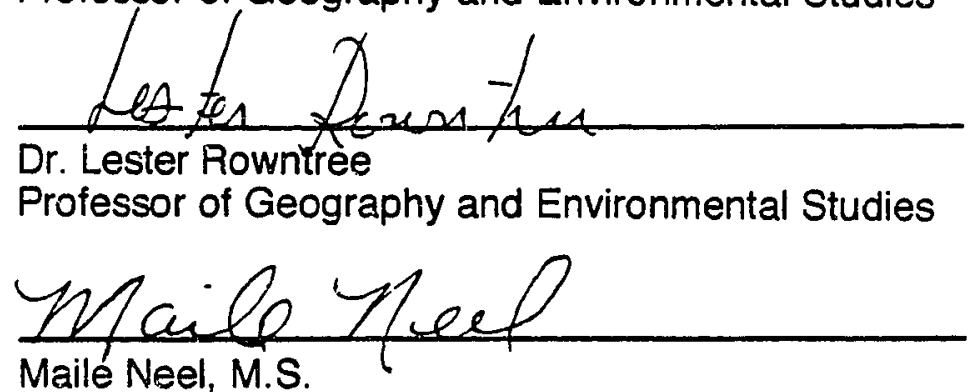

Botanist, U.S.D.A. Forest Service

APPROVED FOR THE UNIVERSITY

Mh Sou OLewandrurate 


\title{
ABSTRACT \\ CHARACTERIZATION OF RARE PLANT HABITAT FOR RESTORATION IN THE SAN BERNARDINO NATIONAL FOREST
}

\author{
By Michael P. Gonella
}

Two herbaceous plant species, the Cushenbury milkvetch (Astragalus albens) and the Cushenbury buckwheat (Eriogonum ovalifolium ssp. vineum) are distributed on carbonate substrates in the San Bernardino Mountains and are threatened by mining activities. These species are proposed for listing as endangered urider federal law. The purpose of this thesis was to validate the target species carbonate-endemism and characterize their habitats to aid the San Bernardino National Forest in conservation efforts.

Environmental and biological data were gathered on plots in and near target species habitats and these habitats were compared. Both species were restricted to carbonate substrates in the study area and were associated with characteristic and indicator species. Astragalus albens was distributed primarily within Blackbrush Scrub, Piñon-Juniper Woodland with Blackbrush, and Piñon-Juniper Woodland with Flannelbush vegetation types, while Eriogonum ovalifolium ssp. vineum was distributed primarily within PiñonJuniper Woodland with Flannelbush and Piñon-Juniper Wocdland vegetation types. 


\section{ACKNOWLEDGMENTS}

I would like to thank those persons assisting me in each part of this thesis. For guidance, review and inspiration during writing this thesis, I thank my committee chairperson Dr. Lynne Trulio at San José State University. I also thank Dr. Lester Rowntree at San José State University for help on my proposal and review of thesis drafts. For proofreading my first draft, I thank Robin Butler of the U.S.D.A. Forest Service. I would also like to thank Jody Sawasaki, Becky Yahr, Dirk Rodriguez, Greg Westlund, Laurel Arnseth, Tony Mann and Tony Cario from the San Bernardino National Forest's Big Bear Ranger Disrict, for assisting in field data collection. Andrew Sanders of the U.C. Riverside Herbarium deserves acknowledgement for helping in plant species identification, as well as Rachel Shea, Lisa Underwood, Kelly Thornburgh, Tony Tur, also at Big Bear, for data entry. For assisting in data analysis I thank Mark Borchert of the Los Padres National Forest and Jenny Rechel of the U.S.D.A. Forest Service Fire Laboratory in Riverside, California. Funding provided by the San Francisco Foundation's Switzer Fellowship and the U.S.D.A. Forest Service were much appreciated.

A very special acknowledgment goes to Maile Neel of the San Bernardino Nationai Forest's Big Bear Ranger District, whose guidance, support and comraderie during most aspects of this thesis were indispensable and greatly appreciated. 


\section{CONTENTS}

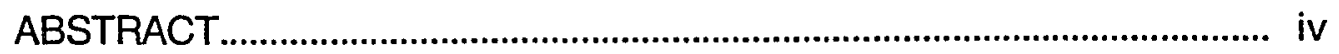

ACKNOWLEGMENTS....................................................................... v

LIST OF TABLES............................................................................... vii

LIST OF FIGURES............................................................................. ix

CHAPTER1

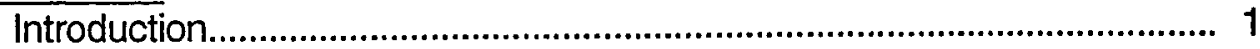

Study Area........................................................................................ 11

CHAPTER 2

Sampling Methods............................................................................. 14

Sampling Design............................................................................... 14

Plot Selection................................................................................ 14

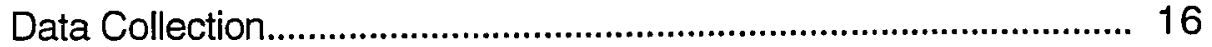

Analytical Methods.................................................................................. 18

Comparisons Between Stratifications....................................... 18

Association of Target Species with Vegetation Types................. 20

Description of Vegetation Types.................................................. 20

\section{CHAPTER 3}

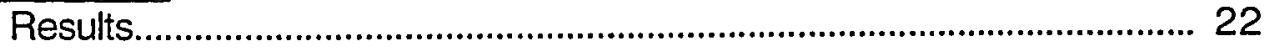

Correlations with Environmental Variables................................. 22

Comparison of Stratifications........................................................ 26

Vegetation Type (VT) Classification............................................ 49

VTs Associated with Astragalus albens..................................... 55

VTs Associated with Eriogonum ovalifolium ssp. vineum........... 55

Description of VTs Associated with the Target Species.............. 58

Description of VTs Not Associated with the Target Species........ 64

CHAPTER 4

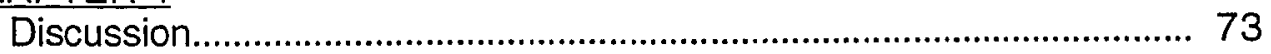

Stratification Comparisons....................................................... 74

Implications for Conservation and Restoration............................ 79

Limitations of Findings............................................................... 82

Summary and Conclusions................................................. 84

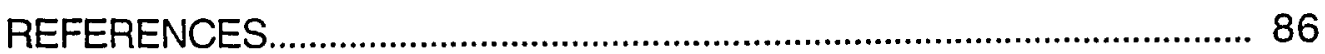

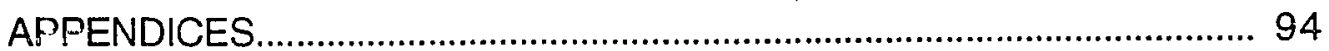




\section{LIST OF TABLES}

1. Cover class categories

2. Relative abundance class categories

3. Ordination scores of environmental variables 23

4. Species richness in carbonate and non-carbonate sites 29

5. Environmental variable values in carbonate and non-carbonate sites

6. Species characteristic of carbonate sites

7. Species characteristic of non-carbonate sites

8. Species richness in sites occupied by $A$. althens and in carbonate sites unoccupied by $A$. albens

9. Environmental variable values in sites occupied by $A$. albens and in carbonate sites unoccupied by $A$. albers

10. Species characteristic of sites occupied by $A$. albens

11. Species characteristic of carbonate sites unoccupied by A. albens

12. Species richness in sites occupied by $E$. o. ssp. vineum and in carbonate sites unoccupied by $E$. o. ssp. vineum

13. Environmental variable values in sites occupied by $E$. 0 . ssp. vineum and in carbonate sites unoccupied by $E$. 0 . ssp. vineum

14. Species characteristic of sites occupied by E. o. ssp. vineum

15. Species characteristic of carbonate sites unoccupied by $E$. o. ssp.vineum

16. Affiliation of vegetation types with substrate types

17. Dominant and indicator species of vegetation types associated with $A$. albens and $E$. O. ssp. vineum

18. Physical characteristics of vegetation types associated with A. albens and $E$. O. ssp. vineum

19. Soil features of vegetation types associated with $A$. albens and E. o. ssp.vineum

20. Environmental features of vegetation types associated with $A$. albens and E. O. ssp. vineum

21. Species richness in vegetation types associated with

$A$. albens and $E$. o. ssp. vineum

22. Structural features of vegetation types associated with $A$. albens and $E$. o. ssp. vineum

23. Dominant and indicator species of vegetation types not associated with $A$. albens and $E$. o. ssp. vineum

24. Physical characteristics of vegetation types not associated with $A$. albens and $E$. o. ssp. vineum

25. Soil features of vegetation types not associated with $A$. albens and $E$. o. ssp. vineum

26. Environmental features of vegetation types not associated with $A$. albens and $E$. o. ssp.vineum 


\section{LIST OF TABLES (Continued)}

27. Species richness in vegetation types not associated with $A$. albens and $E$. o. ssp. vineum

28. Structural features of vegetation types not associated with 


\section{LIST OF FIGURES}

1. Big Bear Ranger District on the San Bernardino National Forest 3

2. Carbonate deposits on the Big Bear Ranger District

3. Target species populations on the Big Bear Ranger District

4. Illustrations of $A$. albens and $E$. o. ssp. vineum

5. Study area location on the Big Bear Ranger District

6. Correlation of elevation and DCA Axis 1

7. Correlation of percentage soil calcium and DCA Axis 2

8. Ordination of carbonate and non-carbonate plots

9. Ordination of $A$. albens plots and carbonate plots unoccupied by $A$. albens

10. Ordination of E. o. ssp. vineum plots and carbonate piots unoccupied by $E$. 0 . ssp. vineum

11. TWINSPAN vegetation classification and vegetation types

12. North-slope profile and general location of vegetation types

13. A. albens occurrences among vegetation types

14. E. o. ssp.vineum occurrences among vegetation types 


\section{CHAPTER 1}

\section{Introduction}

The increasing extent of plant species endangerment in the United States has been well documented (Yablokov and Ostroumov 1991; U.S. Fish and Wildife Service 1991; Center for Plant Conservation 1988; Davis et al. 1986). In the U.S., approximately 2000 plant species, or $10 \%$ of the total U.S. flora, have recently become endangered or extinct and approximately 745 species, or $37 \%$ of California's total native flora are at critical risk of endangerment (Falk 1992). Anthropogenic factors leading to plant species endangerment are many, including habitat destruction, habitat fragmentation, competition from exotics, overgrazing and fire suppression (Falk 1992).

Habitat destruction and fragmentation are perhaps the leading causes of plant species endangerment in the United States (Harris and Silva-Lopez 1992; Falk 1992). Both processes decrease chances of species survival by reducing genetic diversity and associative integrity of plant communities through insularization, population size reduction, and direct removal of individual species (Lewin 1989). These effects are particularly threatening to naturally restricted species whose population numbers and genetic pool are already relatively compromised (Carroll 1992). Consequently, the largest numbers of threatened and endangered species are found in areas where there are both large numbers of endemic species and intense human pressures that result in 
large-scale habitat destruction and modification (Yablokov and Ostroumov 1991; Davis et al. 1986; Smith and Berg 1988).

Mining activities, particularly open pit mining, are among the most severe sources of fragmentation, often resulting in complete destruction of all vegetation, including rare and common species, the seed bank, and soil profile (MacMahon 1987). Effects of habitat fragmentation from open pit mining for carbonate deposits in the relatively arid ecosystems of San Bernardino National Forest (SBNF; Figure 1) are particularly significant because primary productivity is low, soils are thin, and the natural recovery of vegetation after disturbance is extremely slow (Rowlands 1980). Much habitat destruction and fragmentation has already occurred on the north slope of the Big Bear Ranger District (BBRD) of the SBNF where limestone deposits are centered, including the habitat of five rare, herbaceous, carbonate-endemic plant species which are proposed for listing under the Federal Endangered Species Act of 1973 (16 U.S.C. 1531 et seq.; Figure $2 \& 3$ ). Acres of habitat and populations of four of these species have already been lost due to open pit mining on lands managed by the SBNF. Two of the rare carbonate-endemic plants, Cushenbury milkvetch (Astragalus albens) and Cushenbury buckwheat (Eriogonum ovalifolium ssp.vineum), continue to be at risk from open pit mining and are the focus of this thesis (Figure 4).

Because of the continuing threats and impending endangerment to the habitat of the target species, the goal of this thesis was to discover vegetational and environmental features distinguishing target species habitat from surrounding carbonate and non-carbonate habitats, for use in the conservation of remaining populations. To achieve this goal, this thesis tested four 


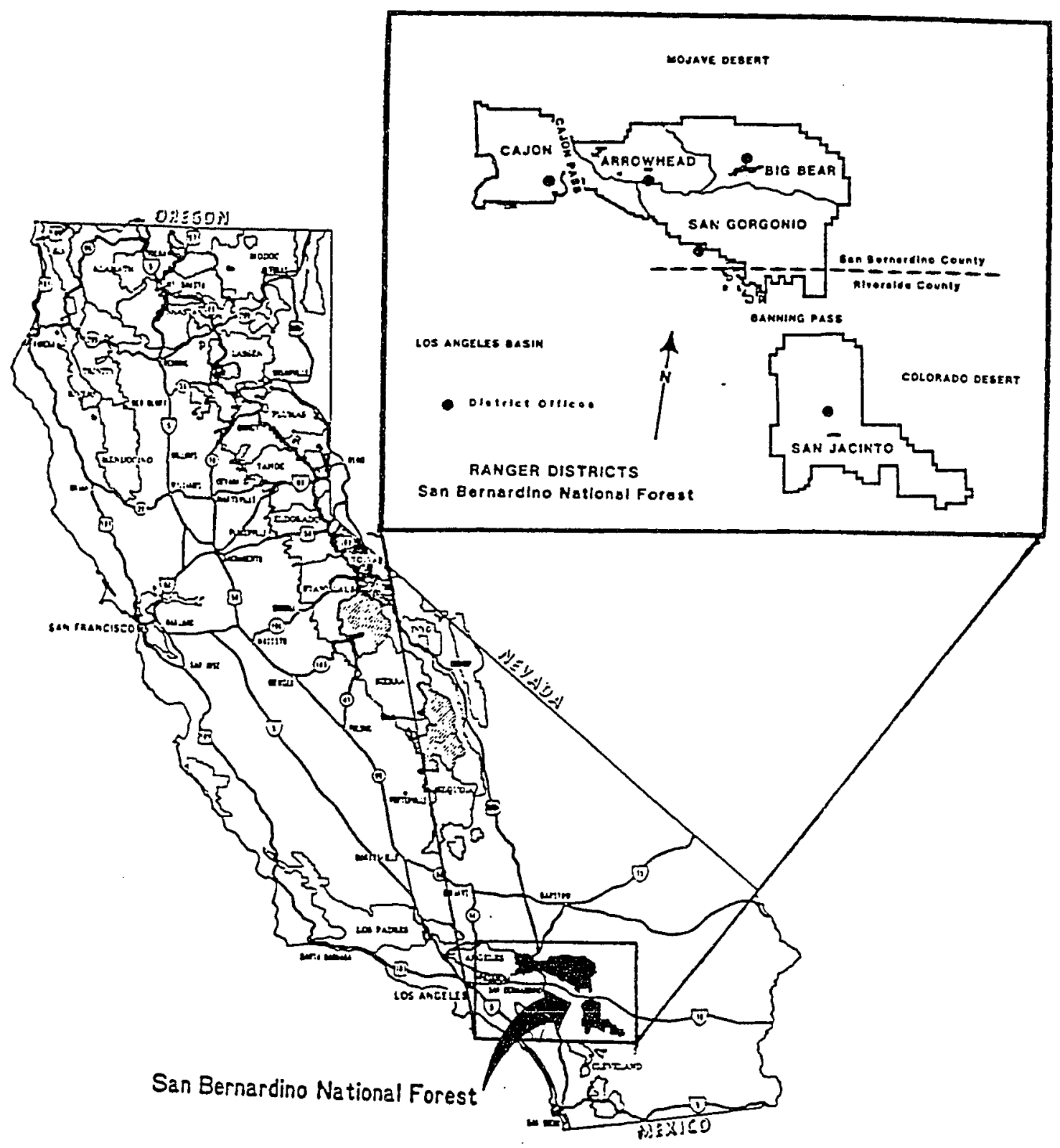

Figure 1: The Big Bear Bear Ranger District on the San Bernardino National Forest in California. 


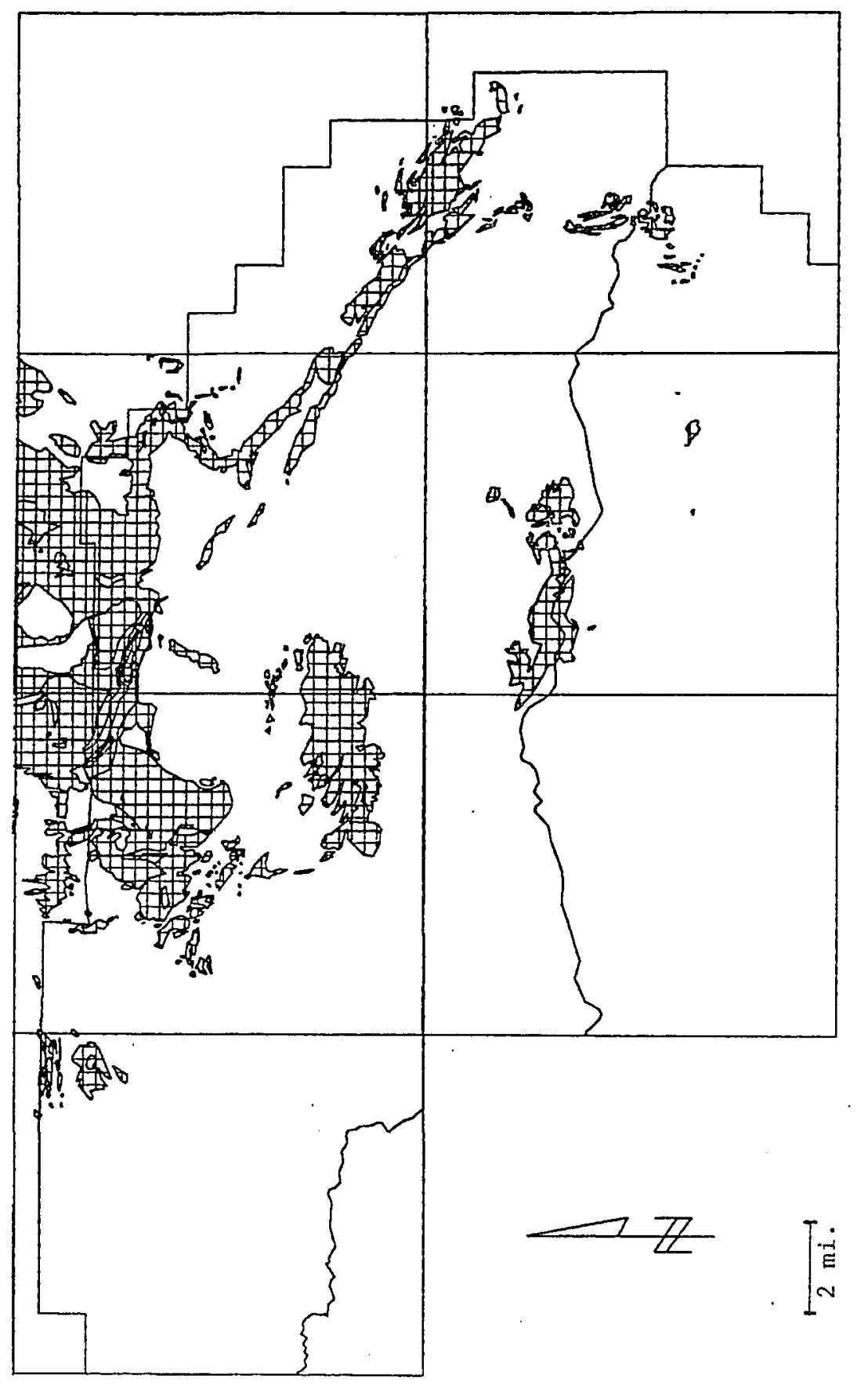

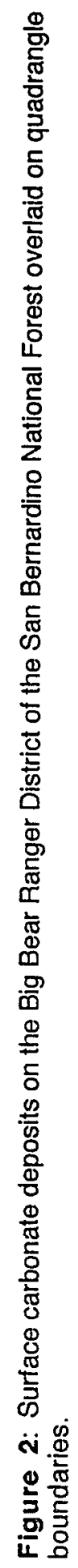



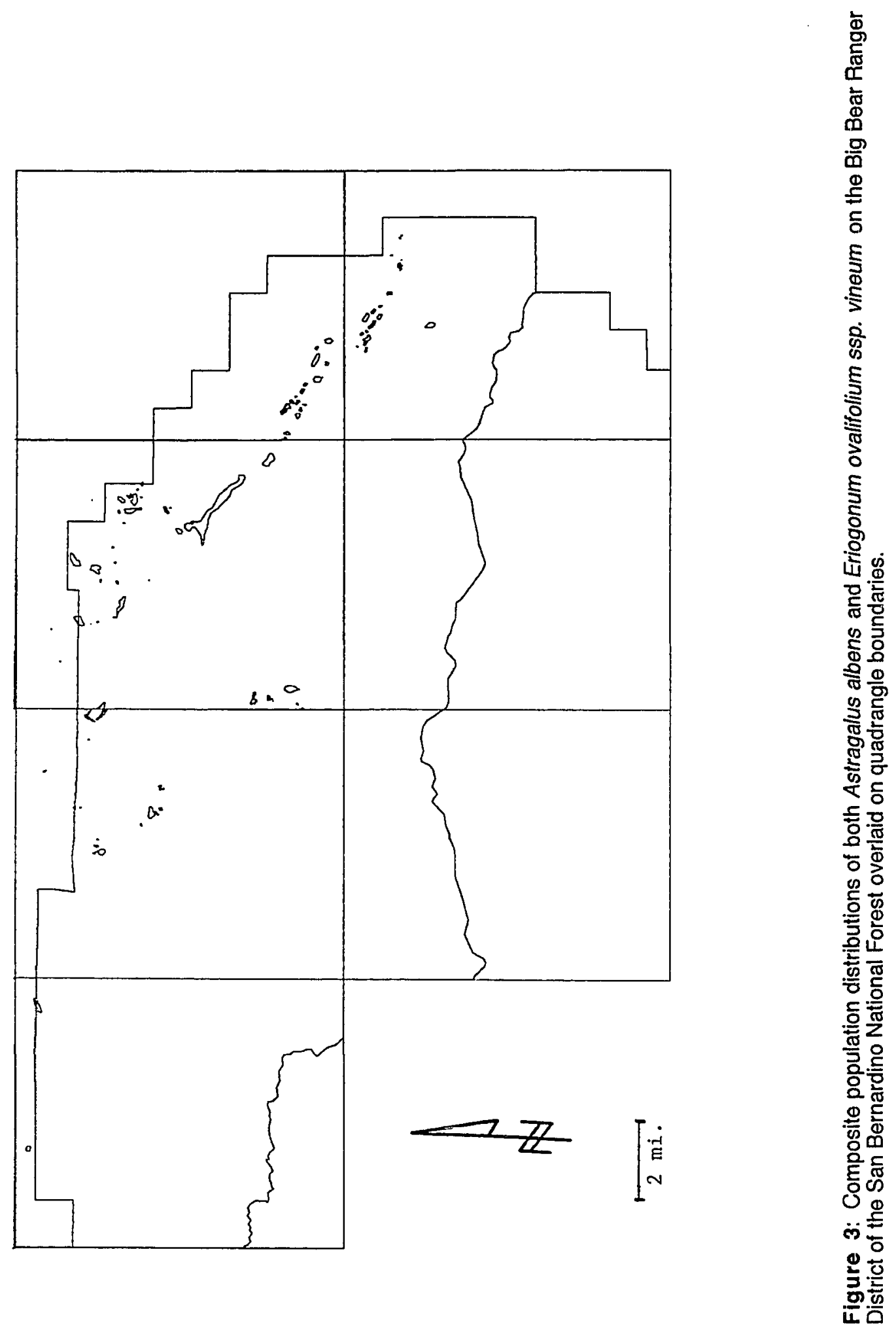


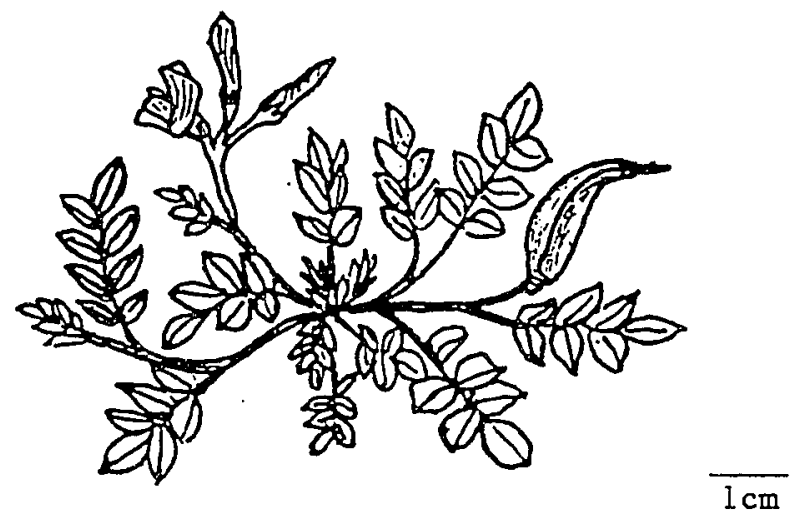

Astragalus albens

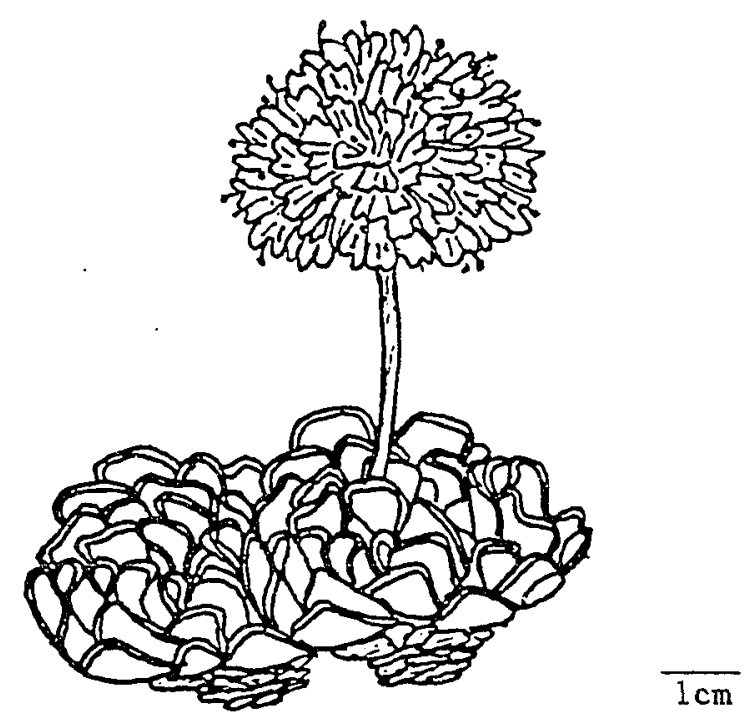

Eriogonum ovalifolium ssp.vineum

Figure 4: Illustrations of Cushenbury's milkvetch (Astragalus albens) and Cushenbury's buckwheat (Eriogonum ovalifolium ssp. vineum; to scale). 
hypotheses. First, because there is evidence that these species are carbonateendemics, this thesis tested whether carbonate-endemism was supported in the study area. Thus, the null hypothesis that the target species were not restricted to carbonate substrates in the study area was tested. This hypothesis was based on previous field research in the study area which indicated the carbonate-endemism of the target species (Barrows 1992; Krantz 1992; Thorne 1992). Validation of the carbonate-endemism of the target species is important, since carbonate-mining companies on the BBRD, holding mining claims on all carbonate deposits in the study area, have repeatedly argued that the target species are not restricted to carbonate surface deposits (Shumway 1992; Brown 1992; Johnson 1992).

The second null hypothesis was that there were no significant vegetational differences and environmental differences between carbonate and non-carbonate sites in the study area. The purpose of this hypothesis was to discern further differences between carbonate-based habitats associated with the target species and non-carbonate based habitats not associated with the target species. This hypothesis was partially based upon qualitative field observations in the study area indicating that vegetation on carbonate substrates, such as limestone and dolomite, is different in species composition and structure than on non-carbonate substrates, such as granite and quartzmonzonite (Neel 1993; Barrows 1988; Krantz 1979).

The third and fourth null hypotheses were that there were no significant environmental and vegetational differences between carbonate sites occupied by the target species and carbonate sites unoccupied by the target species. These hypotheses aimed to discover whether the target species were restricted 
not only to carbonate substrates, but also to a unique subset of carbonate sites within all the available carbonate-based sites in the study area. These hypotheses were partly based upon qualitative field observations in the study area documenting the presence of a few herbs whose distribution appears correlated to the target species, and suggesting a distinctive vegetational community associated with the target species (Neel 1993; Barrows 1988; Krantz 1979).

Specifically, these hypotheses were tested using the following objectives:

1) Compare vegetational and environmental characteristics of carbonate and non-carbonate substrates sites.

2) Compare vegetational and environmental characteristics of sites occupied by $A$. albens and carbonate substrates sites unoccupied by $A$. albens.

3) Compare vegetational and environmental characteristics of sites occupied by E. o. ssp.vineurn, and carbonate substrates sites unoccupied by $E$. o. ssp.vineum.

4) Describe vegetation types on the north slope of the San Bernardino Mountains associated with the target species.

Characteristics unique to the target species and/or surrounding sites were gleaned primarily from the three comparisons. These findings were supplemented with information from the vegetation type description and both were used to test the four hypotheses. 
Specific differences between sites were examined by comparing vegetational and environmental parameters. Vegetational differences found in comparisons were examined primarily by determining characteristic and indicator species. An ecosystem approach which uses indicator species and habitat characterization is the current direction of National Forest policy (The Wilderness Society 1986). In addition, the National Biological Survey is attempting to identify sensitive and rare communities rather than just particular species. By using these integrated approaches, rare species as well as the communities upon which they depend will be protected.

Characteristic and indicator species have specific applications in habitat restoration and in the preservation of rare species such as the Cushenbury milkvetch and the Cushenbury buckwheat. Characteristic species can serve as indicators of the suitability of restored habitat for target species introductions or reintroductions. This could be important when restoration plans need to be initiated immediately, and when target species' seed is rare, gathering untimely, or regulations limit seed collecting and propagation.

Characteristic and indicator species also aid in the recognition of suitable but unoccupied habitat, which may become important if the land on which the target species currently exist is difficult to protect and introductions into new areas become necessary. These species may serve as indicators of environmental stress prior to expression of stress in the target species. Characteristic and indicator species may be involved in ecological functions necessary for the target species establishment and survival.

Specific differences between sites supporting and not supporting the target species were also examined by conducting a classification of vegetation 
in the study area using TWINSPAN (Hill 1979a) and by describing vegetation types associated with the target species. One series-level vegetation classification including the San Bernardino Mountain's north slope has been conducted, to date, but was not specific enough to address vegetation types nor habitat characteristics of the target species (Küchler 1977). The vegetation classification presented in this thesis was also conducted as the first step towards mapping of vegetation on the BBRD, including the north slope, by geographic information systems (GIS), and determination of sites appropriate for target species refugia.

Finaliy, correlations between vegetational and environmental data, and ordination of vegetational data using DECORANA (Hill, 1979b) were used to search for environmental gradients possibly influencing the vegetational differences observed between non-carbonate sites, sites occupied by the two target species and carbonate sites unoccupied by the two target species. 


\section{Study Area}

The study area occurs within a 40-square-mile area of the SBNF's Big Bear Ranger District (BBRD) and is restricted to the north and northeast slopes of the San Bernardino Mountains (Figure 5). Carbonate deposits on the BBRD, mapped by Geo/Resource Consultants, Inc. in 1981 and by Howard Brown in 1992, were divided into nine units distinguished by both topographic and management criteria. Four of the nine units containing the largest number of target species populations were the focus of this study: Helendale, Blackhawk, The Islands, and Marble Canyon (Appendices 1-4). In general, these units were composed of shallow, erodible soils covering rocky hills and valleys, and talus covering steeper slopes. These four units and adjacent non-carbonate substrate soils made up the study area. The study area's vegetation is sirongly influenced by the adjoining Mojave Desert, and was comprised principally of a Piñon-Juniper Woodland at higher elevations (1500-2500m), and Joshua Tree Woodland (750-1200m) and Blackbrush scrub, dominated by Coleogyne ramosissima, at lower elevations (1000-2000m; Munz and Keck 1959).

Mean precipitation, as recorded at the lower end of the study area in Lucerne Valley, is $104 \mathrm{~mm} /$ year, with $20 \%$ of the precipitation falling in the summer months (Bauder and Larigauderie 1991). For the upper end of the study area in Big Bear City, this figure is $382 \mathrm{~mm} / \mathrm{year}$, with $19 \%$ summer precipitation. Precipitation figures for the study area vicinity, including Lone Valley, Blackhawk Mountain and areas west of Cushenbury Grade on State Highway 18 fall between these two figures (SBNF Big Bear Ranger District 


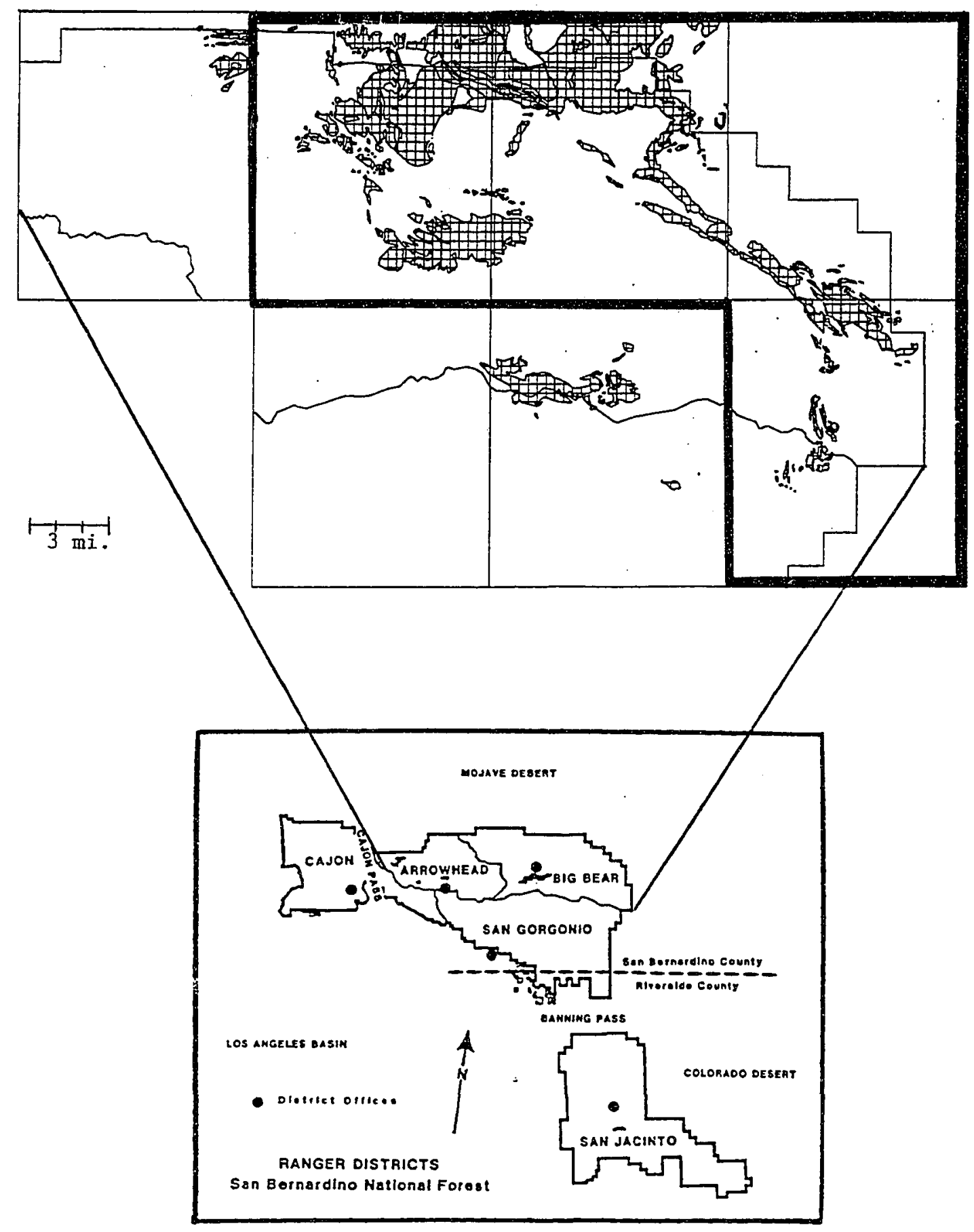

Figure 5: Study area on the Big Bear Ranger District of the San Bernardino National Forest. 
Records 1991). Mean temperatures in the Lucerne Valley range from 6.8 degrees $C$ in January to 27.7 degrees $C$ in July (Bauder and Larigauderie 1991) and from -1.4 degrees $C$ in January to 15.0 degrees $C$ in July in Big Bear City (SBNF Big Bear Ranger District Records 1991). Mean temperatures of the study area were assumed to fall within these two ranges (SBNF Big Bear Ranger District Records 1950-1990). 


\section{CHAPTER 2}

\section{Methods}

\section{Sampling Design}

To compare and describe vegetational and environmental characteristics of non-carbonate sites, carbonate sites not supporting the target species and sites supporting the target species, I divided the study area into four stratifications, as follows:

1) Sites occupied by A. albens.

2) Sites occupied by E. o. ssp. vineum

3) Carbonate substrate sites, including 1) and 2).

4) Non-carbonate substrate sites.

Plot Selection

Plots were selected within the four stratifications, as follows:

1) Carbonate plots ( $n=88$ ): Within each cadastral section, percentage cover of carbonate surface deposit was calculated within each section containing 
more than $5 \%$ coverage, two random points were selected within mapped carbonate deposits. Each random point served as the center of a 0.04 hectare plot. Sections containing less than $5 \%$ carbonate cover were excluded from sampling for ease of field location and to reduce effects of carbonate/non-carbonate transitional soils.

2) Non-carbonate plots $(n=73)$ : Within each section containing carbonate substrate plots, two random points were selected on non-carbonate substrates. Each non-carbonate plot center was at least $200 \mathrm{~m}$ from any carbonate deposit boundary. If sections contained no non-carbonate substrate, non-carbonate plots were selected from adjacent sections.

3) A. Albens-centered plots $(n=30)$ : One to two random plots were located within each section containing an $A$. albens population. As new populations were found during the progression of sampling, new plots were added. An arbitrary density of $20 \mathrm{~A}$. albens plants was selected as the minimum density for $A$. albens-centered plots.

4) E. o. ssp. vineum-centered plots $(n=28)$ : One to two random plots were located within each section containing a target species population. As new populations were found during the progression of sampling, new plots were added. An arbitrary density of 15 E. o. ssp.vineum plants was selected as the minimum density for E. o. ssp. vineum-centered plot. 


\section{Data Collection}

Each random point served as the center of a 0.04 hectare circular plot. Within each plot, aspect, slope, and elevation were measured using a compass, clinometer and topographic maps, respectively. A northness index was calculated as, sin(slope in degrees) $\times \cos$ (aspect in degrees). A soil sample was taken at depths ranging from $0-45 \mathrm{~cm}$ (as allowed by soil depth) and $\mathrm{pH}$ was determined. Percentage of total calcium and magnesium from soil extracts were determined by Babcock Laboratories in Piverside, California. Percentage of geologic cover was estimated by categories classes (Table 1) in 1992 and by actual cover in 1993 for nine size categories including outcrop, boulder, rock, cobble, gravel, soil, and litter.

All overstory and shrub layer species were listed and their percentage cover of the plot estimated by relative categories in 1992 (Table 1). Cover estimation methods were changed from use of categories in 1992 to use of actual cover in 1993, for greater precision. Height $(m)$ and diameter at breast height $(\mathrm{DBH} ; \mathrm{cm})$ of main trunks of each overstory species were measured using a clinometer and a DBH tape, respectively. Within the herb layer, all species were listed and species abundances were estimated using a relative

scale (Goldsmith 1991; Table 2). Densities of the target species and Oxytheca parishii var. goodmaniana and Erigeron parishii were determined. Species identification and nomenclature followed that of Munz (1974) for all genera except Crypiantha and Phacelia which followed Hickman (1993). 
Table 1: Cover class category criteria.

\begin{tabular}{cl}
\hline Cover Class & Percentage Cover \\
\hline 0 & $0 \%$ cover \\
1 & Trace $(<\%$ cover \& <3 plants) \\
2 & Trace-1\% (<1\% cover \& $>3$ plarts) \\
3 & $1-5 \%$ \\
4 & $5-10 \%$ \\
5 & $10-25 \%$ \\
6 & $25-50 \%$ \\
7 & $50-75 \%$ \\
8 & $75-95 \%$ \\
9 & $95-100 \%$ \\
\hline
\end{tabular}

Table 2: Relative abundance class categories

\begin{tabular}{ll}
\hline Class & Criteria \\
\hline Rare(R) & $1-5$ plants in plot \\
Occasional (O) & $>5$ plants, localized within one are within plot \\
Frequent (F) & Plants found in $>1$, or in one extended area in plot \\
Abundant (A) & Found evenly throughout, but not dominant in plot \\
Dominant (D) & Dominant throughout plot; includes cover factor \\
\hline
\end{tabular}




\begin{abstract}
ANALYSIS
Comparisons Between Stratifications

Three separate stratification comparisons were conducted: 1) all carbonate sites ( $\underline{n}=146$; which included all randomly selected carbonate plots $(\underline{n}=88)$ and all target species-centered plots $(\underline{n}=58))$ versus all non-carbonate sites.carbonate sites, 2) sites occupied by $A$. albens $(\underline{n}=30)$ versus unoccupied carbonate sites ( $\underline{n}=79$, excluding carbonate plots containing $A$. albens), and 3 ) sites occupied by $E$. 0 . ssp. vineum $(\underline{n}=28)$ versus unoccupied carbonate sites (n=66, excluding carbonate plots containing E. o. ssp.vineum).

The occurrence of target species among carbonate and non-carbonate plots was first examined by tabular analysis. Second, comparisons of total species richness, vegetation layer richness, exclusive species and common species were made using equal plot numbers from each stratification (Goldsmith 1991; Magurran 1988). Mean species richness comparisons were made using all plots in each stratification. The Kruskal-Waliis ANOVA was used to compare the means of all environmental and vegetational variables between the stratifications, in all three comparisons. Differences in environmental and vegetational means between the stratifications were considered significant when the probability of the differences being due to random chance $(\mathrm{p})$ was less than 0.01 and the critical value of the Kruskal-Wallis statistic $(\underline{H})$ was greater than 6.64 .
\end{abstract}


Third, dominant, characteristic and indicator species were determined. Dominant species were those overstory species with mean covers greater than $5 \%$, and shrub and bunchgrass species with mean covers greater than $3 \%$. Characteristic species were those with significant differences in cover or abundance between the two stratifications (from the Kruskal-Wallis ANOVA), and high fidelity (greater than $80 \%$ of occurrences within one stratification) or high constancy (occurred in more than $25 \%$ of plots in the stratification). Indicator species were the same as characteristic species except that they had both high fidelity and high constancy.

Finally, an exploration of environmental relationships among plots, and stratifications was conducted using detrended correspondence analysis (DECORANA or DCA), an indirect ordination technique (Hill 1979b). Species present in less than 5 plots were excluded from DECORANA analysis. Correlations between the environmental variables $\mathrm{pH}$, percentage calcium and magnesium in extract, elevation, northness, slope, percentage geologic cover), and all other variables, including DCA scores, percentage cover for overstory, shrub, and perennial bunchgrass species, relative abundances for perennial bunchgrass and herb species, densities of target species, mean species richness, species diversity (Shannon's diversity index), total overstory cover, total shrub cover, canopy height, and overstory DBH, were examined using simple linear correlation (Pearson $\mathfrak{r}$ ). Relationships with correlation coefficients (1) greater than 0.40 were reported. Relationships were considered meaningful where $\underline{r}$ was greater or equal to 0.55 and the probability of the relationship being due to random chance $(\mathrm{p})$ was less than 0.01 . 
Association of Target Species with Vegetation Types

Two-way indicator species analysis (TWINSPAN), a hierarchical divisive classification technique, was used to classify the 219 plots and 300 species into vegetation types based on species and pseudo-species associations (Hill 1979a). The number of pseudo-species corresponded to the number of cover class categories for each individual species, across all plots. Pseudo-species cut levels of $0,0.3,1.5,6,15,30,45$, and 75 were chosen. TWINSPAN groups represented by fewer than six plots were either separated out or reintegrated into the most similar larger vegetation types. The two target species were excluded during the analysis as were two other carbonate endemic plant species, Oxytheca parishii var. goodmaniana and Erigeron parishii, to prevent formation of vegetation types due to the associative influences of the carbonateendemic species. Distributions of target species occurrences among the vegetation types was used to determine association of the target species with particular vegetation types.

\section{Description of Vegetation Types}

Descriptions of the VTs associated with the target species included calculation of means and standard deviations of all environmental variables, percentage cover for overstory and shrub species, relative abundances for herb species, densities of target species, species richness, Shannon's diversity index, total overstory cover, total shrub cover, canopy height and overstory DBH 
for each VT. Total species richness was also calculated for each VT. Comprehensive species lists were compiled for four VTs associated with the target species (Appendices 12-15), and for six VTs not associated with the target species (Appendices 16-21).

Descriptions of the VTs associated with the target species also included determination of dominant and indicator species, and mean values for all environmental and vegetational variables. Dominant and indicator species were determined for each VT as follows. Dominants were those overstory species with a mean cover greater than $5 \%$, shrub species mean cover greater than $3 \%$, perennial bunchgrass species mean cover greater than $3 \%$, and perennial bunchgrass and herb species with an abundance greater than 1.0, per VT. Indicator species were those determined by the TWINSPAN analysis or by the method used in stratification comparisons. A higher constancy value $(50 \%)$ than in the stratification comparisons $(25 \%)$ was used in determination of indicators species for VTs, due to the relatively small sample sizes. 


\section{CHAPTER 3}

\section{Results}

\section{Correlation with Environmental Variables}

For the most part, DCA scores were not strongly correlated with environmental variables (Table 3 ). The first DCA Axis was positively correlated to elevation ( $r=0.67, \underline{p}<0.0001$; Figure 6$)$. DCA Axis 1 scores were also positively correlated with percentage litter cover $(r=0.47, \underline{p}<0.0001)$ and negatively correlated to species richness $(r=-0.50, \underline{p}<0.0001)$ but less strongly than elevation. It appeared that the first DCA Axis separated plots along an elevation gradient extending from the relatively species rich (high number of shrub and herb species), litter-free Blackbrush Scrub plant communities at the northern base of the San Bernardino Mountains to the relatively species poor (few shrub and herb species), litter-covered, Yellow Pine Forest at the top of the north slope. These results confirmed previously documented changes in vegetation from the drier, hotter habitats near the desert floor to the cooler, wetter habitats at the top of the north slope (Barbour and Major 1990; Holland 1986; Thorne 1982).

The second gradient influencing the distribution of plant species in the study area was soil calcium content, though the gradient was not as strong as that of elevation ( $\underline{r}=-0.55, \underline{p}<0.0001$; Figure 7 ). A majority of soil samples 
Table 3: Correlation coefficients ( $\mathrm{c}$ ) of all environmental variables, target species densities, species richness and diversity with scores on the first three DCA Axes. An asterisk denotes significant correlations ( $\underline{p}-0.55, \underline{p}<0.01, \underline{\mathrm{n}}=219)$ : Axis 1 was positively correlated with elevation and Axis 2 was negatively correlated with percentage soil calcium. No other correlations were significant.

\begin{tabular}{|c|c|c|c|}
\hline \multirow[b]{2}{*}{ Environmental Variable } & \multicolumn{3}{|c|}{ DCA } \\
\hline & Axis 1 & Axis 2 & Axis 3 \\
\hline $\begin{array}{l}\text { Slope (degrees) } \\
\text { Northness } \\
\text { Elevation (m) } \\
\text { pH } \\
\text { calcium (\% total extract) } \\
\text { magnesium (") } \\
\% \text { Outcrop cover } \\
\% \text { Boulder cover } \\
\% \text { Rock cover } \\
\% \text { Cobble cover } \\
\% \text { Gravel cover } \\
\% \text { Soil cover } \\
\% \text { Litter cover } \\
\text { Density of A. albens } \\
\text { Density of E. o. ssp. vineum } \\
\text { Richness } \\
\text { Shannon's Diversity Index }\end{array}$ & $\begin{array}{r}.16 \\
.04 \\
.67^{*} \\
-.28 \\
-.09 \\
.04 \\
.03 \\
.03 \\
.21 \\
.16 \\
-.09 \\
-.24 \\
.47 \\
-.22 \\
.06 \\
-.50 \\
-.44\end{array}$ & $\begin{array}{l}-.35 \\
-.09 \\
.21 \\
-.36 \\
-.55 \\
-.31 \\
-.13 \\
.11 \\
.03 \\
-.05 \\
.13 \\
.26 \\
.04 \\
-.09 \\
-.22 \\
-.17 \\
-.18\end{array}$ & $\begin{array}{r}.09 \\
-.03 \\
.01 \\
-.37 \\
-.35 \\
-.11 \\
.10 \\
.31 \\
.28 \\
.17 \\
.05 \\
.04 \\
.04 \\
-.09 \\
-.12 \\
-.08 \\
-.03\end{array}$ \\
\hline
\end{tabular}




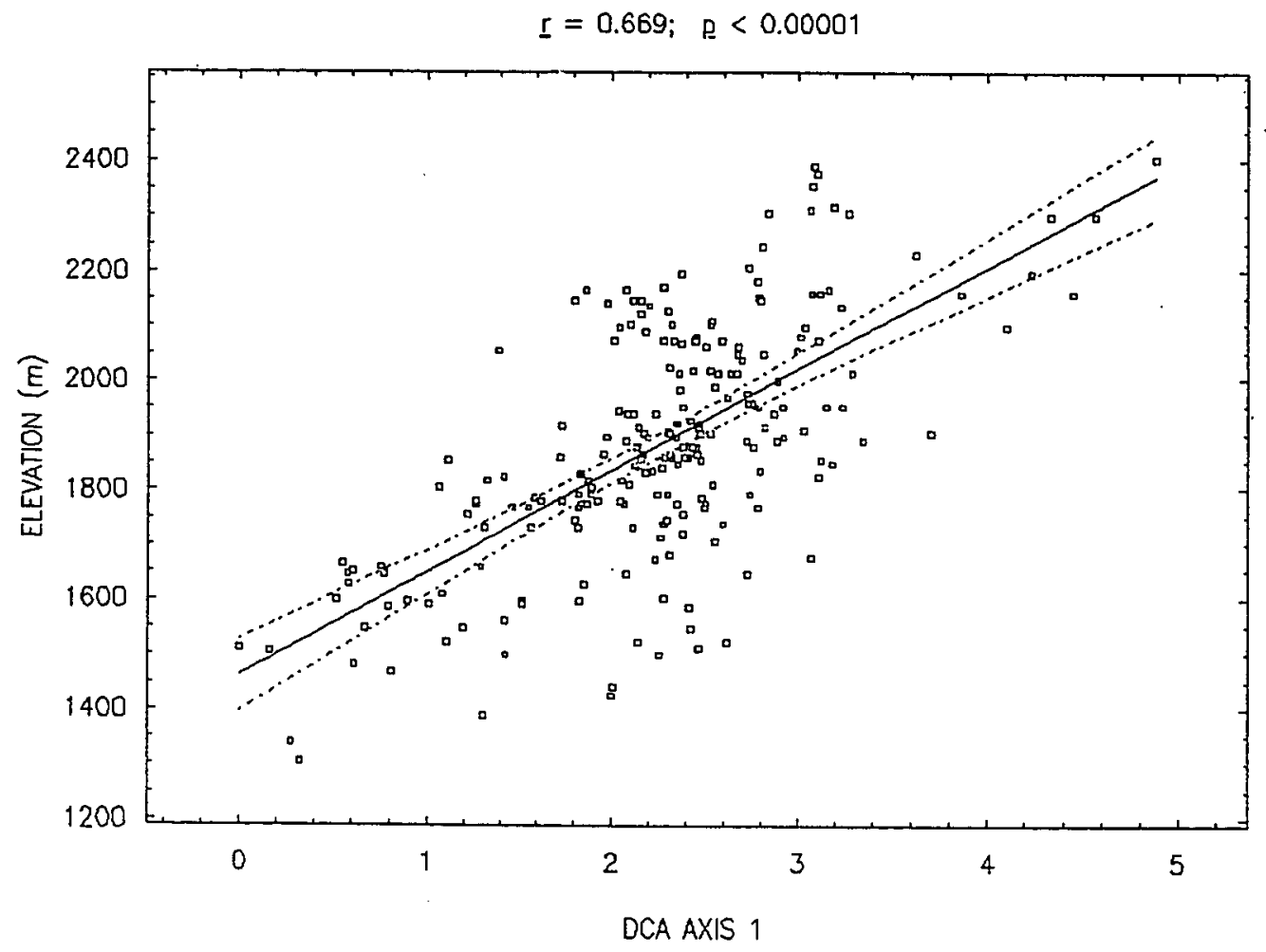

Figure 6: Correlation of elevation and the first DCA Axis for all 219 plots. 


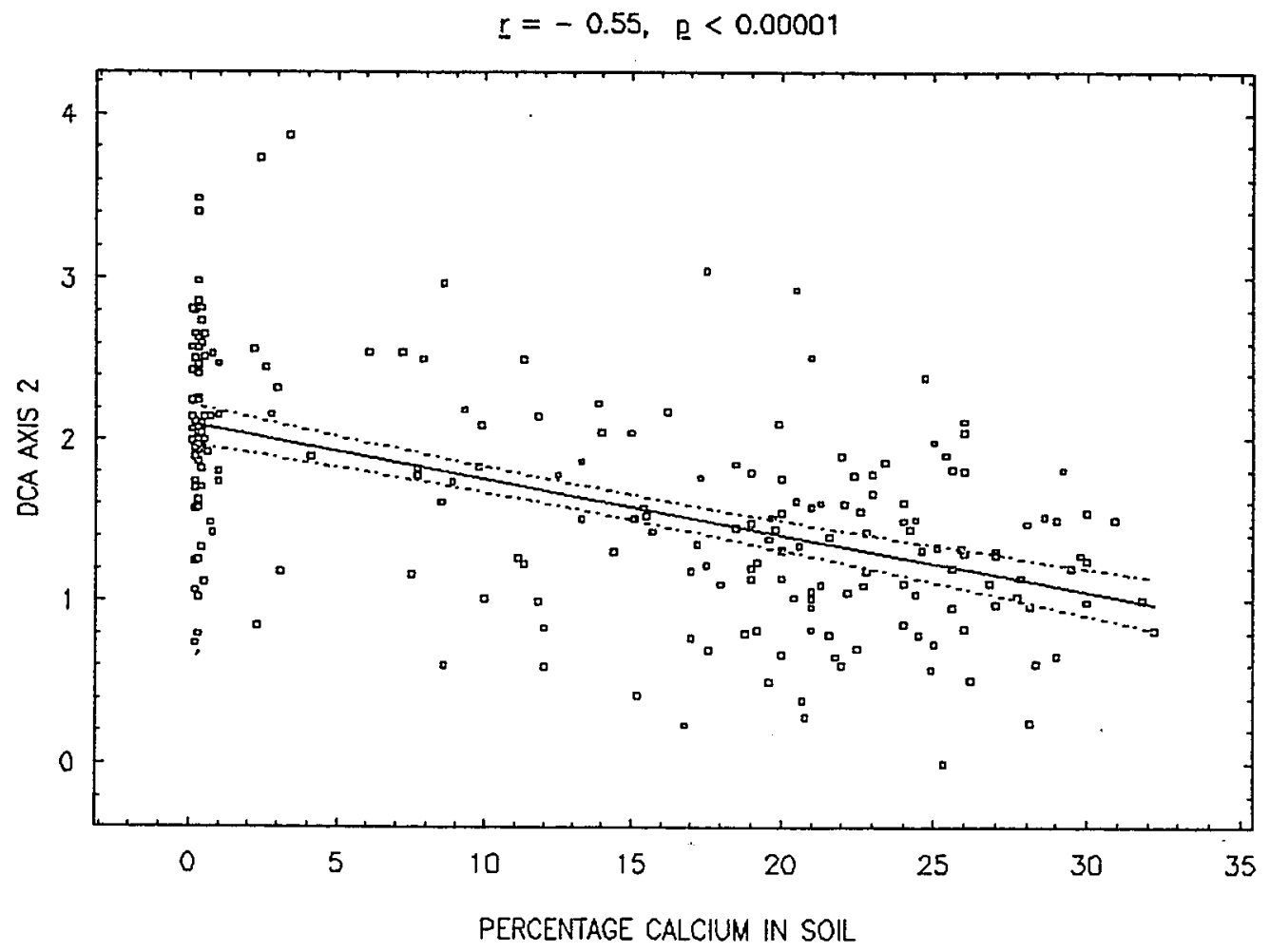

Figure 7: Correlation of percentage soil calcium and the second DCA Axis for all 219 plots. 
analyzed contained either very low ( $<0.5 \%$; non-carbonate) or high $(>15 \%$; carbonate) extractable calcium, while the minority fell in between. For this reason, this gradient said less about gradual vegetational changes as a response to the amount of calcium in the soil than about vegetation differences between carbonate and non-carbonate substrate types. Nevertheless, some plots were positioned in between the extremes aiong the gradient and probably represent species adapted to either carbonate, non-carbonate, or transitional soils.

Comparison of Stratifications

Comparison of Carbonate and Non-Carbonate Sites

No occurrences of target species occurred on non-carbonate substrates in the study area. However, the target species occurred in 2 out of 73 random non-carbonate plots. Soil analysis of these 2 plots showed that both contained a relatively high level of calcium $(7.5 \%$ and $29.8 \%)$ near the range of percentage soil calcium found in carbonate plots containing the target species (8.6\%-32.0\%). These findings stiggest that these sites were, in reality, carbonate substrates that had been mismapped as non-carbonate. In contrast, out of 88 random carbonate plots there were 27 plots containing one of the two target species, or both. Of these 27 plots, 9 plots contained A. albens, and 22 
contained E. o. ssp.vineum. These findings suggested that the target species was present exclusively or nearly so on carbonate substrates in the study area.

Dominant and indicator plant species differeed between carbonate and non-carbonate sites. For example, the presence of Cercocarpus ledifolius or Chrysothamnus viscidiflorus in the shrub layer and Arabis pulchra and Castilleja chromosa in the herb layers generally indicated carbonate sites. In addition, the presence of either of the two target species was a very strong indicator of carbonate sites. On the other hand, the presence of Quercus turbinella in the overstory layer, Artemisia tridentata and Purshia glandulosa in the shrub layer, and Sitanion hystrix in the herb layer generally indicated non-carbonate sites. The presence of five relatively rare overstory species, including, Abies concolor, Pinus jeffreyi, Pinus lambertiana, Populus fremontii, and Salix exigua, observed only on non-carbonate substrates, was also indicative of that substrate. An additional difference was the relatively stunted growth and cover of Juniperus osteosperma (Utah Juniper) on carbonate substrates compared to non-carbonates substrates.

A few physical characteristics were cues of either a carbonate or noncarbonate substrate-based habitats. For example, exposed bluish-white carbonate cliffs and bedrock often contrasted with surrounding non-carbonate areas of generally darker colored bedrock. Carbonate sites were also generally more open, perhaps due to the less tolerable carbonate soil conditions as compared to non-carbonate habitats. In addition, non-carbonate-based habitats often contained a higher cover of granite boulders and a denser mat of litter in the understory than carbonate-based habitats. In many cases the two substrate-based habitats were difficult to distinguish in the field. Howeyer, 
some significant differences in species ricinness, environmental variables, species covers, species abundances, and ordination scores were found between the two stratifications and are discussed below.

A total of 300 species were recorded in the 219 plots sampled during the study. Three-hundred species were also recorded from the 146 randomly selected plots in which each stratification contained 73 plots. One hundred and ninety species were recorded for randomly selected carbonate plots, which included some target species centered plots ( $\underline{n}=73$ ), and 231 were recorded for non-carbonate substrate plots ( $\underline{n}=73 ;$ Table 4$)$. In the randomly selected plots, 151 species were common to both substrates, 68 species were exclusive to carbonate plots which included some plant-centered plots ( $\underline{n}=73$ ), and 110 were exclusive to non-carbonate plots ( $\underline{n}=73$; Appendix $5 \& 6$ ). Greater total richness and greater numbers of exclusive species on non-carbonate than on carbonate substrates were attributed to the wider variety of habitats encountered on non-carbonate substrates. For example, species associated with very high elevation habitats, riparian areas and meadows, were simply not found on carbonate substrates.

Significantly higher total species richness on non-carbonate than on carbonate substrates was found, agreeing with substrate comparisons of vegetation on limestone (carbonate) and granite (non-carbonate) in the Mule Mountains of Arizona, by Wentworth (1981). Twice as many overstory species were observed on non-carbonate substrates as were on carbonate in this thesis. However, each of the overstory species exclusive to non-carbonate substrates were observed very infrequently and were restricted to a relatively rare habitat in the study area (e.g., Pinus jeffreyi in montane habitats). 
Table 4: Total species richness by vegetation layer for carbonate and non-carbonate substrate sites using randomly selected samples of equal size.

\begin{tabular}{lrc}
\hline Species & Carbonate $(n=73)$ & Non-Carbonate $(n=73)$ \\
\hline Overstory & 6 & 12 \\
Shrub & 47 & 57 \\
Herb \& Bunchgrass & 147 & 162 \\
& & \\
Layers Combined & 151 & 151 \\
Common to both samples & 68 & 110 \\
Exclusive to one sample & 190 & 231 \\
Total Richness & & \\
\hline
\end{tabular}


Significant differences between means of environmental variables of carbonate and non-carbonate stratifications included $\mathrm{pH}(\underline{H}=44.22, \underline{\mathrm{p}}<$ $0.00001, \underline{d f}=1)$, percentage calcium in soil $(\underline{H}=102.83, \underline{p}<0.00001, \underline{d f}=1)$, percentage magnesium in soil $(\underline{H}=37.95, \underline{p}<0.00001$, $\underline{d i}=1)$, slope $(\underline{H}=10.92$, $\underline{p}<0.001, \underline{d f}=1)$, percentage gravel cover $(\underline{H}=11.52, \underline{p}<0.001, \underline{d f}=1)$, percentage soil cover $(\underline{H}=26.29, \underline{p}<0.00001, \underline{d f}=1)$, and percentage litter cover $(\underline{H}=7.38, \underline{p}<0.01, \underline{d f}=1 ;$ Table 5). Significant differences between means of species-related variables included percentage cover of 2 overstory species, 15 shrub layer species, and 4 perennial bunchgrass species, relative abundance of 3 perennial bunchgrasses and 31 herb species, and densities the two target species (Appendix 7). Of these, 1 overstory species, 6 shrub species, 4 bunchgrasses and 14 herbs, including both target species, had significantly greater mean values in carbonate sites than in non-carbonate sites. Species characterizing carbonate sites and non-carbonate sites are listed in Tables 6 and 7, respectively. Mean covers and frequencies of species characterizing carbonate sites are listed in Appendix 7.

Ordination provided an interpretable separation of the carbonate and non-carbonate groups along the second DCA Axis. The mean DCA Axis 2 scores of the groups were significantly different $(\underline{H}=58.71, \underline{p}<0.00001, \underline{\mathrm{df}}=1)$ which suggested difference in vegetation between the two substrate types (Figure 8). The non-carbonate group was situated above the non-carbonate group in ordination space and extended further along the first DCA Axis. This accurately reflected the general differences among the plot types in regards to elevation and soil calcium content; carbonate plots were located at low and middle elevation levels and were of relatively high calcium content and non- 


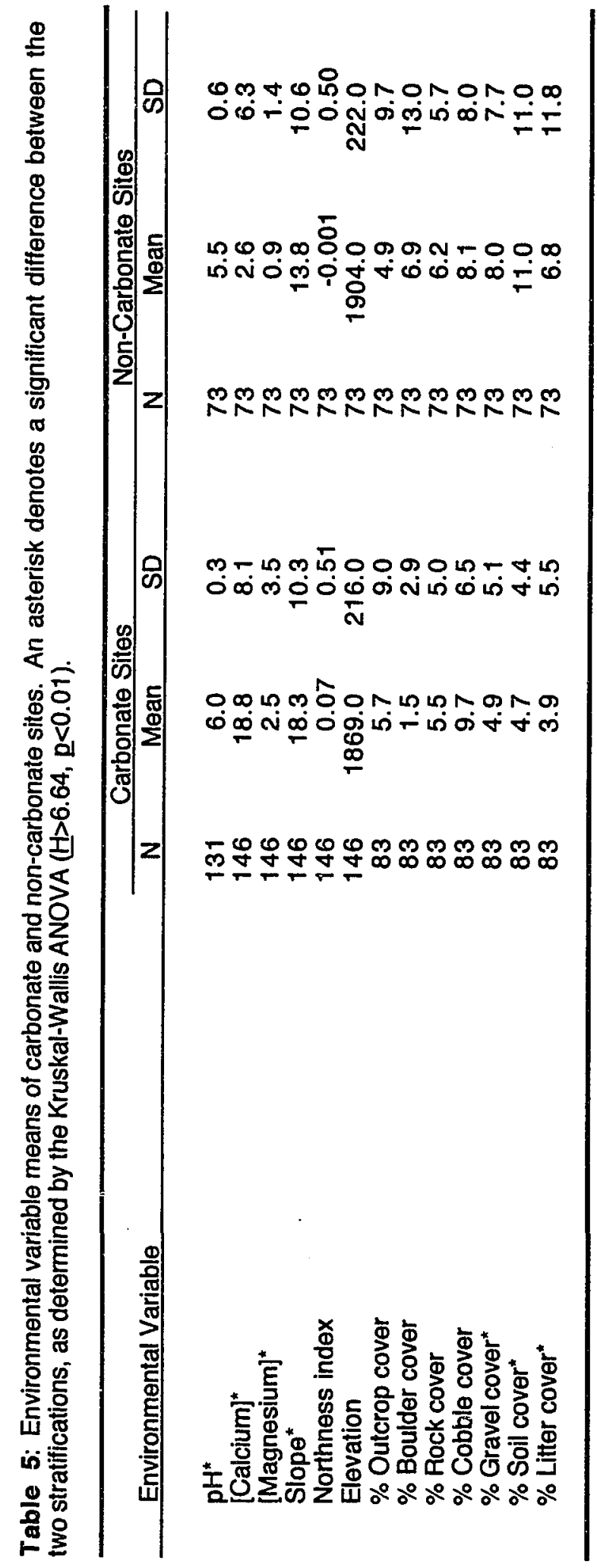


Table 6: Species characterizing carbonate substrates including dominants (d; overstory species: mean cover $>5 \%$, shrub and bunchgrass species: mean cover $>3 \%$ ), species with high fidelity ( $f ;>80 \%$ of species occurrences limited to carbonate plots), species with high constancy (c; present in $>25 \%$ of carbonate plots), and indicator species (i; species with both high fidelity and high constancy).

\begin{tabular}{|c|c|c|}
\hline Vegetation laver & Species & Designation \\
\hline Overstory & $\begin{array}{l}\text { Juniperus osteosperma } \\
\text { Pinus monophylla }\end{array}$ & $\begin{array}{l}d, i \\
d\end{array}$ \\
\hline Shrub & $\begin{array}{l}\text { Arctostaphylos glauca } \\
\text { Cercocarpus ledifolius } \\
\text { Chrysothamnus viscidiflorus ssp. stenophyllus } \\
\text { Ephedra viridis } \\
\text { Eriogonum fasciculatum ssp. polifolium } \\
\text { Eriogonum microthecum var. corymbosoides } \\
\text { Forsellesia nevadensis } \\
\text { Phoradendron bolleanum ssp. densum }\end{array}$ & $\begin{array}{l}\mathbf{d} \\
\mathbf{d}, \mathbf{i} \\
\mathbf{d}, \mathbf{i} \\
\mathbf{f} \\
\mathbf{f} \\
\mathbf{i} \\
\mathbf{f} \\
\mathbf{f}\end{array}$ \\
\hline Bunchgrass & $\begin{array}{l}\text { Oryzopsis hymenoides } \\
\text { Stipa coronata depauperata }\end{array}$ & $i$ \\
\hline Herbs & $\begin{array}{l}\text { Arabis pulchra } \\
\text { Arabis shockleyi } \\
\text { Arenaria macradenia } \\
\text { Astragalus albens } \\
\text { Castilleja chromosa } \\
\text { Cryptantha confertiflora } \\
\text { Eriogonum inflatum } \\
\text { Eriogonum ovalifolium ssp. vineum } \\
\text { Gilia austrooccidentalis } \\
\text { Penstemon eatonii } \\
\text { Phacelia douglasii } \\
\text { Phacelia fremontii } \\
\text { Phlox austromontanum }\end{array}$ & $\begin{array}{l}i \\
i \\
i \\
i \\
i \\
f \\
f \\
i \\
i \\
f \\
f \\
i \\
f\end{array}$ \\
\hline
\end{tabular}


Table 7: Species characterizing non-carbonate substrates including dominants (d; overstory species: mean cover $>5 \%$, shrub and bunchgrass species: mean cover $>3 \%$ ), species with high fidelity ( $f ;>80 \%$ of species occurrences limited to non-carbonate plots), species with high constancy (c; present in $>25 \%$ of non-carbonate plots), and indicator species (i; species with both high fidelity and high constancy).

\begin{tabular}{|c|c|c|}
\hline Vegetation laver & Species & Designation \\
\hline Overstory & $\begin{array}{l}\text { Pinus monophylla } \\
\text { Quercus turbinella }\end{array}$ & $\begin{array}{l}d \\
f\end{array}$ \\
\hline Shrub & $\begin{array}{l}\text { Artemisia tridentata } \\
\text { Coleogyne ramosissima } \\
\text { Haplopappus linearifolius } \\
\text { Leptodactylon pungens } \\
\text { Nolina parryi } \\
\text { Opuntia erinacea } \\
\text { Purshia glandulosa } \\
\text { Salvia dormii }\end{array}$ & $\begin{array}{l}d \\
d \\
f \\
f \\
f \\
f \\
d, f \\
f\end{array}$ \\
\hline Bunchgrasses & Sitanion hystrix & $f$ \\
\hline Herbs & $\begin{array}{l}\text { Arceuthobium divaricatum } \\
\text { Artemisia ludoviciana } \\
\text { Chaenactis santolinoides } \\
\text { Erigeron aphanactis } \\
\text { Erigeron breweri } \\
\text { Eriogonum saxatile } \\
\text { Eriogonum wrightii ssp. subscaposum } \\
\text { Eriogonum umbellatum ssp. munzii } \\
\text { Eriophyllum lanatum } \\
\text { Langloisia mathewsii } \\
\text { Linanthus breviculus } \\
\text { Lotus strigosus } \\
\text { Machaeranthera canescens } \\
\text { Monardella linoides } \\
\text { Penstemon labrosus } \\
\text { Senecio bernardinus }\end{array}$ & $\begin{array}{l}f \\
f \\
f \\
f \\
f \\
f \\
f \\
f \\
f \\
f \\
f \\
f \\
f \\
f \\
f \\
f\end{array}$ \\
\hline
\end{tabular}




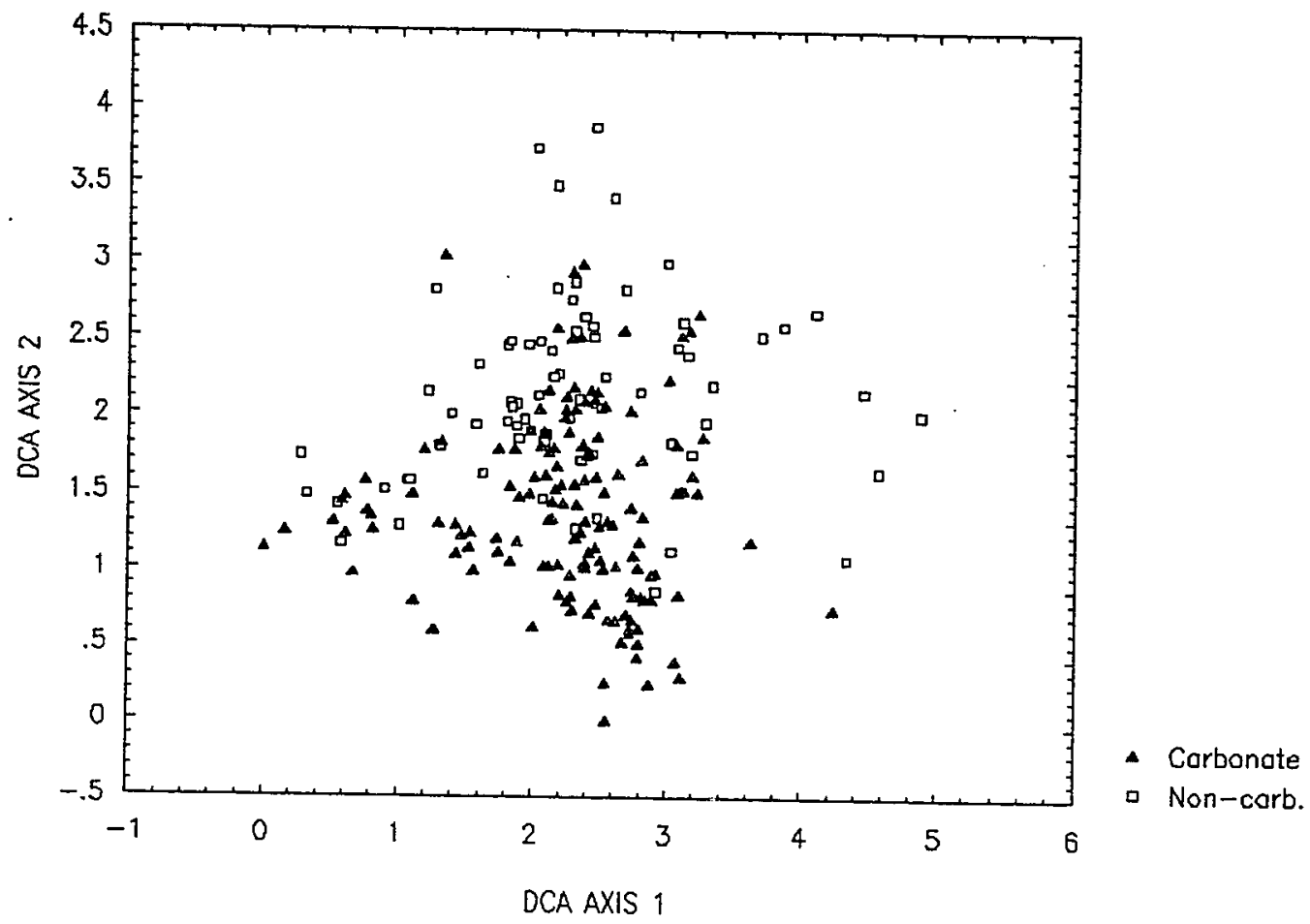

Figure 8: Ordination of randomly selected carbonate $(n=73)$ and non-carbonate plot types $(\mathrm{n}=146)$ by $\mathrm{DCA}$ axes 1 and 2 . Axis 1 is positively correlated with elevation while Axis 2 is negatively correlated with percentage calcium in the soil. 
carbonate plots were located at all elevations and of relatively low calcium content.

There was also a significant correlation between the DCA 2 Axis scores and percentage soil calcium $(\underline{E}=-0.55, \underline{p}<0.00001)$. This correlation was not as strong as that between elevation and DCA 1 Axis scores, partly because a majority of the 219 plots were of either high calcium content ( $>15 \%$ ) or low calcium content $(<0.5 \%)$, and a minority having values in between $(>0.5 \%$ and $<15 \%$ ). This significant, but relatively weak correlation indicated that factors other than soil calcium content probably influenced the vegetation. Two potential factors included mis-mapped substrates (alluvial carbonate material was not always mapped as carbonate but may have contained significant carbonate components) and the relatively large number of species (151) common to both stratifications. Dominant overstory and shrub species, common to both substrates may have also muddled the separation of the two groups along the second DCA axis through their cover values.

Comparison of sites occupied by $A$. albens and carbonate sites unoccupied by A. albens

Sites occupied by $A$. albens were within two vegetation series: the Blackbrush Scrub series dominated primarily by Coleogyne ramosissima in the shrub layer and little or no overstory layer, and the Piñon-Juniper Woodland series dominated primarily by Juniperus osteosperma and Pinus monophylla in the overstory layer and Chrysothamnus viscidiflorus ssp. stenophyllus, 
Coleogyne ramosissima, and Purshia glandulosa in the shrub layer. In general, $A$. albens habitat had an open character, with relatively low overstory and shrub cover. Herb species indicating $A$. albens habitat included Allium sp., Eriastrum saphirrinum ssp. saphirrinum, Phacelia curvipes, and Phacelia douglasii. Physically, A. albens habitat was found on sites with low slopes and gravelly soils containing a high calcium content.

In general, the physiognomy of sites occupied by $A$. albens was not dramatically different from surrounding, unoccupied carbonate sizes. However, some significant differences in species richness, environmental variables, species covers, species abundances, and ordination scores were found between the two stratifications. These visually minor, but statistically significant differences are discussed below.

A total of 167 species were recorded from the 60 randomly selected plots in which each stratification contained 30 plots. One hundred and thirty-two species were recorded in sites occupied by $A$. albens $(\underline{n}=30)$ and 122 were recorded for randomly selected unoccupied carbonate plots $(\underline{n}=30)$. Total species numbers were determined for overstory, shrub and herb species, including perennial bunchgrasses (Table 8 ). In the randomly selected plots, 84 species were common to both stratifications, 47 species were exclusive to $A$. albens centered plots ( $\underline{n}=30 ;$ Appendix 8$)$ and 38 were exclusive to plots that did not support $A$. albens $(\underline{n}=30)$. Both the mean species richness $\underline{H}=24.26$, $\underline{p}<0.00001, \underline{d f}=1)$ and mean of Shannon's diversity index $(\underline{H}=24.46, \underline{p}<$ $0.00001, \underline{d f}=1$ ) were significantly lower in unoccupied carbonate sites.

Significant differences between means of environmental variables of the two stratifications included percentage calcium in the soil $(\underline{H}=6.68, \underline{D}<0.01$, 
Table 8: Species richness by vegetation layer for sites occupied by $A$. albens and unoccupied carbonate sites using randomly selected samples of equal size.

\begin{tabular}{lcc}
\hline Species & A. albens $(n=28)$ & Unoccupied Carbonate $(n=28)$ \\
\hline Overstory & 5 & 6 \\
Shrub & 42 & 35 \\
Herb \& Bunchgrass & 85 & 81 \\
& & \\
Layers Combined & & \\
Common to both samples & 84 & 84 \\
Exclusive to one samples & 47 & 38 \\
Total Richness & 132 & 122 \\
\hline
\end{tabular}


$\underline{d f}=1)$, slope $(\underline{H}=15.24, \underline{p}<0.001, \underline{d f}=1)$, elevation $(\underline{H}=17.41, \underline{p}<0.00001, \underline{d f}=1)$, and percentage litter cover $(\underline{H}=7.71, \underline{p}<0.01, \underline{d f}=1 ;$ Table 9$)$. Significant differences between species-related variables included percentage covers of 1 overstory species, 6 shrub species, and 2 bunchgrasses, and relative abundances of 2 bunchgrasses and 25 herb species (Appendix 9). Of these, 1 overstory species, 5 shrub species, 2 bunchgrasses and 24 herbs had significantly greater mean values in sites occupied by $A$. albens compared to unoccupied carbonate sites. Species characterizing sites occupied by $A$. albens and species characterizing unoccupied carbonate sites are listed in Tables 10 and 11, respectively, and mean covers and frequencies are listed in Appendix 9.

Ordination provided an interpretable separation of $A$. albens-centered plots and carbonate plots unoccupied by $A$. albens along the first DCA Axis. The means of the DCA Axis 1 coordinates of the two groups were significantly different $(\underline{H}=33.41, \underline{p}<0.00001, \underline{d f}=1)$ suggesting a difference in vegetation between the two stratifications (Figure 9). The range of positions of the carbonate plots unoccupied by $A$. albens fully encompassed the $A$. albens-centered plots along the first DCA Axis. However, the majority of unoccupied carbonate plots had DCA Axis 1 scores higher than $A$. albens plots. This difference suggested that sites occupied by $A$. albens were found at the lower elevation range of avaiiable carbonate sites in the study area, where vegetation representing such sites was relatively less common. Both groups shared similar DCA Axis 2 means (negatively correlated with percentage calcium in the soil; Figure 9), however $A$. albens-centered plots possessed a smaller standard deviation $(\underline{\mathrm{SD}}=0.39)$ than 


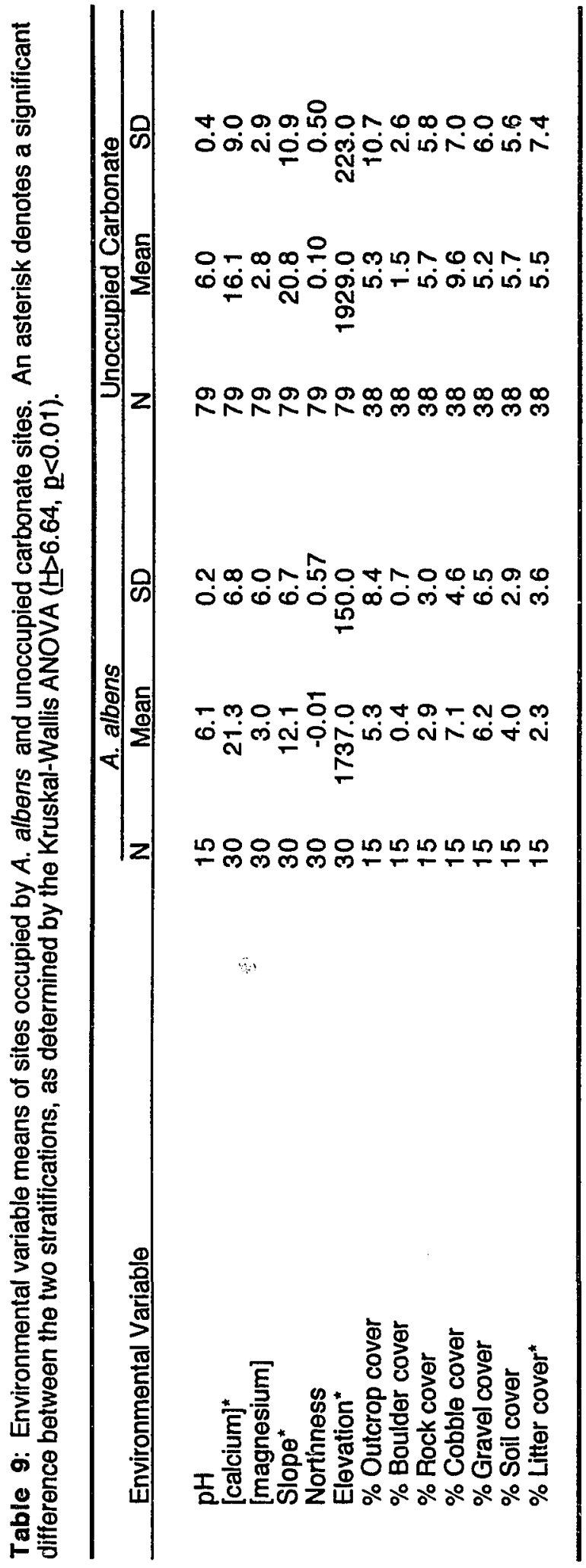


Table 10: Species characterizing sites occupied by $A$. albens, including dominants (d; overstory species: mean cover $>5 \%$, shrub and bunchgrass species: mean cover $>3 \%$ ), species with high fidelity ( $f ;>80 \%$ of species occurrences limited to plots containing $A$. albens), species with high constancy ( $c$; present in $>25 \%$ of plots containing $A$. albens), and indicator species (i; species with both high fidelity and high constancy).

\begin{tabular}{|c|c|c|}
\hline Vegetation layer & Species & Designation \\
\hline Overstory & $\begin{array}{l}\text { Juniperus osteosperma } \\
\text { Pinus monophylla }\end{array}$ & $\begin{array}{l}d \\
d\end{array}$ \\
\hline Shrub & $\begin{array}{l}\text { Chrysothamnus viscidiflorus ssp. stenophyllus } \\
\text { Coleogyne ramosissima } \\
\text { Purshia glandulosa }\end{array}$ & $\begin{array}{l}d \\
d \\
d\end{array}$ \\
\hline Bunchgrass & Sporobolus cryptandrus & $f$ \\
\hline Herbs & $\begin{array}{l}\text { Allium sp. } \\
\text { Cryptantha angustifolia } \\
\text { Eriastrum densiflorum } \\
\text { Eriastrum saphirrinum ssp. saphirinum } \\
\text { Eriogonum inflatum } \\
\text { Eriogonum maculatum } \\
\text { Eriogonum nidularium } \\
\text { Eriophyllum sp. } \\
\text { Nemacladus longiflorus } \\
\text { Parishella californica } \\
\text { Phacelia curvipes } \\
\text { Phacelia douglasii }\end{array}$ & $\begin{array}{l}i \\
f \\
f \\
i \\
f \\
f \\
f \\
f \\
f \\
f \\
i \\
i\end{array}$ \\
\hline
\end{tabular}


Table 11: Species characterizing carbonate sites unoccupied by $A$. albens, including dominants (d; overstory species: mean cover $>5 \%$, shrub and bunchgrass species: mean cover $>3 \%$ ), species with high fidelity ( $f ;>80 \%$ of species occurrences limited to carbonate plots not containing $A$. albens), species with high constancy (c; present in $>25 \%$ of carbonate plots not containing $A$. albens), and indicator species (i; species with both high fidelity and high constancy).

\begin{tabular}{lll}
\hline Vegetation laver & Species & Designation \\
\hline Overstory & $\begin{array}{l}\text { Juniperus osteosperma } \\
\text { Pinus monophylla }\end{array}$ & $\mathbf{d}$ \\
Shrub & Arctostaphylos glauca & $\mathbf{d}$ \\
& $\begin{array}{l}\text { Cercocarpus ledifolius } \\
\text { Chrysothamnus viscidiflorus ssp. stenophyllus }\end{array}$ & $\mathbf{d}$ \\
& Sitanion hystrix & $\mathbf{d}$ \\
Bunchgrass & Caulanthus major & $\mathbf{i}$ \\
Herbs & Phlox austromontanum & $\mathbf{i}$ \\
& & $\mathbf{i}$ \\
\hline
\end{tabular}




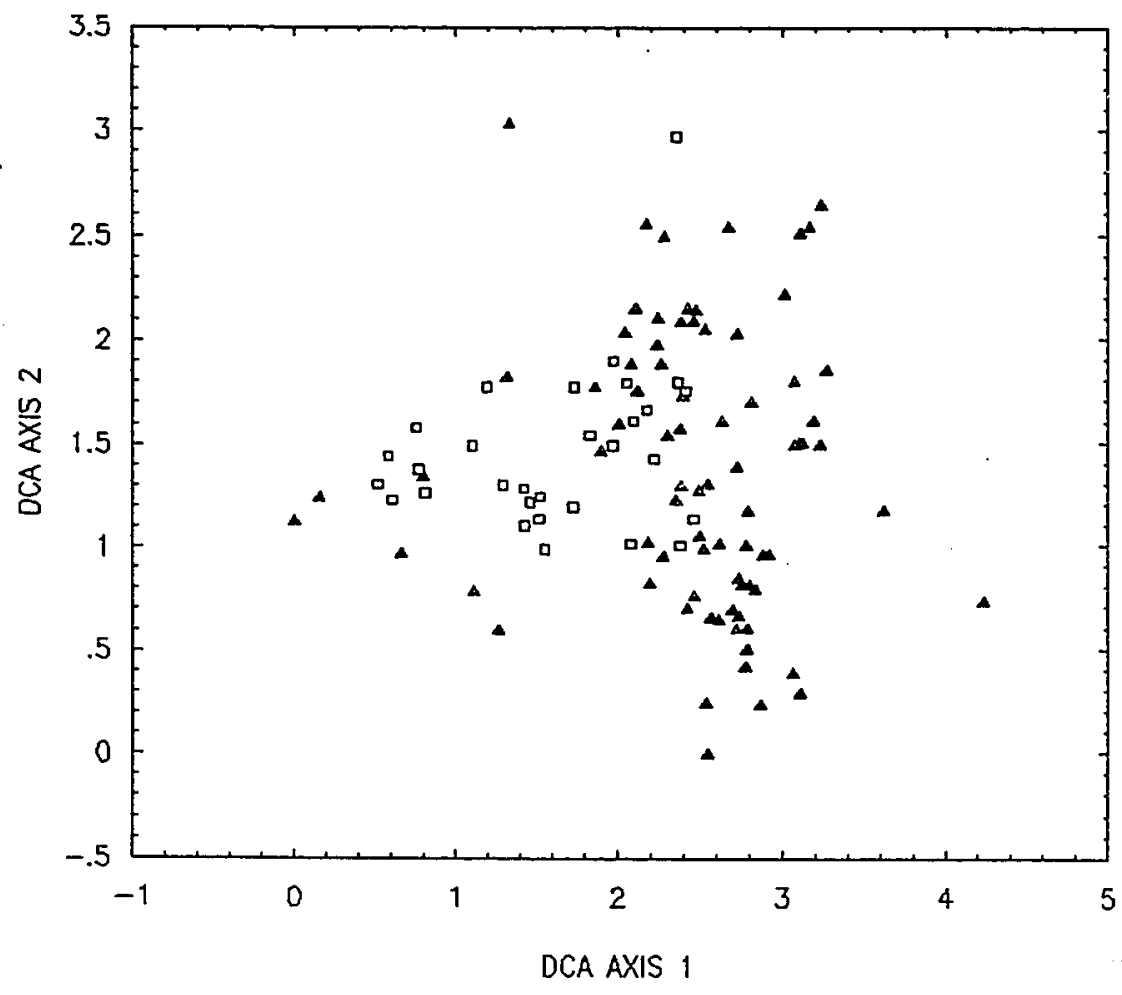

- Astragalus albens

- Unoccupied Corborsate

Figure 9: Ordination of $A$. albens-centered plots $(n=30)$ and carbonate plots unoccupied by $A$. albens $(n=79)$, by DCA axes 1 and 2 . Axis 1 is positively correlated with elevation while Axis 2 is negatively correlated with percentage calcium in the soil. 
unoccupied carbonate plots $(\underline{S D}=0.68)$. Thus, sites occupied by $A$. albens appeared restricted to only a portion of the available carbonate sites.

Comparison of sites occupied by $E$. o. ssp.vineum and carbonate sites unoccupied by $E$. 0 . ssp.vineum

Sites occupied by E. 0 . ssp. vineum were within the Piñon-Juniper Woodiand series dominated primarily by Juniperus osteosperma and Pinus monophylla in the overstory layer and Cercocarpus ledifolius, Chrysothamnus viscidiflorus ssp.stenophyllus, and Ephedra viridis in the shrub layer. Herb species indicating E. o. ssp.vineum habitat included Arabis shockleyi, Cryptantha confertiflora, and Phacelia douglasii. Physically, E. o. ssp. vineum habitat was found on steep, often north-facing sites, with rocky, friable soils containing a high calcium content.

Like sites occupied by $A$. albens, the general physiognomy of sites occupied by $E$. 0 . ssp.vineum was not dramatically different from surrounding, unoccupied carbonate sites. However, some significant differences in species richness, environmental variables, species covers, species abundances, and ordination scores were found between the two stratifications. These significant differences are discussed below.

A total of 151 species were recorded from the 56 selected plots in which each stratification contained 28 plots. One hundred and eight species were recorded for plots occupied by E. o. ssp.vineum $(n=28)$ and 123 were recorded for randomly selected unoccupied carbonate plots not occupied by $E$. 0 . 
ssp. vineum ( $\underline{n}=28 ;$ Table 12). Eighty-five species were common to both stratifications in this comparison, 25 species were exclusive to sites occupied by E. o. ssp.vineum ( $\underline{n}=28$; Appendix 10) and 39 were exclusive to carbonate sites which did not support E. 0 . ssp. vineum $(\underline{n}=28)$. The mean species diversity differed significantly between the two stratifications $(\underline{H}=7.09, \underline{p}<0.01, \underline{\mathrm{df}}=1)$.

Significant differences between means of environmental variables of the two stratifications included percentage calcium in soil $\underline{\underline{H}}=18.18, \underline{\mathrm{p}}<0.00001$, $\underline{d f}=1)$ and percentage outcrop cover $(\underline{H}=7.77, \underline{p}<0.01, \underline{d i}=1$; Table 13). Significant differences between means of species-related variables included total canopy heigint ( $\underline{\mathrm{H}}=10.60, \underline{\mathrm{p}}<0.001, \underline{\mathrm{df}}=1$ ), height of Juniperus osteosperma $(\underline{H}=11.27, \underline{p}<0.001, \underline{d f}=1)$, percentage cover of 2 overstory species, 3 shrub layer species, and 2 perennial bunchgrass species, and the relative abundance of 2 perennial bunchgrasses and 3 herb species (Appendix 11). Of these, 1 overstory species, 2 shrub species, 2 bunchgrasses and 4 herbs had significantly greater mean values in sites occupied by $E$. 0 . ssp. vineum compared to unoccupied carbonate sites by E. o. ssp.vineum. Species characterizing sites occupied by $E$. 0 . ssp. vineum and species characterizing carbonate sites unoccupied are listed in Tables 14 and 15, respectively. Mean covers and frequencies of species characterizing sites occupied by $E$. $O$. ssp.vineum are listed in Appendix 11.

Eriogonum ovalifolium ssp. vineum and unoccupied carbonate plots had significantly different means along the second DCA Axis $(\underline{H}=8.04, \underline{p}<0.01$, $\underline{\mathrm{df}}=1$; Figure 10). DCA scores of $E$. 0 . ssp. vineum-centered plots fell within the range of both DCA Axis 1 and 2 scores of carbonate plots unoccupied by $E$. 0 . ssp.vineum. In addition, standard deviations of E. o. ssp. vineum-cemtered plots 
Table 12: Total species richness by vegetation layer for sites occupied by $E$. 0 . ssp. vineum and unoccupied carbonate sites using randomly selected samples of equal size.

\begin{tabular}{|c|c|c|}
\hline Species & E. 0. ssp. vineum $(n=28)$ & Unoccupied Carbonate $(n=28)$ \\
\hline $\begin{array}{l}\text { Overstory } \\
\text { Shrub } \\
\text { Herbs \& Bunchgrasses }\end{array}$ & $\begin{array}{r}4 \\
34 \\
70\end{array}$ & $\begin{array}{r}6 \\
36 \\
81\end{array}$ \\
\hline $\begin{array}{l}\text { Layers Combined } \\
\text { Common to both samples } \\
\text { Exclusive to one sample } \\
\text { Total Richness }\end{array}$ & $\begin{array}{r}85 \\
26 \\
108\end{array}$ & $\begin{array}{r}85 \\
39 \\
123\end{array}$ \\
\hline
\end{tabular}




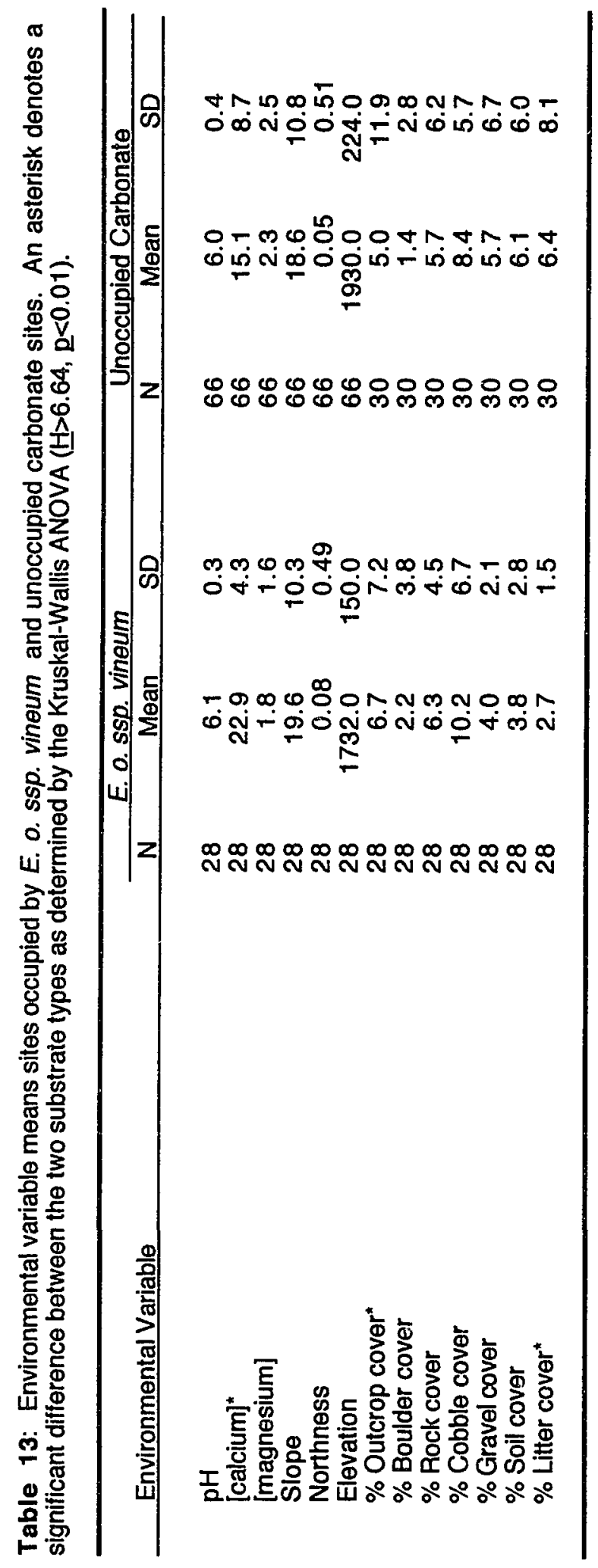


Table 14: Species characterizing sites occupied by $E$. o. ssp.vineum including dominants (d; overstory species: mean cover $>5 \%$, shrub and bunchgrass species: mean cover $>3 \%$ ), species with high fidelity ( $f ;>80 \%$ of species occurrences limited to plots containing $E$. 0 . ssp.vineum), species with high constancy (c; present in $>25 \%$ of plots containing $E$. o. ssp.vineum), and indicator species ( $i$; species with both high fidelity and high constancy).

\begin{tabular}{|c|c|c|}
\hline Vegetation layer & Species & Designation \\
\hline Overstory & $\begin{array}{l}\text { Juniperus osteosperma } \\
\text { Pinus monophylla }\end{array}$ & $\begin{array}{l}d \\
d\end{array}$ \\
\hline Shrub & $\begin{array}{l}\text { Cercocarpus ledifolius } \\
\text { Chrysothamnus viscidiflorus ssp. stenophyllus } \\
\text { Ephedra viridis }\end{array}$ & $\begin{array}{l}d \\
d \\
d\end{array}$ \\
\hline Herbs & $\begin{array}{l}\text { Arabis shockleyi } \\
\text { Cryptantha confertiflora } \\
\text { Phacelia douglasii }\end{array}$ & $\begin{array}{l}c(f=50 \%) \\
c(f=75 \%) \\
i\end{array}$ \\
\hline
\end{tabular}

Table 15: Species characterizing sites unoccupied by $E$. o. ssp.vineum including dominants (d; overstory species: mean cover $>5 \%$, shrub and bunchgrass species: mean cover $>3 \%$ ), species with high fidelity ( $f ;>80 \%$ of species occurrences limited to carbonate plots not containing $E$. $o$. ssp. vineum), species with high constancy (c; present in $>25 \%$ of carbonate plots not containing E. o. ssp.vineum), and indicator species (i; species with both high fidelity and high constancy).

\begin{tabular}{lll}
\hline Vegetation layer & Species & Designation \\
\hline Overstory & Juniperus osteosperma & $\mathrm{d}$ \\
& $\begin{array}{l}\text { Pinus monophylla } \\
\text { Quercus chrysolepis }\end{array}$ & $\mathrm{d}$ \\
Shrub & Amelanchier utahensis & $\mathrm{f}$ \\
& Arctostaphylos glauca & $\mathrm{f}$ \\
& Cercocarpus ledifolius & $\mathrm{d}$ \\
& Chrysothamnus viscidiflorus ssp. stenophyllus & $\mathrm{d}$ \\
Bunchgrass & Sitanion hystrix & $\mathrm{d}$ \\
& & $\mathrm{i}$ \\
\hline
\end{tabular}




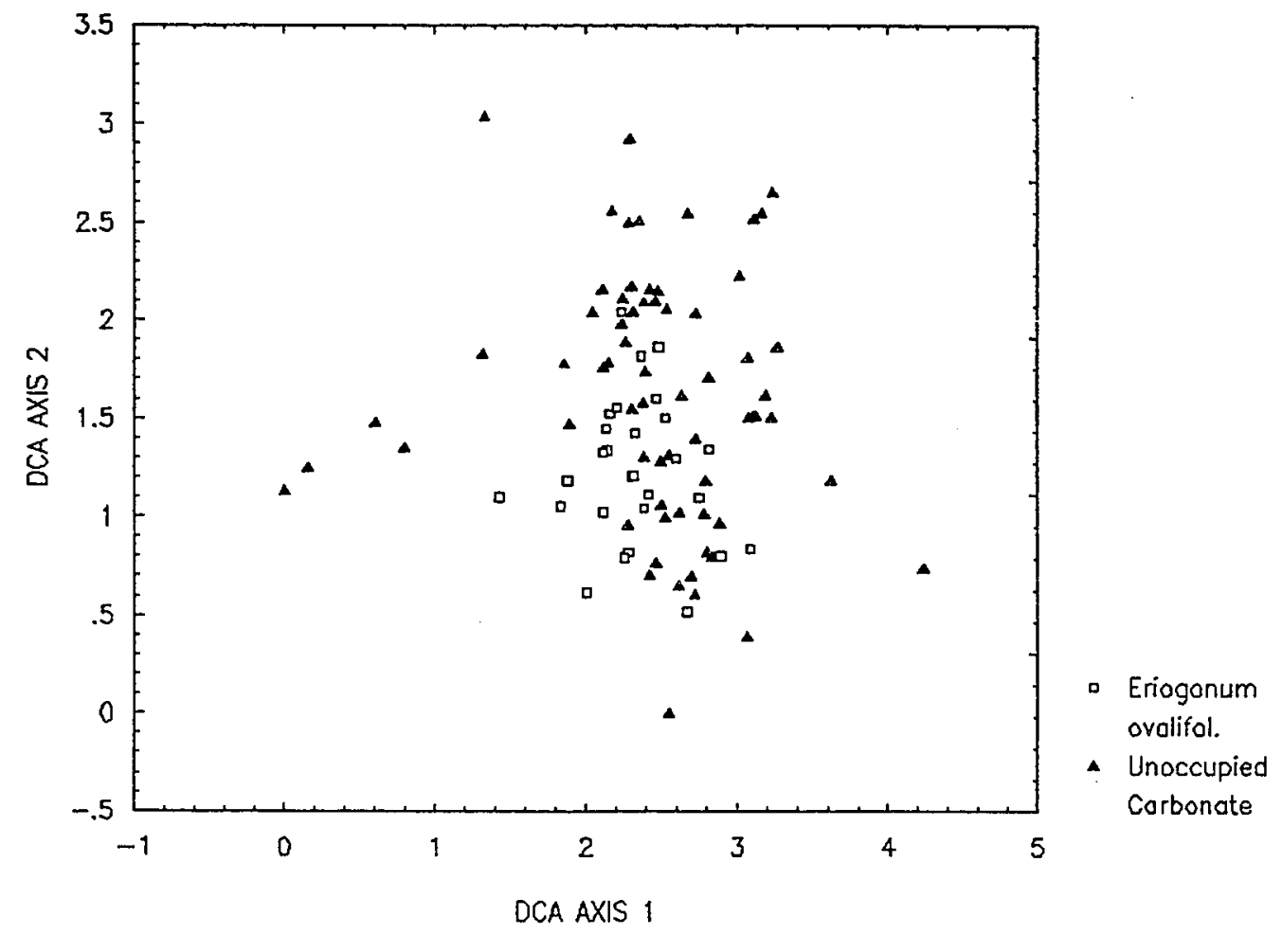

Figure 10: Ordination of E. o. ssp. vineum-centered plots $(\underline{n}=28)$ and carbonate sites unoccupied by $E$. 0 . ssp. vineum $(n=66)$, by DCA axes 1 and 2 . Axis 1 is positively correlated with elevation while Axis 2 is negatively correlated with percentage calcium in the soil. 
were restricted to only a portion of the available carbonate sites in the study area.

\section{Vegetation Type Classification}

The primary TWINSPAN division separated the 219 plots into a Piñon Woodland Series and a Blackbrush Scrub Series (Figure 11). At level two TWINSPAN separated out Piñon Pine-Utah Juniper groups from Piñon Pine communities, and a Blackbrush Scrub-Piñon Pine transitional group from true Blackbrush Scrub. However, differentiation among groups distinguished by these iwo upper levels of the classification were only moderately strong, as indicated by their eigenvalues (Level 1 division $=0.284$; mean of Level 2 divisions $=0.287$ ).

The Blackbrush Scrub group from Level 2 was retained while the other three groups from TWINSPAN were divided further at the next three levels (3-5). At Level 3 the classification distinguished a Yellow Pine Forest-Piñon Pine group from the Piñon Pine groups. It also separated Piñon-Juniper Woodlands and a Blackbrush Scrub-Piñon-Juniper Woodland transitional group containing a strong Yucca brevifolia component from those in which this species was lacking. Groupings at this level were relatively distinct, with eigenvalues ranging from 0.207 to 0.427 . From Level 3 the Yellow Pine Forest-Piñon Pine transition group and the Blackbrush Scrub-Piñon-Juniper transitional group with the strong Yucca brevifolia component were retained. Levels 4 and 5 of the classification resulted in further subdivisions of the remaining four groups 


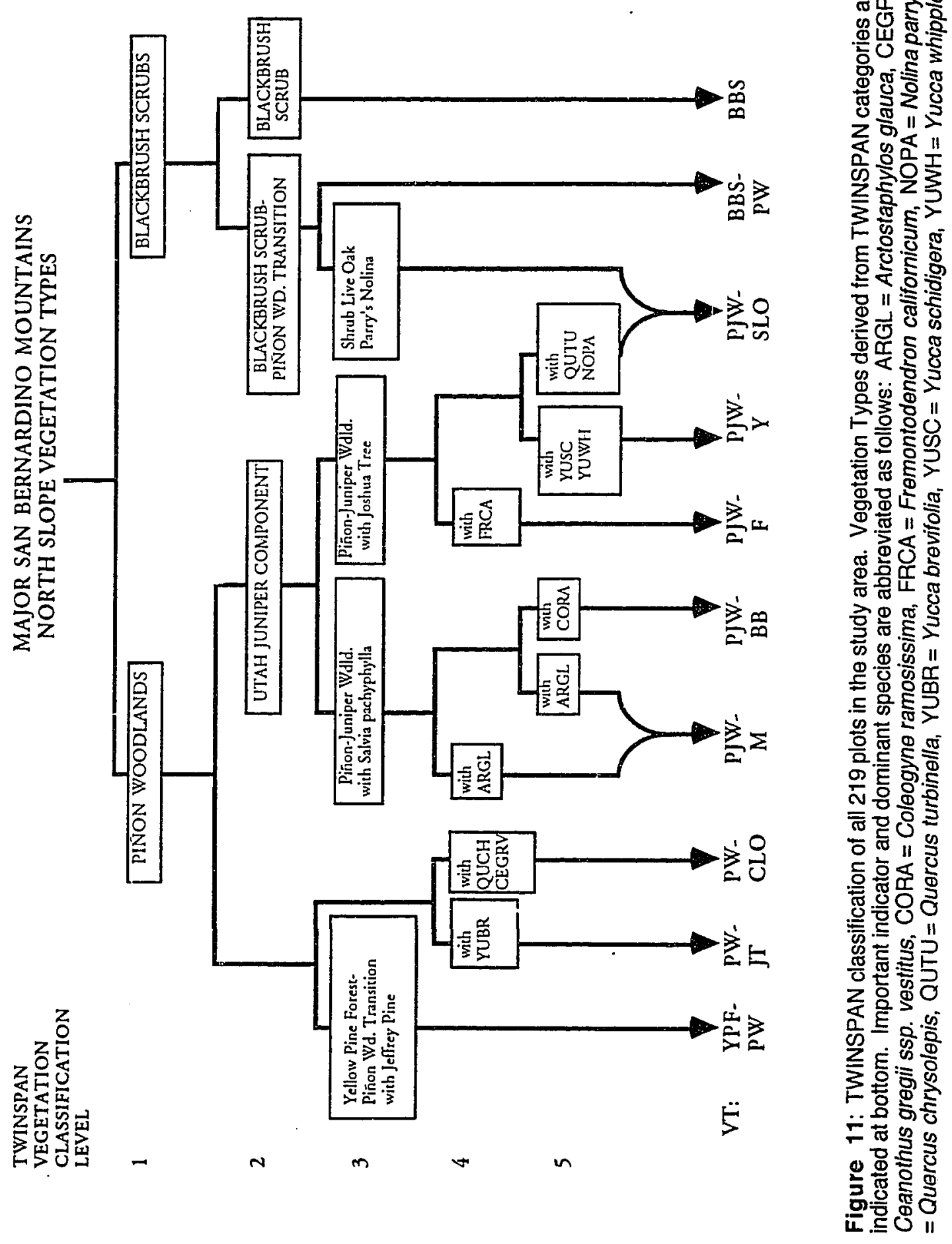


into sixteen groups. Using combinations of these groups, seven more vegetation types (VTs) were formed.

The classification procedure ultimately identified 10 major VTs (Figure 11). All ten VTs were found within four, previously documented vegetation series, including Blackbrush Scrub, Piñon-Juniper Woodlands, Piñon Woodlands (Barbour and Major 1990; Holland 1986; Thorne 1982). The first series, Blackbrush Scrub, was represented by two vegetation types, Blackbrush Scrub (BBS) and Blackbrush Scrub-Piñon Woodland transition (BBS-PW). These were closely analogous to previously described Blackbrush Scrubs for California (Barbour and Major 1990; Holland 1986; Thorne 1982), but containing the shrub Artemisia tridentata instead of Artemisia spinescens, the bunchgrass Sitanion hystrix instead of Sitanion longifolium, and not containing the shrubs Agave utahensis, Yucca baccata and Thamnosma montarna, nor the bunchgrass Hilaria rigida.

The second series, Piñon-Juniper Woodlands, was represented by five vegetation types, Piñon-Juniper Woodland with Shrub Live Oak (PJW-SLO), Piñon-Juniper Woodland with Blackbrush Scrub (PJW-BB), Piñon-Juniper Woodland with Manzanita (PJW-M), Piñon-Juniper Woodland with Flannelbush (PJW-F), and Piñon-Juniper Woodland with Yucca spp. (PJW-Y), containing both One-Leaf Piñon Pine (Pinus monophylla) and Utah Juniper (Juniperus osteosperma). These types most closely resemble the species composition of Holland's Great Basin Piñon-Juniper Woodland (1986).

The third series, Piñon Woodlands, was represented by two vegetation types, Piñon Woodland with Joshua Tree (PW-JT) and Piñon Woodland with Canyon Live Oak (PW-CLO). The Piñon Woodlands compositional group 
contained very few Juniper occurrences, representing further refinements of Holland's Mojavean Piñon Woodland (1986).

The fourth basic compositional group, the Yellow Pine Forest, was represented by one vegetation type, Yellow Pine Forest-Piñon Woodland transition (YPF-PW). This vegetation type most closely resembled previously described Mountain Juniper Woodlands (Barbour and Major 1990; Thorne 1982) and Jeffrey Pine Forest (Holland 1986), but differed from Holland's Jeffrey Pine Forest by containing a significant Pinus monophylla component.

Vegetation series and types were loosely arranged along an elevation gradient (Figure 12). The 10 major VTs found in the first TVVINSPAN analysis using only vegetational cover data were validated by a second TWINSPAN analysis using plant species presence/absence data. Sixteen plots were reassigned to groups other than those indicated by TWINSPAN primarily on the basis of dominant, indicator and characteristic species. No TWINSPAN groups with fewer than 5 plots were used as VTs for the purposes of this study.

The 10 recognized vegetation types were categorized as either carbonate or non-carbonate, depending on the percentage of plots of each substrate type (Table 16). No VT had a substrate constancy of less than $63 \%$, allowing all VTs to fall into one of the two substrate affiliation categories. However, only one VT was found exclusively on one substrate type. 


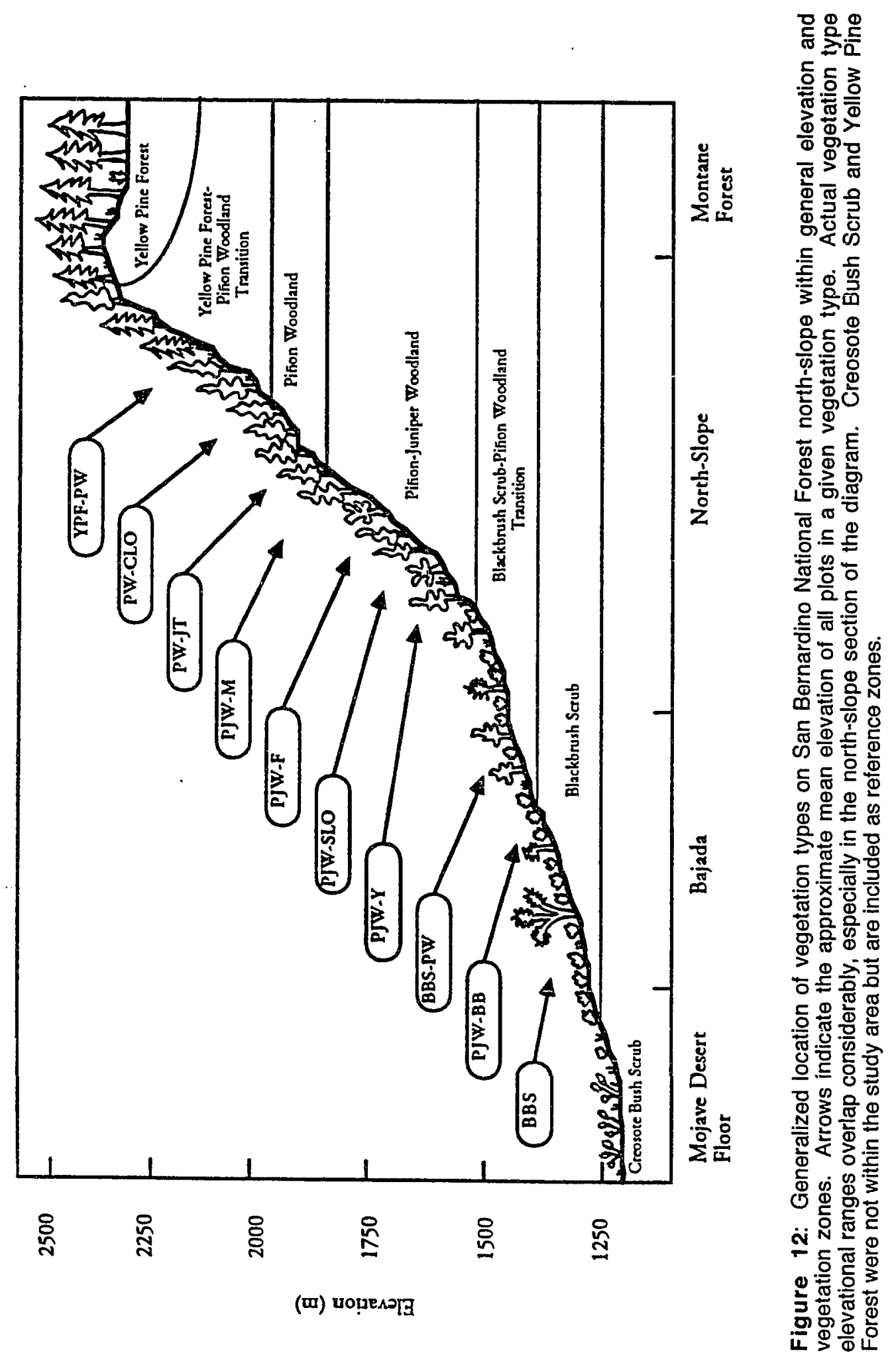


Table 16: Vegetation type distribution among carbonate and non-carbonate substrates. There were 146 plots on carbonate substrates and 73 on non-carbonate substrates.

\begin{tabular}{lcccc}
\hline VT & N & Substrate Affiliation & $\begin{array}{c}\text { Percentage } \\
\text { Carbonate Plots }\end{array}$ & $\begin{array}{c}\text { Percentage } \\
\text { Non-Carbonate Plots }\end{array}$ \\
\hline BBS & 20 & Carbonate & 67 & 33 \\
PJW-BB & 15 & Carbonate & 100 & 0 \\
BBS-PW & 8 & Non-Carbonate & 25 & 75 \\
PJW-Y & 15 & Carbonate & 63 & 37 \\
PJW-SLO & 15 & Non-Carbonate & 7 & 93 \\
PJW-F & 50 & Carbonate & 94 & 6 \\
PJW-M & 47 & Carbonate & 98 & 65 \\
PW-ST & 14 & Non-Carbonate & 35 & 69 \\
PW-CLO & 13 & Non-Carbonate & 31 & 67 \\
YPF-PW & 15 & Non-Carbonate & 33 & \\
\hline
\end{tabular}




\section{Vegetation Types Associated with Astragalus albens}

Distribution of $A$. albens was primarily within BBS, PJW-BB, PJW-F (Figure 13). Forty-two percent of $A$. albens occurrences were found within the two Blackbrush-related communities (BBS and PJW-BB) characterized by relatively gentle slopes, high percentage cover of cobble, gravel and soil, and low overstory cover. Combined, these VTs were encountered less than $20 \%$ out of all plots sampled $(\underline{n}=219$ ), but were not particularly relatively rare nor common in the study area. It appeared that $A$. albens occurrences were disproportionately represented in a relatively limited number of VTs. Another thirty-eight percent of $A$. albens occurrences were within PJW-F also characterized by relatively gentle siopes, and $11 \%$ of $A$. albens occurrences were within other carbonate affiliated VTs. Nine percent of $A$. albens occurrences were found within carbonate plots which happened to be categorized into a non-carbonate affiliated $\mathrm{VT}$.

Vegetation Types Associated with Eriogonum ovalifolium ssp. vineum

Eriogonum ovalifolium ssp. vineum was found primarily in three of five carbonate affiliated VTs, PJW-F, PJW-M, and PJW-BB (Figure 14). Seventyeight percent of occurrences were found within two Piñon-Juniper Woodland communities (PJW-F and PJW-M) characterized by relatively moderate to steep slopes, moderate geologic cover, and moderate overstory and shrub covers. These two VTs were the most common vegetation types occurring in the study 


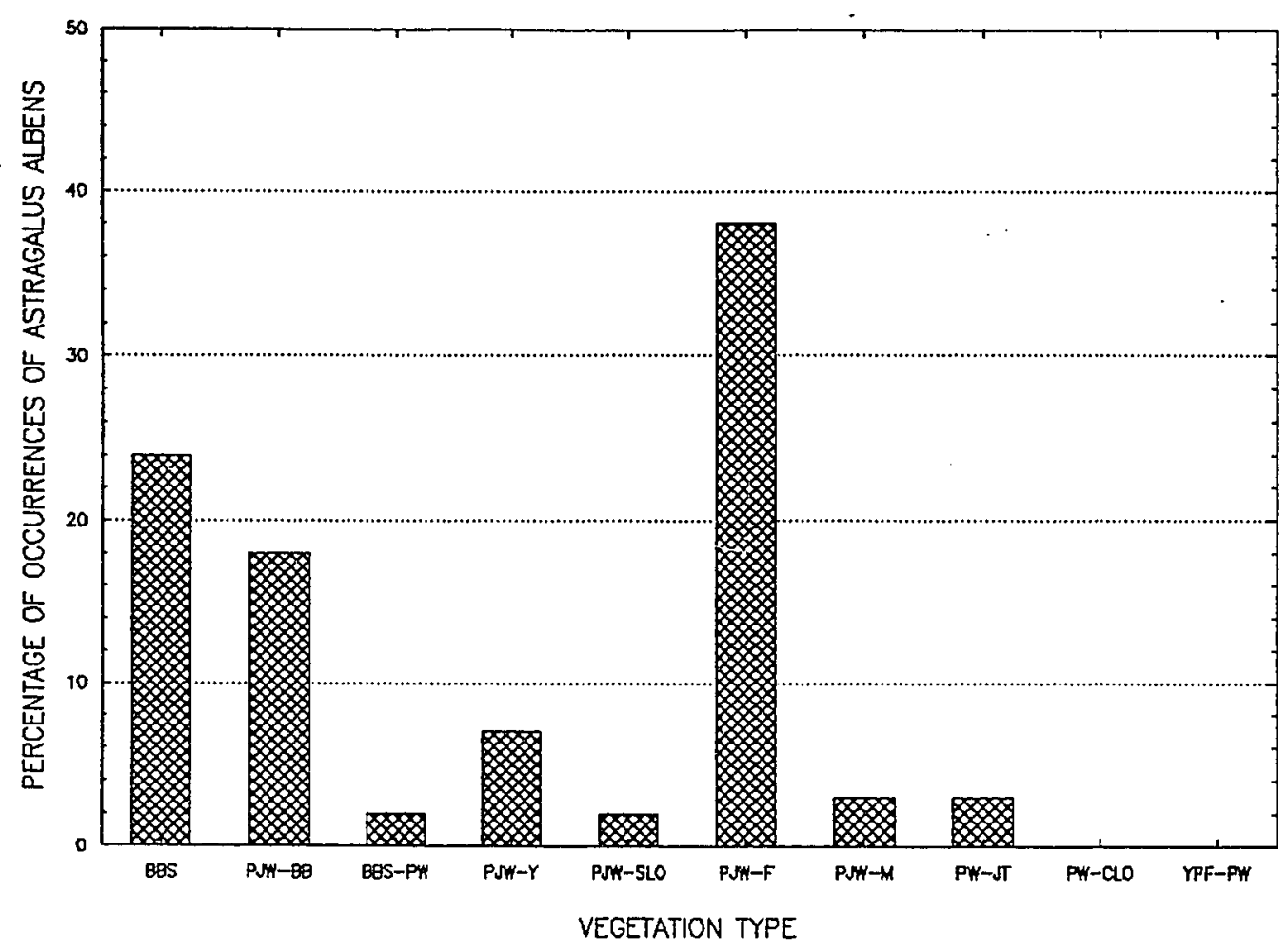

Figure 13: Percentage of $A$. albens plots $(\underline{n}=30$ ) occurring in each of the 10 recognized vegetation types. 


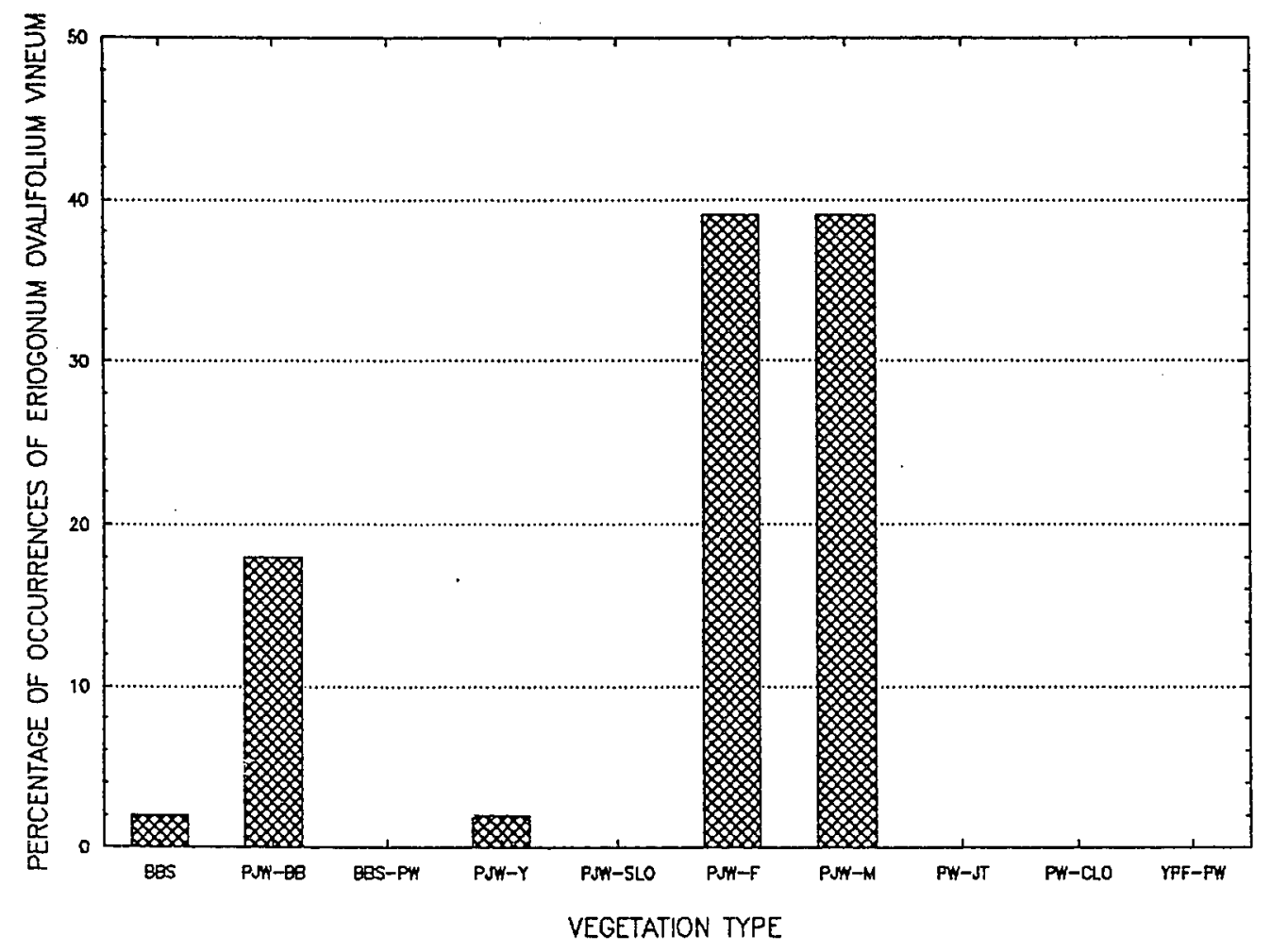

Figure 14: Percentage of E. o. ssp.vineum plots $(\underline{n}=28)$ occurring in each of the 10 recognized vegetation types. 
area. Another $18 \%$ of occurrences were within PJW-BB characterized by relatively steep slopes and the presence of Coleogyne ramosissima.

Astragalus albens or E. o. ssp. vineum occurred in BBS, PJW-BB, PJWM, PJW-F but only co-occurred within PJW-BB and PJW-F VTs (Figures 13 and 14). PJW-BB was a relatively rare vegetation type, encountered in only $6 \%$ of all plots, while PJW-F was a relatively common vegetation type, encountered in $23 \%$ of all plots in the study area. In BBS $A$. albens occurred largely without $E$. 0. ssp.vineum (only 1 occurrence of $E$. 0 . ssp. vineum occurrence) while in PJW-M E. o. ssp.vineum occurred largely without $A$. albens (only 2 occurrences of $A$. albens). The habitats represented by these two VTs were markedly different in two ways: BBS had the lowest mean elevation and slope degrees, while PJW-F had the highest mean elevation and slope. In carbonate plots occupied by the target species it appeared that the elevation and slope ranges of $A$. albens extended below that of E. O. ssp. vineum. Conversely, the elevation and slope ranges of $E$. o. ssp. vineum extended above that of $A$. albens. Within these range differences, vegetational differences in sites were also observed, including greater percentage overstory cover in PJW-M and greater percentage shrub cover in BBS.

\section{Description of VTs Associated with the Target Species}

The 4 VTs associated with $A$. albens and $E$. o. ssp. vineum were described by dominant and indicator species, means of the thirteen environmental variables used in stratification comparisons, and means of 
vegetational variables including total species richness, mean species richness, Shannon's diversity index, total overstory and shrub covers, and total canopy height (Tables 17-22). Comprehensive species lists were also compiled for each VT associated with the target species (Appendices 12-15). Quantitative information was used to qualitatively describe these $4 \mathrm{VTS}$ associated with the target species as follows:

Blackbrush Scrub ( $n=21$ ): BBS had little or no overstory and was dominated by the shrubs Coleogyne ramosissima and Gutierrezia microcephala. Indicator shrub species included Ephedra nevadensis, and Salvia mojavensis. The herbs Eriogonum inflatum, Mirabilis bigelovii, and Cryptantha nevadensis were indicator species and abundance dominants in BBS. This community contained the highest values of total species richness, mean species richness and diversity of all VTs. It was also characterized by relatively xeric sites, as measured by the northness index, found on low to moderately sloping foothills and bajadas. BBS had an open character due to low cover of larger geologic categories (rock, boulder and outcrop) combined with low overstory cover and height and high shrub cover. BBS was the third most common of all VTs in the study area, encountered in $10 \%$ of all plots.

Piñon-Juniper Woodland with Blackbrush ( $n=15)$ : PJW-BB had the second lowest mean elevation and was dominated by Juniperus osteosperma and Pinus monophylla in the overstory layer and by Coleogyne ramosissima and Cercocarpus ledifolius in the shrub layer. Aristida fendleriana dominated the herb layer in relative abundance. Indicator species included the shrub 


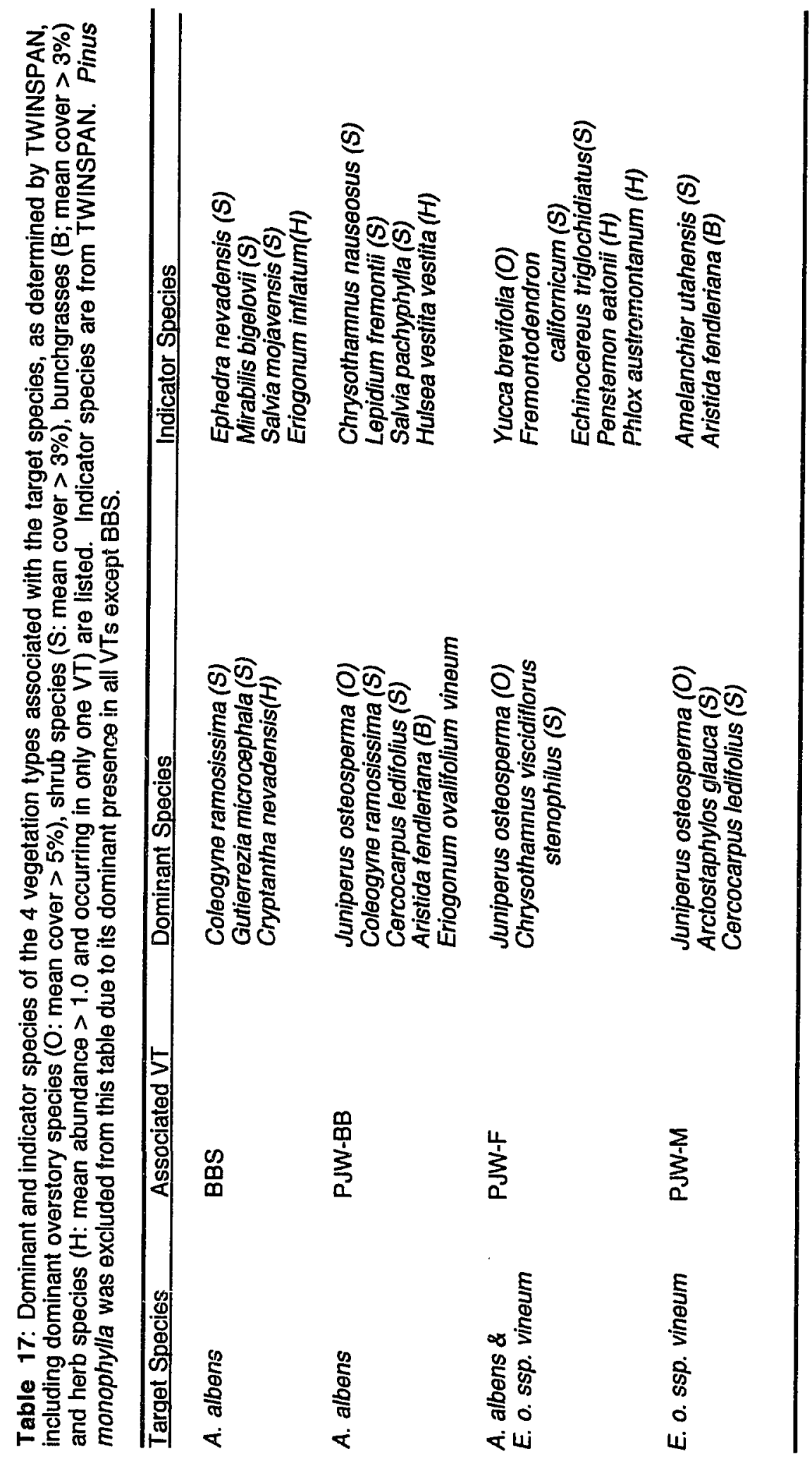


Table 18: Physical characteristics of vegetation types associated with the target species including elevation (meters), northness (negative numbers indicate more south-facing sites while positive numbers indicate more north-facing sites), and slope (degrees).

\begin{tabular}{|c|c|c|c|c|c|c|c|}
\hline \multirow[b]{2}{*}{ VT } & \multirow[b]{2}{*}{$\mathrm{N}$} & \multicolumn{2}{|c|}{ Elevation $(\mathrm{m})$} & \multicolumn{2}{|c|}{ Northness } & \multicolumn{2}{|c|}{ Slope (degrees) } \\
\hline & & Mean & $\mathrm{SD}$ & Mean & $\mathrm{SD}$ & Mean & SD \\
\hline $\begin{array}{l}\text { BBS } \\
\text { PJW-BB } \\
\text { PJW-F } \\
\text { PJW-M }\end{array}$ & $\begin{array}{l}20 \\
15 \\
50 \\
47\end{array}$ & $\begin{array}{l}1569 \\
1661 \\
1888 \\
1955\end{array}$ & $\begin{array}{l}106 \\
142 \\
154 \\
219\end{array}$ & $\begin{array}{r}-.090 \\
.381 \\
-.022 \\
.042\end{array}$ & $\begin{array}{l}.48 \\
.46 \\
.54 \\
.47\end{array}$ & $\begin{array}{l}14.0 \\
19.7 \\
16.1 \\
23.1\end{array}$ & $\begin{array}{r}9.0 \\
10.1 \\
9.2 \\
11.1\end{array}$ \\
\hline
\end{tabular}



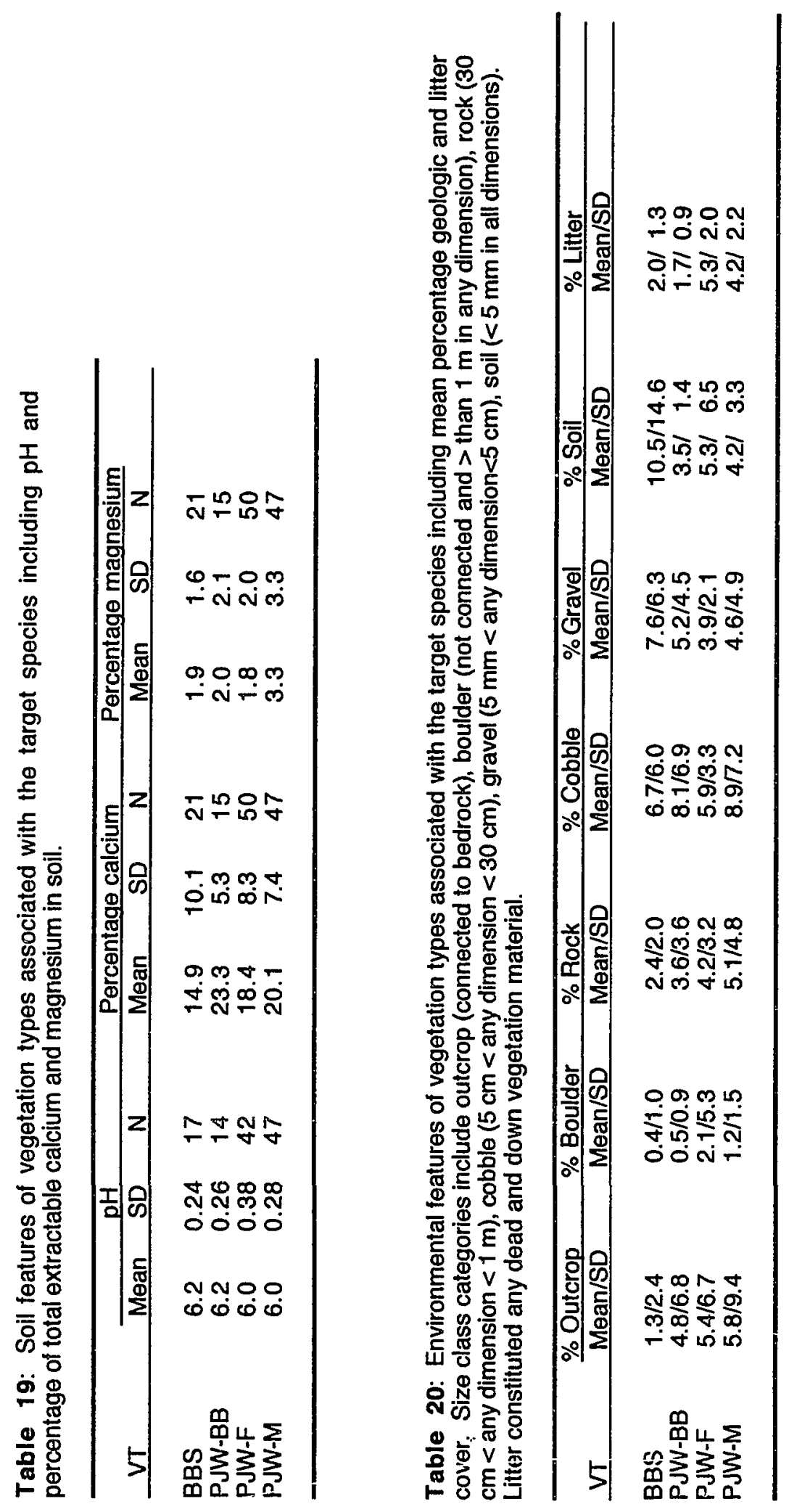
Table 21: Mean species richness, total species richness and Shannon's diversity index by vegetation types associated with the target species. Significant differences between specific VTs were not determined.

\begin{tabular}{lcccc}
\hline VT & N & Mean Richness & Total Richness & Diversity \\
\hline BBS & 20 & 30.2 & 143 & 1.24 \\
PJW-BB & 15 & 27.0 & 103 & 1.20 \\
PJW-F & 50 & 22.5 & 116 & 1.08 \\
PJW-M & 47 & 18.9 & 114 & 1.03 \\
\hline
\end{tabular}

Table 22: Structural features of vegetation types associated with the target species including mean $\mathrm{DBH}(\mathrm{cm})$, mean canopy height $(\mathrm{m})$, total shrub cover, and total overstory cover.

\begin{tabular}{|c|c|c|c|c|c|c|c|c|c|}
\hline \multirow[b]{2}{*}{$\mathrm{VT}$} & \multicolumn{3}{|c|}{ Overstory Cover $(\%)$} & \multicolumn{3}{|c|}{ Shrub Cover (\%) } & \multicolumn{3}{|c|}{ Canopy Height (m) } \\
\hline & Miean & SD & $N$ & Mean & SD & $N$ & Mean & SD & $\mathbf{N}$ \\
\hline $\begin{array}{l}\text { BBS } \\
\text { PJW-BB } \\
\text { PJW-F } \\
\text { PJW-M }\end{array}$ & $\begin{array}{r}7.6 \\
16.5 \\
33.5 \\
20.3\end{array}$ & $\begin{array}{r}7.4 \\
11.3 \\
15.9 \\
13.4\end{array}$ & $\begin{array}{l}13 \\
11 \\
25 \\
28\end{array}$ & $\begin{array}{l}56.6 \\
41.1 \\
31.6 \\
38.7\end{array}$ & $\begin{array}{l}21.1 \\
12.2 \\
15.3 \\
16.2\end{array}$ & $\begin{array}{l}13 \\
11 \\
25 \\
28\end{array}$ & $\begin{array}{l}3.2 \\
2.6 \\
3.9 \\
3.8\end{array}$ & $\begin{array}{l}1.5 \\
0.8 \\
1.3 \\
2.3\end{array}$ & $\begin{array}{l}20 \\
15 \\
50 \\
47\end{array}$ \\
\hline
\end{tabular}


species Chrysothamnus nauseosus, Lepidium fremontii, and Salvia pachyphylla and the herb species Hulsea vestita ssp. vestita and E. o. ssp. vineum. Forty percent of the occurrences of $E$. 0 . ssp. vineum were in this VT. PJW-BB differed markedly from BBS, occurring on steeper, north-facing slopes, generally indicative of slightly more mesic sites. Due to the dominant presence of Juniperus osteosperma, the PJW-BB type was separated from the other Blackbrush Scrub-related types and classified within the Piñon-Juniper Woodlands. PJW-BB also contained more small sized geologic cover (cobble, gravel, soil) than large sized (outcrop, boulder, rock). PJW-BB was a relatively rare VT in the study area, encountered in only $7 \%$ of all plots.

Piñon-Juniper Woodland with Flannelbush ( $n=50)$ : PJW-F had the fifth highest mean elevation and was dominated by Juniperus osteosperma and Pinus monophylla in the overstory layer, and by Chrysothamnus viscidiflorus ssp. stenophyllus in the shrub layer. Indicator species for this VT included Yucca brevifolia in the overstory layer, Fremontodendron californicum and Echinocereus triglochidiatus in the shrub layer, and Penstemon eatonii and Phlox austromontanum in the herb layer. This VT was found predominantly on carbonate substrates. PJW-F was a common VT in the study area, encountered in $23 \%$ of all plots.

Piñon-Juniper Woodland with Manzanita ( $n=47)$ : PJW-M, the highsst Piñon-Juniper Woodland community, had the fourth highest mean elevakiton and was dominated by Juniperus osteosperma and Pinus monophylla in the overstory layer and by Arctostaphylos glauca and Cercocarpus ledifolius in the 
shrub layer. Indicator species for this VT included Amelanchier utahensis in the shrub layer and the bunchgrass Aristida fendleriana. The occurrence of manzanita (Arctostaphylos glauca) largely restricted to this VT. PJW-M was distinguished from the other Piñon-Juniper Woodland VTs by very steep slopes and relatively low cover of larger sized rock covers (boulder, rock). PJW-M was a common VT in the study area, encountered in $21 \%$ of all plots.

\section{Descriptions of VTs Not Associated with the Target Species}

The 6 VTs not associated with A. albens or E. o. ssp. vineum were also described by dominant and indicator species, means of the thirieen environmental variables used to describe stratifications, and by means of vegetational variables including total species richness, mean species richness, Shannon's diversity index, total overstory and shrub covers, and total canopy height (Tables 23-28). Comprehensive species lists were also compiled for each VT not associated with the target species (Appendices 16-21). Quantitative information was used to qualitatively describe these $6 \mathrm{VTs}$ as follows:

Blackbrush Scrub-Piñon Woodland Transition ( $n=8$ ): BBS-PW had the third lowest miean elevation, shared elements of both BBS and higher elevation Piñon-Juniper Woodland communities (PJW-M, PJW-F, PJW-Y), but differed primarily by having only trace amounts of Juniperus osteosperma cover. It was dominated by Pinus monophylla and Yucca brevifolia in the overstory layer, 
Table 23: Dominant and indicator species of the 6 major vegetation types not associated with the target species, including dominant overstory species (O: mean cover $>5 \%)$, shrub species ( $\mathrm{S}$ : mean cover $>3 \%$ ), bunchgrass species ( $\mathrm{B}$; mean cover $>3 \%$ ) and herb species ( $\mathrm{H}$ : Inean abundance $>1.0$ and occurring in only one VT) are listed. Indicator species are from TWINSPAN. Pinus monophylla was excluded from this table due to its dominant presence in almost all VTs.

\begin{tabular}{|c|c|c|}
\hline$\overline{\mathrm{VT}}$ & Dominant Species & Indicator Species \\
\hline BBS-PW & $\begin{array}{l}\text { Yucca brevifolia }(O) \\
\text { Coleogyne ramosissima (S) } \\
\text { Eriogonum fasciculatum polifolium (S) } \\
\text { Purshia glandulosa (S) } \\
\text { Phacelia distans }(H)\end{array}$ & Artemisia tridentata (S) \\
\hline PJW-Y & $\begin{array}{l}\text { Juniperus osteosperma (O) } \\
\text { Ceanothus greggii vestitus (S) } \\
\text { Purshia glandulosa (S) }\end{array}$ & $\begin{array}{l}\text { Quercus chrysolepis (O) } \\
\text { Yucca whipplei (S) }\end{array}$ \\
\hline PJW-SLO & $\begin{array}{l}\text { Quercus turbinella }(O) \\
\text { Haplopappus linearifolius }(S) \\
\text { Eriophyllum lanatum }(H) \\
\text { Galium angustifolium }(H)\end{array}$ & $\begin{array}{l}\text { Nolina pamyi }(S) \\
\text { Opuntia basilaris basilaris (S) }\end{array}$ \\
\hline PW-JT & Yucca brevifolia $(O)$ & $\begin{array}{l}\text { Haplopappus linearifolius (S) } \\
\text { Ephedra viridis (S) }\end{array}$ \\
\hline PW-CLO & $\begin{array}{l}\text { Artemisia tridentata (S) } \\
\text { Fremontodendron californica (S) } \\
\text { Purshia glandulosa (S) }\end{array}$ & $\begin{array}{l}\text { Quercus chrysolepis }(O) \\
\text { Amorpha califomica }(S) \\
\text { Ceanothus greggii }(S) \\
\text { Poa fendleriana (B }\end{array}$ \\
\hline YPF-PW & $\begin{array}{l}\text { Pinus jeffreyi }(O) \\
\text { Quercus chrysolepis (O) } \\
\text { Cercocarpus ledifolius (S) } \\
\text { Galiumparishii }(H)\end{array}$ & $\begin{array}{l}\text { Juniperus occidentalis }(O) \\
\text { Eriogonum wrightii }(H) \\
\text { Erysimum capitatum }(H) \\
\text { Monardella linoides }(H)\end{array}$ \\
\hline
\end{tabular}


Table 24: Physical characteristics of vegetation types not associated with the target species including elevation (meters), northness (negative numbers indicate more south-facing sites while positive numbers indicate more north-facing sites), and slope (degrees).

\begin{tabular}{|c|c|c|c|c|c|c|c|}
\hline \multirow[b]{2}{*}{ VT } & \multirow[b]{2}{*}{$\mathbf{N}$} & \multicolumn{2}{|c|}{ Elevation $(\mathrm{m})$} & \multicolumn{2}{|c|}{ Northness } & \multicolumn{2}{|c|}{ Slope(degrees) } \\
\hline & & Mean & SD & Mean & SD & Mean & $\mathrm{SD}$ \\
\hline $\begin{array}{l}\text { BBS-PW } \\
\text { PJW-Y } \\
\text { PJW-SLO } \\
\text { PW-JT } \\
\text { PW-CLO } \\
\text { YPF-PW }\end{array}$ & $\begin{array}{r}8 \\
15 \\
15 \\
14 \\
13 \\
15\end{array}$ & $\begin{array}{l}1772 \\
1857 \\
1885 \\
1949 \\
2017 \\
2141\end{array}$ & $\begin{array}{l}149 \\
197 \\
147 \\
133 \\
132 \\
155\end{array}$ & $\begin{array}{l}-.156 \\
-.193 \\
.199 \\
.168 \\
-.038 \\
.185\end{array}$ & $\begin{array}{l}.75 \\
.50 \\
.50 \\
.35 \\
.59 \\
.48\end{array}$ & $\begin{array}{l}11.5 \\
15.4 \\
17.9 \\
11.3 \\
15.2 \\
16.3\end{array}$ & $\begin{array}{r}4.6 \\
10.4 \\
7.7 \\
14.2 \\
7.0 \\
9.4\end{array}$ \\
\hline
\end{tabular}



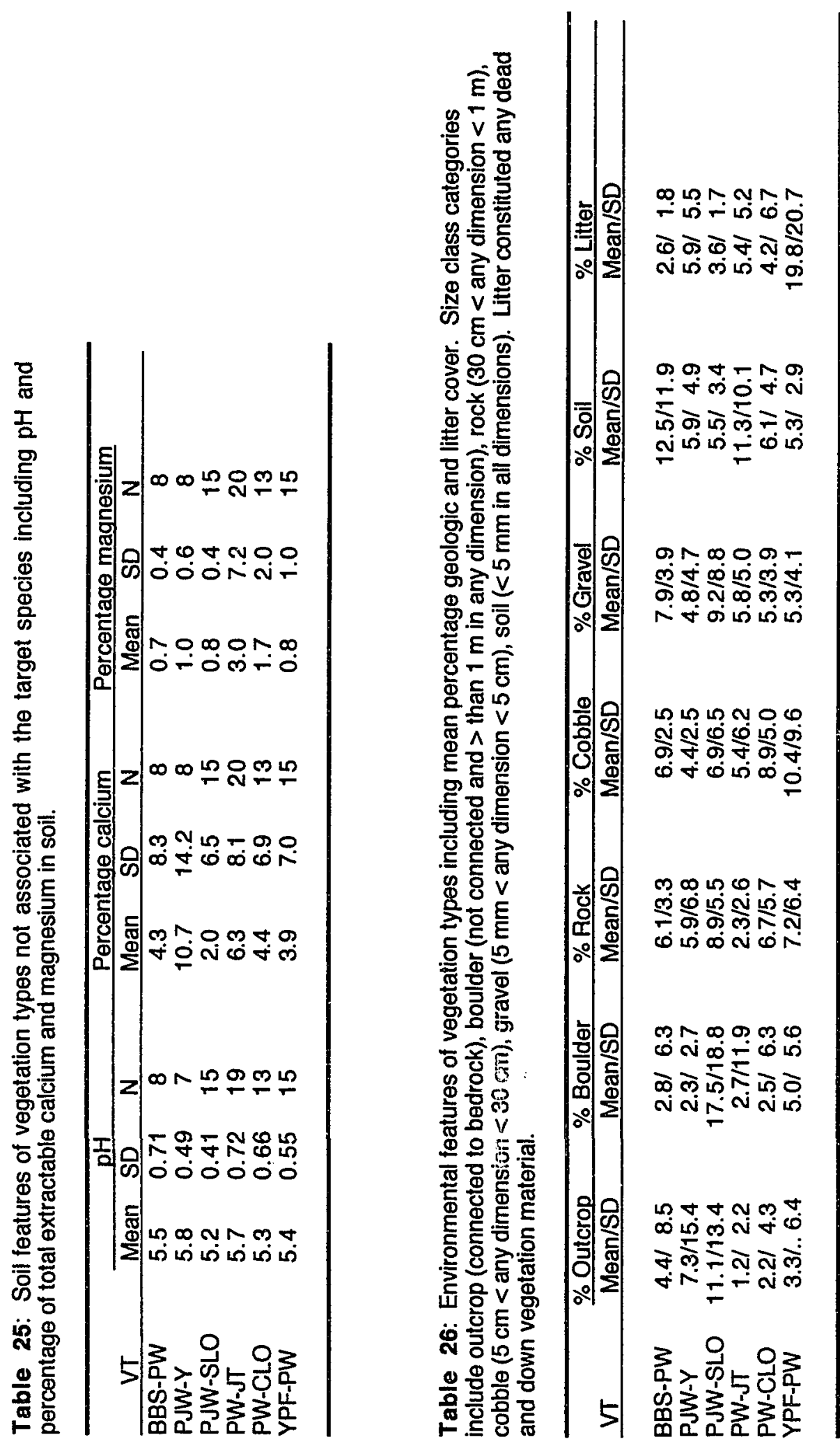
Table 27: Mean species richness, total species richness and Shannon's diversity index by vegetation types not associated with the target species.

\begin{tabular}{lcccc}
\hline VT & N & Mean Richness & Total Richness & Diversity \\
\hline & & & & \\
BBS-PW & 8 & 25.0 & 81 & 1.19 \\
PJW-Y & 15 & 24.3 & 85 & 1.16 \\
PJW-SLO & 15 & 19.9 & 89 & 1.07 \\
PW-JT & 14 & 18.7 & 104 & 1.00 \\
PW-CLO & 13 & 16.8 & 85 & 0.90 \\
YPF-PW & 15 & 15.1 & 79 & 0.91 \\
\hline
\end{tabular}

Table 28: Structural features of vegetation types not associated with the target species including total overstory (canopy) cover (\%), total shrub cover $(\%)$, and mean canopy height $(\mathrm{m})$.

\begin{tabular}{lrrrrrrrrrr}
\hline & \multicolumn{3}{c}{ Total Canopy Cover (\%) } & \multicolumn{3}{c}{ Total Shrub Cover (\%) } & \multicolumn{3}{c}{ Total Canopy Height (m) } \\
\cline { 2 - 11 } VT & Mean & SD & \multicolumn{1}{c}{$\mathrm{N}$} & Mean & SD & N & Mean & SD & N \\
\hline & & & & & & & & & \\
BBS-PW & 15.6 & 11.7 & 8 & 60.4 & 22.4 & 8 & 3.1 & 0.8 & 8 \\
PJW-Y & 23.6 & 11.2 & 6 & 45.9 & 25.0 & 6 & 3.8 & 1.4 & 8 \\
PJW-SLO & 31.8 & 15.2 & 15 & 29.9 & 10.7 & 15 & 3.8 & 1.4 & 15 \\
PW-JT & 22.5 & 17.3 & 8 & 42.5 & 16.7 & 8 & 4.6 & 2.5 & 14 \\
PW-CLO & 41.6 & 26.3 & 13 & 31.9 & 22.9 & 13 & 4.1 & 1.3 & 13 \\
YPF-PW & 44.9 & 15.5 & 15 & 18.5 & 12.4 & 15 & 8.3 & 7.2 & 15 \\
\hline
\end{tabular}


and Coleogyne ramosissima, Eriogonum fasciculatum ssp. polifolium and Purshia glandulosa in the shrub layer. Phacelia distans dominated the herb layer in relative abundance. Artemisia tridentata was an indicator species in the shrub layer. It was primarily distinguished from BBS by a dominant overstory component of Pinus monophylla. However, like BBS, BBS-PW was characterized by relatively xeric sites found on low to moderately sloping foothills and bajadas of southern exposure. Their open character was due to low cover of larger geologic categories (rock, boulder and outcrop) combined with low, sometimes absent, overstory cover, and high shrub cover. BBS-PW was the rarest of all VTs in the study area and was encountered in only $4 \%$ of all plots.

Piñon-Juniper Woodland with Yucca ( $n=15)$ : PJW-Y had the fourth lowest mean elevation and was dominated by Juniperus osteosperma and Pinus monophylla in the overstory layer and Ceanothus greggii ssp. vestitus and Purshia glandulosa in the shrub layer. Quercus chrysolepis was an indicator in the overstory layer and Yucca whipplei in the shrub layer. Although somewhat high in elevation, PJW-Y was on average the most xeric VT based on northness and was found predominantly on carbonate substrates. PJW-Y was a relatively rare VT in the study area, encountered in only $7 \%$ of all plots.

Piñon-Juniper Woodland with Shrub Live Oak $(n=15)$ : PJW-SLO had the fifth lowest mean elevation and was dominated by Pinus monophylla and Quercus turbinella (Shrub Live Oak) in the overstory layer. Typically, the herb Eriophyllum lanatum was found growing on the gravelly granite soils among 
the rocks, along with the shrub Haplopappus linearifolius, and the herb Galium angustifolium. Nolina parryi and Opuntia basilaris ssp. basilaris were indicators in the shrub layer. PJW-SLO was found predominantly on noncarbonate deposits In fact, the Shrub Live Oak (Quercus turbinella) was observed to grow exclusively on non-carbonate sites. In general, this VT was also found on steep, rocky sites. PJW-SLO was a relatively rare VT in the study area, encountered in only $7 \%$ of all plots in the study area.

Piñon Woodland with Joshua Tree ( $n=20$ ): PW-JT had the third highest mean elevation and represented the lowest Piñon Woodland VT. It was dominated by Pinus monophylla and Yucca brevifolia in the overstory layer and had no dominant shrub species. Haplopappus linearifolius and Ephedra viridis were indicators in the shrub layer and the shrub Salvia dorrii was often present. PW-JT was found at more exposed and slightly lower elevations than PW-CLO. PW-JT was one of the less common VTs in the study area, encountered in $9 \%$ of all plots.

Piñun Woodland with Canyon Live Oak $(n=13)$ : PW-CLO had the second highest mean elevation and represented the highest Piñon Woodland VT. It was dominated by Pinus monophylla in the overstory layer and by Artemisia tridentata, Fremontodendron californicum and Purshia glandulosa in the shrub layer. Indicator species for this VT included Quercus chrysolepis (Canyon Live Oak) in the overstory layer, Amorpha californica and Ceanothus greggii ssp. vestifus in the shrub layer and the bunchgrass Poa fendleriana. PW-CLO occurred in somewhat more protected sites, often in ravines or canyons. The 
presence of Ceanothus greggii ssp. vesitus at some sites in this VT indicated relatively recent burns. PW-CLO was the second rarest VT in the study area, encountered in only $6 \%$ of all plots.

Yellow Pine Forest-Piñon Woodland Transition ( $n=15)$ : YPF-PW was the highest elevation VT in the study area. This VT differed from all other VTs by the presence and dominance of Pinus jeffreyi (Jeffrey Pine) in the overstory layer. YPF-PW was also dominated by Quercus chrysolepis in the overstory layer and by Cercocarpus ledifolius in the shrub layer, but neither were unique to this VT. Juniperus occidentalis (Western Juniper) was an indicator in the overstory layer and Erysimum capitatum was an indicator in the herb layer. Eriogonum wrightii and Monardella linoides were both relative abundance dominants and indicator species in the herb layer. This VT also had the highest overstory cover, the highest canopy height, the largest DBH, and highest litter cover of all the VTs. Percentage litter cover was high due to the thick pine needle mat dropped by the Jeffrey Pine. YPF-PW was a relatively rare VT in the study area, encountered in only $7 \%$ of all plots.

All VTs involving Piñon Woodlands, including PW-JT, PW-CLO, and YPFPW, were found predominantly on non-carbonate substrates which were higher in elevation than the mid-elevation carbonate substrates. Generally, as mean elevation increased among VTs, larger trees began to dominate the overstory and fewer types of shrub and herb species were observed in the understory. These VTs were characterized by relatively low mean species richness and diversity. 


\section{CHAPTER 4}

\section{Discussion}

Little is known about the habitat features associated with $A$. albens and E. o. ssp. vineum. In fact, almost no ecological information is known about the target species except that they are rare and that populations appear limited to carbonate surface deposits on the Big Bear Ranger District of the San Bernardino National Forest (Barrows 1988; Krantz 1979). During the past fifteen years field surveys have been conducted yet gathered data has been limited to target species population locations and general population densities (Neel 1993). However, hypotheses regarding the ecology of the target species were formed during these field surveys. This thesis was the first quantitative testing of these hypotheses and it presents the first quantitative ecological information available on the target species. 


\section{Stratification Comparisons}

\section{Carbonate and Non-Carbonate Substrates}

Results from this thesis refuted the first null hypothesis which stated that the target species were not restricted to carbonate substrates in the study area. Every occurrence of both target species was found on carbonate substrates, particularly those which were relatively high in calcium content among all carbonate sites. These results demonstrated that $A$. albens and $E$. 0 . ssp. vineum were clearly limited to carbonate substrates in the study area. The existence of characteristic species common to both carbonate and target species habitats, correlation of target species distributions to high soil calcium content, correlation of target species ordination scores to high soil calcium, and associations of the target species with carbonate-affiliated vegetation types, aii provide a strong, quantified argument for carbonate-endemism of the target species in the study area.

Additional vegetational and environmental differences between the general carbonate habitats associated with the target species and the noncarbonate habitats not associated with the target species were also found. These findings served to falsify the second null hypothesis which stated that there were no significant differences between carbonate and non-carbonate sites. The carbonate and non-carbonate substrates supported distinct plant assemblages including the target species, as further evidenced by 23 species characteristic of carbonate substrates and 24 species characteristic of non- 
carbonate substrates, as well as the 27 species exclusive to carbonate substrates and 28 species exclusive to non-carbonate substrates. In addition, vegetation types classified on carbonate soils were distinguishable from those classified on non-carbonate soils.

Mechanisms influencing the differences in vegetation on and off carbonate substrates, including the restriction of the target species to carbonate substrates, are not clear. However, vegetational differences may be related to observed differences in soil chemistry, including $\mathrm{pH}$, and soil calcium and soil magnesium content. This supposition is supported by a number of studies which have attributed observed differences in vegetation on and off carbonate substrates to differences in soil properties (Neely and Barkworth 1984; Wentworth 1981; Marchand 1973; Kruckeberg 1969). Vegetational differences on and off carbonate substrates in this thesis may also be related to observed differences in soil texture. Fine geologic cover materials, including gravel and soil, were found to occur in significantly greater amounts on non-carbonate substrates in this study, and may have played a role in limiting the 47 species displaying significant differences in cover and abundance between the two substrate types.

Physical differences between the two substrate types may also have influenced vegetation, including the target species. For example, the relatively steep slopes found on carbonate substrates, as compared to non-carbonate, may have influenced the distribution of E. o. ssp. vineum which was commonly found on relatively steep sites. 
Sites Occupied by Astragalus albens

Findings from this thesis also refuted the third null hypothesis which stated that significant environmental and vegetational differences do not exist between sites occupied and unoccupied by $A$. albens. The significant environmental and vegetational differences found between sites occupied by $A$. albens and carbonate sitesunoccupied by $A$. ablens, indicated that $A$. albens was not only restricted to carbonate sites, but to a particular subset of carbonate sites within available carbonate-based habitats. Vegetational differences between the two stratifications included differences in mean species richness and Shannon's diversity indices, as well as characteristic species and association of $A$. albens with only 3 out of 5 carbonate-affiliated vegetation types.

Characteristic and indicator species primarily distinguished $A$. albensoccupied sites from $A$. albens-unoccupied sites. There were 13 species characteristic of sites supporting $A$. albens and 4 species which were indicators for carbonate sites not supporting $A$. albens. Past field observations have found a variety of species in association with $A$. albens, including Pinus monophylla, Juniperus californica, Yucca brevifolia, Coleogyne ramosissima, Cercocarpus ledifolius, Astragalus leucolobus, Erigeron parishii, and E. o. ssp. vineum (California Native Plant Society Status Report 1988). None of these species were found to be specifically associated with the $A$. albens in this thesis. Instead, the species mentioned above were found to be indicative of total available carbonate habitat, and not specific to, but occasionally occurring in sites occupied by $A$. albens. 
Findings from this study suggested that mechanisms influencing the restriction of $A$. albens to certain carbonate sites within available carbonate are related to soil chemistry, soil texture, and general topographic site features. For example, significantly higher soil calcium, higher litter cover, lower slope and lower elevation were found in sites supporting $A$. albens compared to sites not supporting $A$. albens. In addition, $A$. albens was associated with BBS, PJW-BB, and PJW-F, all characterized by relatively low slopes and lower elevations, affirming the possible influence of these environmental characteristics on the target species' distribution.

This thesis validated previous finding that sites occupied by $A$. albens contained a higher percentage litter cover than carbonate sites not occupied by A. albens (Barrows 1988). Higher litter cover may have been a result of the significantly higher overstory and shrub cover observed in unoccupied carbonate habitat. Furthermore, $A$. albens and associated characteristic species may occur in carbonate sites containing lower overstory cover and possessing a generally more open character.

Sites Occupied by Eriogonum ovalifolium ssp. vineum

Findings did not support the fourth null hypothesis which stated that significant environmental and vegetational differences do not exist between sites occupied by $E$. 0 . ssp. vineum and carbonate sites not occupied by $E$. $o$. ssp vineum. As in the case of $A$. albens, the significant environmental and vegetational differences found between sites occupied by $E$. 0 . ssp. vineum and 
carbonate sites unoccupied by E. o. ssp. vineum, indicated that $E$. o. ssp. vineum was not only restricted to carbonate sites, but to a particular subset of carbonate sites within available carbonate-based habitats. Vegetational differences between the two stratifications were seen in differences in mean species richness, characteristic species, and association of E. 0 . ssp.vineum with only 2 out of 5 carbonate-affiliated vegetation types.

Characteristic and indicator species primarily distinguished sites occupied by $E$. 0 . s.sp. vineum and carbonate sites unoccupied by $E$. 0 . ssp. vineum. However, there were relatively few species characteristic of sites supporting $E$. o. ssp.vineum compared to those found for sites supporting $A$. albens : only 4 species characteristic of sites supporting E. o. ssp. vineum and 4 species characteristic of carbonate sites not supporting E. 0 . ssp. vineum were found. Phacelia douglasii was the only indicator species for sites occupied by E. o. ssp.vineum. Two other species, Arabis shockleyi and Cryptantha confertiflora, were found frequently in E. o. ssp.vineum plots. Although they were not found to be indicator species in this thesis, they have long been thought to be closely associated with E. o. ssp.vineum (Neel 1993).

This thesis' results indirectly showed that mechanisms influencing the restriction of $E$. 0 . ssp. vineum to particular sites within available carbonate may be partially related to soil chemistry, soil texture and general site topographic features. For example, significantly higher soil calcium, higher outcrop cover, and steeper slopes were found in sites supporting E. o. ssp. vineum compared to carbonate sites not supporting E. o. ssp. vineum. Higher soil calcium in E. $O$. ssp. vineum habitat may be the single most important factor determining this target species' distribution in available carbonate habitat. Ordination provided 
further support for this idea, graphically revealing that $E$. o. ssp. vineum habitat was restricted to the portion of carbonate sites containing relatively high soil calcium content.

\section{Implications for Conservation and Restoration}

The dimensions of plant endangerment in California continue to increase despite extensive conservation efforts (Smith 1986). Regulation of development projects, limited conservation activities, mitigation of project impacts and preservation of pristine habitats are not enough to adequately protect plant biodiversity (Berger 1990; Devall and Sessions 1985). Restoration efforts supplementing preservation and conservation activities are needed to ensure the continued survival of endangered plants and the protection of habitats upon which they depend (Barbour 1993; Berger 1990).

Restoration, in general, involves the intentional replication of a native, historic ecosystem at a site which has been altered from that condition (Society of Ecological Restoration 1991). In the case of rare plant habitat restoration, efforts usually focus on recreating a habitat which closely mimics the natural habitat in which the species in question has evolved and persisted through time (Jordan et al. 1988). Replacing the full complement of biotic and abiotic features of rare plant habitat is necessary, in order to emulate the structure, function, and dynamics of the specified habitat (Society of Ecological Restoration 1991). By restoring important environmental and vegetational features of the habitat being recreated, such as dominant species and soil 
chemistry, ecological functions important to the survival of the rare plants may also be restored.

Complete restoration of vegetational and environmental features of rare plant habitat is clearly a complex task requiring detailed descriptions of sites to be restored (Cairns 1980). This thesis provides extensive quantitative descriptions of the plant communities associated with the target species and neighboring communities. This thesis also provides extensive quantitative information regarding the environmental conditions which support the plant communities which are directly and indirectly associated with $A$. albens and $E$. o. ssp. vineum. Both vegetational and environmental descriptions provided in this thesis are important to future restoration activities in the study area.

Dominant overstory and shrub species are among the most important species to use in revegetation. The cover, size, and abundance of dominant species at particular sites in the study area may be important factors in making the site suitable for native species, including $A$. albens and $E$. 0 . ssp. vineum. Herbs such as Cryptantha confertiflora, characteristic of E. o. ssp. vineum habitat, and Parishella californica, characteristic of $A$. albens habitat, may also be important to the target species by providing favorable seedling microsites (moisture, protection from granivory, important microflora), or attracting common pollinators or seed dispersal agents (granivores, herbivores). Less direct effects, such as microsite enhancement, may be as important as more direct effects, such as overstory shading, in the interactions of a particular habitat (Odum 1992).

Characteristic as well as indicator species also provide a means by which to monitor signs of stress during reintroductions of the target species. 
Usually, affects of environmental stress are first seen at the population level, often affecting sensitive species (Odum 1992), such as $A$. albens and $E .0$. ssp.vineum. However, depending on the type of environmental stress, different species may show signs of stress sooner than others. If significant functional redundancy exists between target species and characteristic or indicator species, signs of stress observed first in the characteristic and indicator species may be an early warning of stress to the target species, which has not yet been expressed. In this case, stress to a characteristic or indicator species could signal needed changes in site management techniques aimed at reducing environmental stress.

Descriptions of environmental features of sites associated with the target species also have applications in habitat restoration. Reclamation requirements typically include standards for soil chemistry and slope recontouring. The data from this thesis can be used to establish benchmarks for assessing success of a reclamation project. Means and associated standard deviations of environmental variables quantify these benchmarks and provide a range of successful variable levels. For example, if soil calcium levels are to be restored at a site in which $A$. albens is to be reintroduced, restoration plans would call for approximately 14 to $28 \%$ total extractable calcium in the soil (mean=21.2, $\underline{\mathrm{SD}}=7.8$ ). In addition, slope and aspect data will be especially helpful in setting guidelines for recontouring, elevation ranges will aid in choosing appropriate reintroduction sites, and soil cover categories will guide the replication of surface characteristics at sites to be restored.

The quantitative and qualitative descriptions of vegetation types provide additional information about target species habitats which can be used in future 
conservation and restoration, for example, the vegetation classification which will aid in conservation of vegetation types in the study area, including those associated with the target species. Dominant, characteristic and indicator species will help identify vegetation types in aerial photographs and in the field during mapping of vegetation types, the next phase of this project. Vegetation type mapping on the Big Bear Ranger District will be facilitated by using geographic information systems (GIS), additional field studies, and groundtruthing. GIS mapping of vegetation in the study area including vegetation types, target species populations, substrate types, and mineral claims will allow

more detailed analyses of cumulative impacts to the target species habitat. GIS mapping will also facilitate the determination of sites for future preservation of target species habitat in refugia.

\section{Limitations of Findings}

The findings from this thesis were limited in three respects. The primary limitation was use of an incomplete data set during sampling. The serendipitous discovery of several new target species populations indicated that maps of target species populations were incomplete, even though the area had been surveyed repeatedly during the past 15 years (Neel 1993; Barrows 1988; Krantz 1979). It is possible that the dimensions of the target species populations have changed, new populations have appeared or older populations have disappeared since the last field documentation. By not 
sampling unknown and unmapped populations, important and unique features of the target species habitat may have been missed.

The second limitation of the findings from this thesis originated in the comparison of carbonate and non-carbonate sites. This comparison found significant differences between the two substrate-based habitats but was biased through the analytical design. Specifically, all $A$. albens and E. o. ssp.vineum -centered plots $(\underline{n}=58)$ were included in the carbonate stratification, with all the random carbonate plots $(\underline{n}=88)$. As a result, environmental and vegetational data from the carbonate stratification disproportionately represented sites occupied by the target-species, and less accurately represented random carbonate sites. However, the purpose of this comparison was to discern further differences between carbonate-based habitats associated with the target species and non-carbonate based habitats not associated with the target species. Therefore, lumping of the target species-centered plots into the carbonate stratification made the differences between habitat features of the non-carbonate sites and the target species sites more evident.

Finally, there are limitations to the values found for environmental and vegetational features of sites characterized. For the most part, values of environmental and vegetational features characterizing the target species and associated habitats had considerable ranges. Because of this, the quantitative data presented in this thesis will serve only as broad-scale baseline information during restoration projects. Additional, site-specific sampling will be needed to augment the more general characterizations presented here. Information from this thesis and additional site-specific studies will be used in conjunction with 
the Big Bear Rariger District's reclamation standards for developing revegetation plans for mining operations.

\section{Summary and Conclusions}

Astragalus albens and Eriogonum ovalifolium ssp. vineum were clearly restricted to carbonate deposits in the study area. The occurrence of the target species on only carbonate soils, target species sites containing species characteristic of only carbonate-based habitats, correlations of target species occurrences to high soil calcium content, and associations of target species with carbonate-affiliated vegetation types all provide a strong, quantified argument for their carbonate-endemism in the study area. Furthermore, due to the area sampled, which is approximately one-half of the total range of the target species distribution, findings from this thesis also suggest that the target species are endemic to carbonate deposits throughout their range in the San Bernardino Mountains.

The habitat in which these two rare plants found was also found to be rare. A. albens and E. o. ssp. vineum were further restricted to particular carbonate sites within all the available carbonate sites in the study area. Sites occupied by the target species were characterized by certain vegetational features, including dominant, characteristic and indicator plant species, and certain environmental features, including high soil calcium. Association of the target species with specific carbonate-affiliated vegetation types underscored the finding that the target species were found in pockets of unique carbonate- 
based habitat which were vegetationally and environmentally unique from surrounding carbonate sites not supporting the target species.

The finding that habitats supporting $A$. albens and $E .0$. ssp.vineum were rare, even within carbonate substrates, should explicate the need for conservation and restoration of their habitat. Vegetational and environmental features described should be used as guides during replication of these rare habitats. Furthermore, the exact ranges and levels of environmental features and exact replication of species covers, compositions, and abundances during restoration projects may be ecologically essential to the successful reestablishment and survival of the target species. 


\section{References}

Acosta, A., S. Diaz and M. Cabido. 1990. Patch structure in natural grasslands of Cordoba Mountains (Argentine) in relation to different rock substrates. COENOSES6(1): 21-27.

Allen, E.B. 1989. The restoration of disturbed arid landscapes with special reference to mycorrhizal fungi. J. of Arid Environments 17:279-286.

Ashton, P.S. 1992. Species richness in plant communities. In, Conservation Biology, eds. P.L. Fiedler and S.K. Jain, pp. 3-22. New York: Chapman and Hall.

Ayensu, E.S. 1980. Assessment of threatened plant species in the United States. In The biological aspects of rare plant conservation, ed. H. Synge, 19-58. New York: Wiley.

Barbour, M.G., Pavlik, B., F. Drysdale and S. Lindstrom. 1993. California's changing landscapes: Diversity and conservation of California vegetation. Sacramento, California: California Native Plant Society.

Barbour, M.G., and J. Major. 1990. Terrestrial vegetation of California. California Native Plant Society: Special Publication Number 9.

Barbour, M.G., Burk, J.H., and W.D. Pitts. 1987. Terrestrial plant ecology. Menlo Park, California : Benjamin/Cummings Publishing Co., Inc.

Barrows, K., Brown, H., Johnson, C, Krantz, T., Shumway, D, Thorne, R. 1992. U.S. Fish and Wildlife Service hearing on the proposed listing of five carbonate endemic plant species, Astragalus albens, Erigeron parishii, Eriogonum ovalifolium ssp. vineum, Oxytheca parishii var.goodmaniana, Lesquerella kingii ssp.bernardinus, in the San Bernardino Mountains. June 3, 1992. San Bernardino County Courthouse.

Barrows, K. 1988. Field surveys of Astragalus albens, Erigeron parishii, Eriogonum ovalifolium ssp. vineum, Oxytheca parishii var.goodmaniana, Lesquerella kingii ssp.bernardinus, for the San Bernardino National Forest.

Bauder, E.T. and A. Larigauderie. 1991. Rehabilitation success and potential of Mojave and Colorado desert sites. A report to the California Department of Parks and Recreation by the authors at the Department of Biology, San Diego State University.

Beeson, C.D. 1974. The distribution and synecology of Great Basin pinyon-juniper. M.S. thesis, University of Nevada, Reno.

Berger, J. J. 1990. Environmental Restoration. Covelo, California: Island Press.

Billings, W. D. 1952. The environmental complex in relation to plant growth and distribution. Quarterly Review of Biology 27:251-265.

Borchert, M. and M. Hibbert. 1984. Gradient analysis of a north slore rriontane forest in the western Transverse Ranges of southern California. Madrow 31(3): 129-139. 
Bowler, P.A. 1989. Riparian woodland: An endangered habitat in southern California. In, Endangered plant communities of southern California: Proceedings of the 15th annual symposium, ed. A. A. Schoenherr, 80-97.

Braun-Blanquet, J. 1932. Plant sociology; the study of plant communities. New York and London : McGraw Hill.

Brown, H. 1992. Geologic substrate maps for the San Bernardino Mountains. Lucerne Valley: Pleuss-Stautfer, Inc.

Cairns, J. 1980. The Recovery Process in Damaged Ecosystems. Ann Arbor, Michigan: Ann Arbor Science.

. 1986. Restoration, reclamation and regeneration of degraded or destroyed ecosystems. in Conservation Biology: the science of scarcity and diversity, ed. M. E. Soule, 465-484. Sunderland, MS: Sinauer Associates.

California Native Plant Society. 1988. Status report on Astragalus albens. Sacramento, California: California Native Plant Society.

Carroll, R.C. 1992. Ecological mangement of sensitive natural areas. In, Conservation Biology, eds. P.L. Fiedler and S.K. Jain, pp. 347-372. New York: Chapman and Hall.

Center for Plant Conservation. 1988. A survey of the most critically threatend plant species in the United States. St. Louis, Missouri.

1991a. Database of the Center for Plant Conservation. St. Louis, Missouri.

Clements, F.E. 1920. Plant indicators: the relation of plant communities to process and practice. Carnegie Institution of Washington Publ. 290. Washington, D.C.: Carnegie Institution of Washington.

Davis, S.D., Droop, S.J.M., Gregerson, P. Henson, L., Leon, C.S., Lambein Villa-Lobos, J, Synge, H. and J. Zantovska. 1986. Plants in danger: What do we know? International Union for Conservation of Nature, Gland, Switzerland.

Devall, B. and G. Sessions. 1985. Deep Ecology. Salt Lake City: Gibbs Smith.

DeVelice, R., J.W. DeVelice and G.N. Park. Gradient analysis in nature reserve design: A New Zealand example. Conservation Biology 2(2):206-217.

Del Moral, R. 1982. Control of vegetation on contrasting substrates: herb patterns on serpentine and sandstone. Am. J. Bot. 69:227-238.

. 1983. Competition as a control mechanism is subalpine meadows. Amer. J. of Bot. 70:232-245.

Du Preez, P.J. 1992. The classification of the vegetation of Korannaberg, eastern Orange Free State, South Africa. I. Afromontane fynbos communities. S. Afr. J. Bot. 58(3):165-172. 
Elias, T.S. 1986. Conservation and management of rare and endangered plants. Proceedings from a conference of the California Native Plant Society, November 1986.

Ellenberg, H. 1958. Bodenreaktion (einschlieblich Kaltfrage). In Handbuch der Pflanzephysiologie, vol. 4, ed. W. Ruhland, 638-708. Berlin: Springer-Verlag.

Endangered Species Act of 1973. 16 U.S.C. $§ 1531$ et seq.

Erhlich, P.A. 1992. Population biology of checkerspot butterflies and the preservation of global diversity. OIKOS 62:6-12.

Falk, D.A. 1987. Integrated conservation strategies for endangered plants. Nat. Areas J. 7:118-123.

1990b. Integrated strategies for conserving plant genetic diversity. Annals Missouri Bot. Gard. 77:36-47.

1991a. Restoring the future, discovering the past. Restoration and Management Notes 8:71-72.

1992. From conservation biology to conservation practice: Strategies for protecting plant diversity. In, Conservation Biology, eds. P.L. Fiedler and S.K. Jain, pp. 397-431. New York: Chapman and Hall.

Falk, D.A. and K.E. Holsinger. 1991. Genetics and conservation of rare plants. New York: Oxford University Press.

Fiedler, P.L. and S K. Jain. 1992. Conservation biology. New York: Chapman and Hall.

Gauch, H.G. 1977. A comparative study of reciprocal averaging and other ordination techniques. J. Ecol. 65:157-174.

General Mining Act of 1872. 30 U.S.C. $\$ 22$ et seg.

Gleason, H.A. 1926. The individualistic concept of the plant association. Bulletin of the Torrey Botanical Club 53:1-20.

Goldin, A. 1976. Effects of limestone soils on plant distribution in the Garnet Mountains, Montana. M.S. Thesis. University of Montana, Missoula.

Goldsmith, F.B. 1991. Monitoring for conservation and ecology. New York: Chapman and Hall.

Grime, J.P. 1962. Factors determining the occurrence of calcifuge species on shallow soils over calcareous substrata. J. of Ecol. 51:375-390.

Grime, J.P. and J.G. Hodgson. 1968. An investigation of the ecological significance of lime-chlorosis by means of large-scale comparative experiments. In Ecoloaical aspects of the mineral nutrition of plants, ed. I.H. Rorison, 67-99. Blackwert Scientific Publications: Oxford and Edinburgh, Great Britain.

Harris, L.D., and G. Silva-Lopez. 1992. Forest fragmentation and the conservation of biological diversity. In, Conservation Biology, eds. P.L. Fiedler and S.K. Jain, pp. 197-237. New York: Chapman and Hall. 
Hickman, J.C. 1993. The Jepson Manual: Higher plants of California. Berkeley, California: The University of California Press.

Hill, M.O. 1979a. TWINSPAN-a FORTRAN program for arranging multivariate data in an ordered two-way table by classification of the individuals and attributes. Ecology and Systematics, Cornell University, Ithaca, New York.

Hill, M.O. 1979b. DECORANA-a FORTRAN program for detrended correspondence analysis and reciprocal averaging. Ecology and Systematics, Cornell University, Ithaca, New York.

Holland, R.F. 1987. Is Quercus lobata a rare plant? Approaches to conservation of rare plant communities that lack rare plant species. In Conservation and management of rare and endangered plant species: Proceedings from a conference of the Califomia Native Plant Society, ed. T.S. Elias, 129-132. Sacramento: The California Native Plant Society.

Holland, R.F. 1986. Preliminary description of the terrestrial natural communities of California. Sacramento, California: California Department of Fish and Game, Nongame heritage program.

Holsinger, K.E. and L.D. Gottlieb. 1991. Conservation of rare and endangered plants: A synthesis. In Genetics and conservation of rare plants, ed. D.A. Falk and K.E. Holsinger, 195-208. New York: Oxford University Press.

Horton, J.S. 1960. Vegetation types of the San Bernardino Mountains. U.S.D.A. Forest Service, Pacific SW Forest and Range Exp. Station, Technical Paper 44, p29.

Hutchinson, T.C. 1967. Lime-chlorosis as a factor in seedling establishment on calcareous soils. A comparative study of species from acidic and calcareous soils and their susceptibility to lime-chlorosis. New Phytologist 66:697-705.

Jackson L.L., McAuliffe, J.R. and B.A. Roundy. 1992. Desert restoration. Revegetation trials on abandoned farmland in the Sonoran Desert lowlands. Restoration and Management Notes 9(2):71-80.

Jensen, D.B. 1986. Concepts of preserve design: what we have learned. In Conservation and management of rare and endangered plants: Proceedings from a conference of the California Native Plant Society, ed. T.S. Elias, 595-603. Sacramento: California Native Plant Society.

Jongman, R.H.G., C.J.F. ter Braak and O.F.R. van Tongeren (1987). Data analysis in community and landscape ecology. Pudoc Wageningen: Center for Agricultural Publishing and Documentation.

Jordan, W.R., Gilpin, M.E. and J.D. Aber. 1987. Restoration ecology. New York: Cambridge University Press.

Jordan, W.R., Peters, R.L. and E.B. Allen. 1988. Ecological restoration as a strategy for conserving biological diversity. Environmental Management 12(1):55-72.

Kay, B.L. and W.L. Graves. 1983. History of revegetation studies in the California deserts. In Environmental effects of off-road vehicles, impacts and management in arid regions, ed. R.H. Webb and H.G. Wilshire, 315-324. Berlin: Springer-Verlag. 
Kenline, G. 1993. Lands and Minerals Officer. San Bernardino National Forest.

Krantz, T. 1979. A botanical investigation of Eriogonum ovalifolium ssp. vineum. U. S.D.A. Forest Service, San Bernardino National Forest, Big Bear Ranger District.

Krantz, T. 1990. A guide to the rare and unusual wildflowers of the Big Bear Valley Preserve. Big Bear, California: Friends of the Big Bear Valley Preserve.

Kruckeberg, A.R. 1954. The ecology of serpentine soils. III. Plant species in relation to serpentine soils. Ecology 35:267-274.

1969. Soil diversity and the distribution of plants, with examples from western North America. Madrono 20:129-154.

Küchler, A W. 1964. The potential natural vegetation of the coterminous United Sates. American Geographical Society Special Publ. no. 36. New York: American Geographical Society.

1977. The map of the natural vegetation of California, In, Terrestrial vegetation of California, ed. M.G. Barbour and J. Major, p909-915. Sacramento, California: The California Native Plant Society.

Lewin, R. 1989. How to get plants into the conservationists' ark. Science 244:32-33.

MacMahon, J.A. 1987. Disturbed lands and ecological theory: an essay about a mutualistic association. In, Restoration Ecology, W.R. Jordan, M.E. Gilpin and J.D. Aber, eds., pp. 221-237. New York: Cambridge Uniersity Press.

Magurran, A.E. 1988. Ecological diversity and its measurement. Princeton, New Jersey: The Princeton University Press.

Marchand, D.E. 1973. Edaphic control of plant distribution in the White Mountains, eastern California. Ecol. 54:233-250.

Matthews, W.S., van Wyk, A.E., and G.J. Bredenkamp. 1993. Endemic flora of the northeastern transvaal escarpment, South Africa. Biol. Conservation 63:83-94.

Maunder, M. 1992. Plant reintroduction: an overview. Biodiversity and Cons. 1:51-61.

Messick, T.C. 1987. Research needs for rare plant conservation in California. In Conservation and management of rare and endangered plants: Proceedings from a conference of the California Native Plant Society, ed. T. S. Elias, pp. 99-108, Sacramento, Califomia : California Native Plant Society.

Minnich, R.A. 1976. Vegetation of the San Bernardino Mountains. In Plant communities of southern California, ed. J. Latting, pp. 99-124. Sacramento, California: California Native Plant Society, Special Publication 2.

Mooney, H.A. 1966. Influence of soil type on the distribution of two closely related species of Erigeron. Ecol. 47(6):950-958.

Mueller-Dombois, $D$. and $H$. Ellenberg. 1974. Aims and methods of vegetation ecology. New York : John Wiley \& Sons. 
Munz, P.A. and D.D. Keck. 1959. z. Los Angeles, California: University of California Press.

Munz, P.A. 1974. A flora of southern Califomia. Los Angeles, California: University of California Press.

Neel, M. 1993. Personal communications with Michael P. Gonella, February 1993 through August 1993. U. S.D.A. Forest Service, San Bernardino National Forest, Big Bear Ranger District.

Neel, M. and K. Barrows. 1988. California Native Plant Society status report on Astragalus albens. U.S.D.A. Forest Service, San Bemardino National Forest, Big Bear Ranger District.

Neel, M. and T. Krantz. 1988-1992. Field surveys of rare plant populations, conducted for the U.S.D.A. Forest Service, San Bernardino National Forest, Big Bear Ranger District.

Neely, E.E. and M.E. Barkworth. 1984. Vegetation on soils derived from dolomite and quartzite in the Bear River Range, Utah: a comparative study. Bulletin of the Torrrey Botanical Club 111(2):179-192.

Noy Meir, I. 1973. Desert ecosystems: environment and producers. Annu. Rev. Ecol. Syst. 4:25-52.

Odum, E.P. 1992. Great ideas in ecology for the 1990s. BioScience 42(7), July/August 1992.

Partridge, T.R. 1992. Vegetation recovery following sand mining on coastal dunes at Kaitorete Spit, Canterbury, New Zealand. Biol. Cons. 61(1):59-71.

Pfizer, Inc. 1992. Marble Canyon quarry mine spoils dump site: Revegetation plan.

Pimm, S.L. 1991. The balance of nature? Chicago: The University of Chicago Press.

Roberts, L. 1989a. Extinction imminent for plants. Science 242:1508.

Ross, M.S., J.J. O'Brien and L.J. Fiynn. 1992. Ecological site classification of Florida Keys terrestrial habitats. BIOTROPICA 24(4):488-502.

Rowlands, P.G. 1980. Recovery, succession and revegetation in the Mojave Desert. In The effects of disturbance on desert soils, vegetation and community processes with emphasis on off-road vehicles: a critical review, eds. P.G. Rowlands, 75-118. U.S.D.I. Special Publ., BLM Desert Plan Staff.

San Bernardino National Forest, Big Bear Ranger District Meteorological Data. 1950-1992.

Shelford, V.E. 1913. Animal communities in temperate America. Chicago: University of Chicago Press.

Smith, Z.G. 1986. Sensitive plant management on the National Forests in California. In Conservation and management of rare and endangered plants: Proceedings from a conference of the California Native Plant Society, ed. T. S. Elias, 61-66. Sacramento, California: The California Native Plant Society. 
Smith, J.P., Jr. and K. Berg. 1988. Inventory of rare and endangered vascular plants of California, 4th ed. Sacramento: California Native Plant Society.

Society of Ecological Restoration. 1991. Society for Ecological Restoration program and abstracts, 3rd annual conference, Orlando, Florida, 18-23 May 1991.

Sokal, R.R. and F.J. Rolf. 1998. Biometry. New York: W.H. Freeman and Company.

Soulé, M.E. 1986. Conservation biology: the science of scarcity and diversity. Sunderland, MS: Sinauer Associates.

Soulé, M.E. and D. Simberloff. 1986. What do genetics and ecology tell us about the design of nature preserves? Biol. Cons. 35:19-40.

Synge, H. 1980. The biological aspects of rare plant conservation. New York : John Wiley \& Sons.

Tadros, T.M. 1957. Evidence of the presence of an edaphobiotic factor in the problem of serpentine tolerance. Ecol. 38:14-23.

The Wilderness Society. 1986. Conserving biodiversity in our National Forests. The Wilderness Society.

Thorne, R. F. 1982. The desert and other transmontane plant communities of southern California. ALISO 10(2):219-257.

Tueller, P.T. and J.E. Clark. 1975. Autecology of pinyon-juniper species of the Great Basin and Colorado Plateau. In Proc. pinyon-juniper ecosystem: a symposium, 27-40. Logan: Utah State University.

Turabian, K.L. 1982. A manual for writers of term papers, theses, and dissertations. Chicago: The University of Chicago Press.

Turner, M.G. 1988. Landscape ecology: the effect of pattern on process. Ann.Rev. Ecol. Syst. 20:171-197.

U.S.D.A. Forest Service Minerals Regulations. 36 CFR $\S 228$ et seq.

U.S.D.I. Fish and Wildife Service. 1990. Policy and guidelines for planning and coordinating recovery of endangered and threatened species.

U.S.D.I. Bureau of Land Management. 1386. Nichol Turk's Head Cactus: Echinocactus horizonthalonius $v$. nicholii habitat management plan.

1986. State of California wilderness status map. Interior Geol. Survey.

U.S. Fish and Wildlife Service. 1991. Endangered and threatened wildlife and plants. 50 C.F.R. \$17.11 and \$17.12. 15 July 1991.

(1992). Hearing on the proposed listing of five carbonate endemic plant species, Astragalus albens, Erigeron parishii, Eriogonum ovalifolium ssp. vineum, Oxytheca parishii var. goodmaniana, Lesquerella kingii ssp. bernaroïnus, in the San Bernardino Mountains. June 3, 1992. San Bernardino County Courthouse. 
Van Leerdam, R.J. Zagt and E.J. Veneklass. 1990. The distribution of ephiphyte growthforms in the canopy of a Colombian cloud-forest. Vegetatio 87:59-71.

Vasek, F.C. and J.F. Clovis. 1976. Growth forms in Arctostaphylos glauca. Amer. J. Bot 63:189-195.

Vasek, F.C. and R.F. Thorne. 1990. Transmontane coniferous vegetation. InTerrestrial Vegetation of California, ed. M.G. Barbour and J. Major, 797-832. Sacramento, Califomia: The California Native Plant Society.

Viceroy Gold Corporation. 1992. First Annual Revegetation Report; Mine Plan and Reclamation Plan. Needles, California.

Virginia, R.A. 1991. Desert restoration: The role of woody legumes. In Environmental restoration, J. Berger ed., 23-30.

Vogl, R.J. and B.C. Miller. 1968. The vegetational composition of the south slope of Mt. Pinos, California. Madroño 19:225-234.

Walter, H. 1979. Vegetation of the earth in relation to climate and the eco-physiological conditions. New York: Springer-Verlag.

Wentworth, T. R. 1981. Vegetation on limestone and granite in the Mule Mountains,Arizona. Ecol. 62(2):469-482.

Westman, W.E. 1987. Implications of ecological theory for rare plant conservation in coastal sage scrub. In Conservation and management of rare and endangered plants: Proceedings from a conference of the California Native Plant Society, ed. T. S. Elias, 133-140. Sacramento, California: The California Native Plant Society.

Whittaker, R. H. 1962. Classification of natural communities. Botanical Review 28:1-239.

Whittaker, R. H. and W. A. Niering. 1968. Vegetation oi the Santa Catalina Mountains, Arizona. IV. Limestone and acid soils. J. of Ecol. 56:523-544.

Wright, R. A. 1978. The reclamation of disturbed arid lands. Albuquerque, NM: University of New Mexico Press.

Wright, R.D. and H.A. Mooney. 1965. Substrate-oriented distribution of Bristlecone Pine in the White Mountains of California. Amer. Midl. Nat. 73:257-284.

Yablokov, A.V. and S.A. Ostroumov. 1991. Conservation of living nature and resources: problems, trends, and prospects. Berlin: Springer-Verlag. 


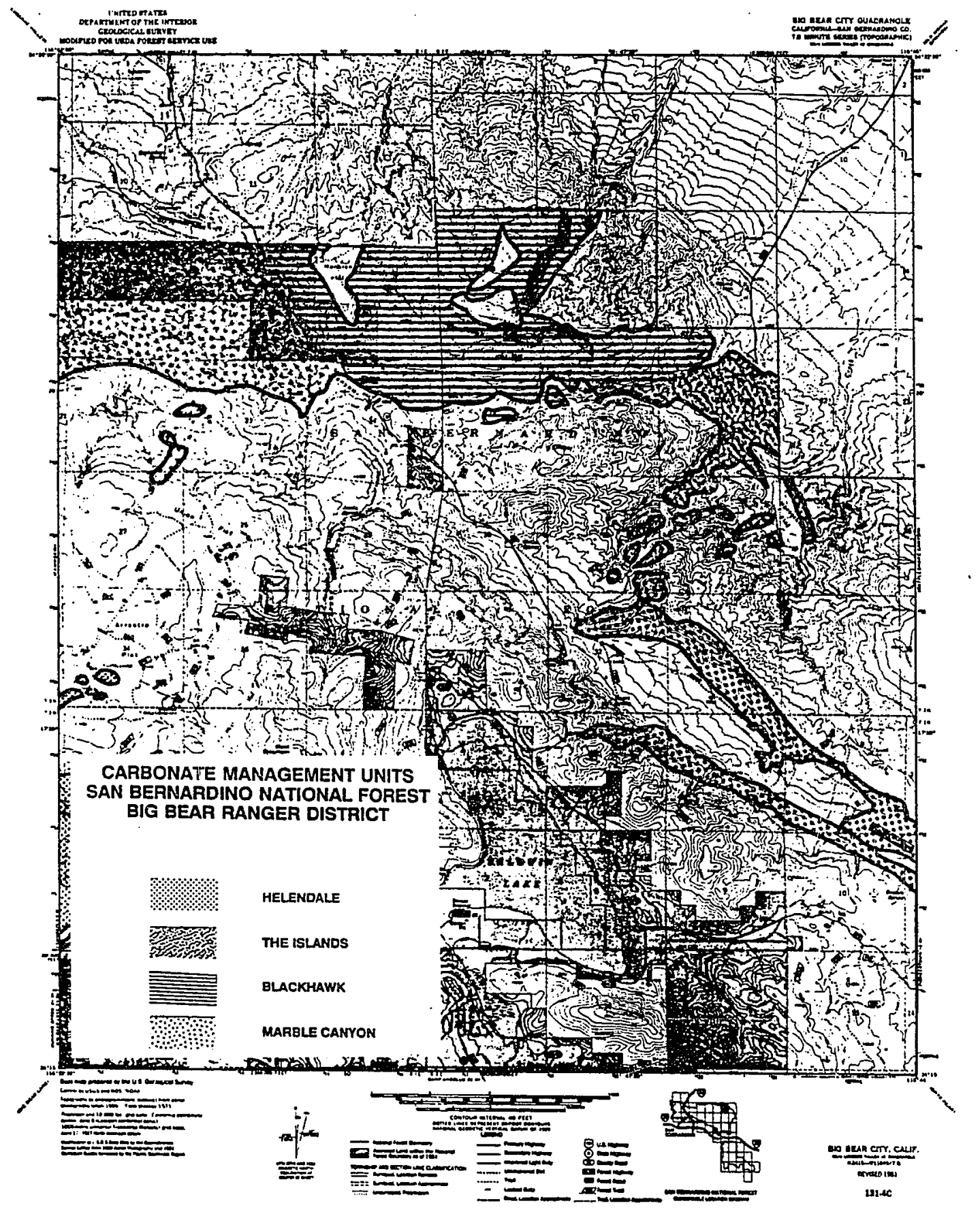

Appendix 1: U.S.G.S. topographic map of Big Bear City quadrangle showing carbonate units on the Big Bear Ranger District. 


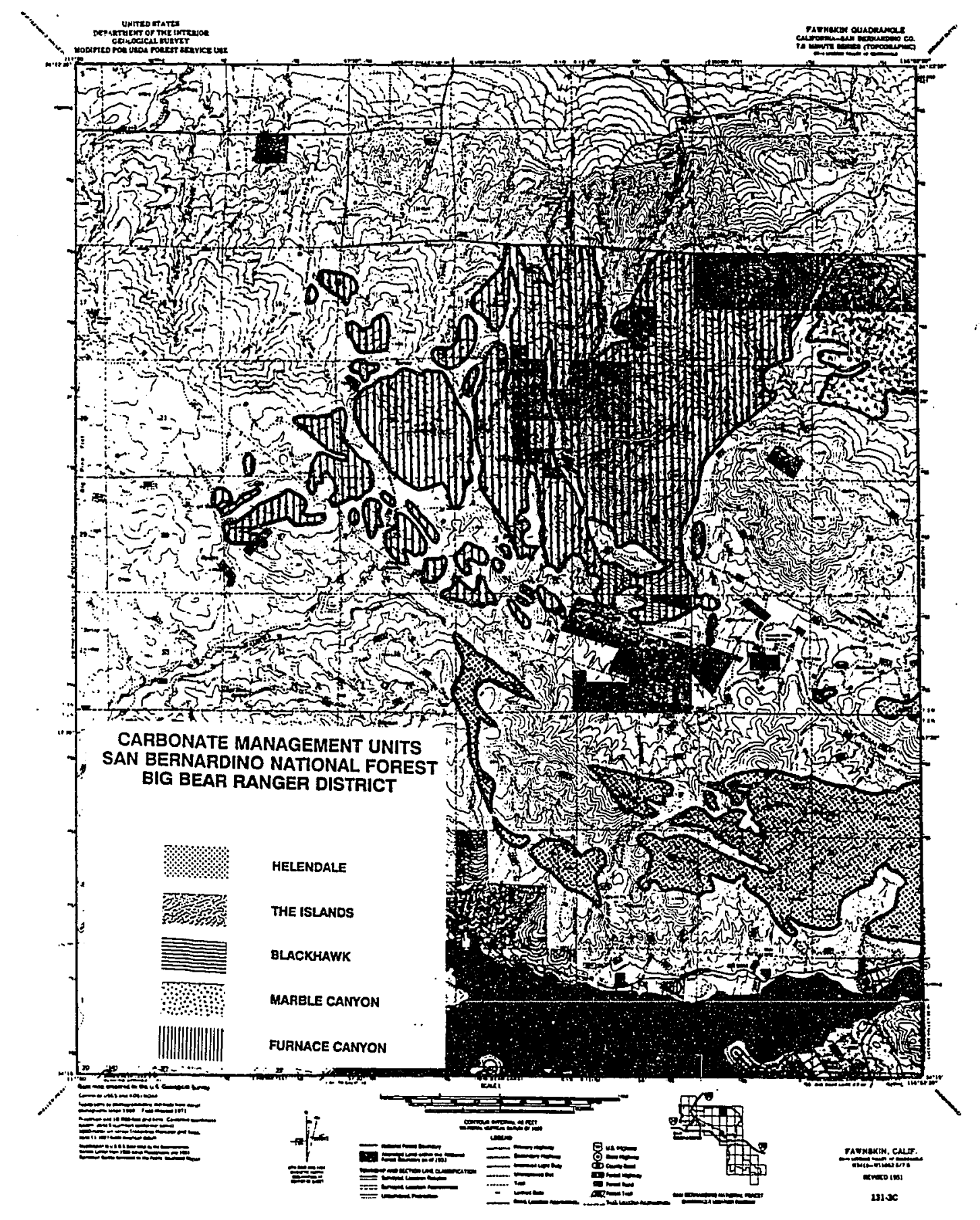

Appendix 2: U.S.G.S. topographic map of Fawnskin quadrangle showing carbonate units on the Big Bear Ranger District. 


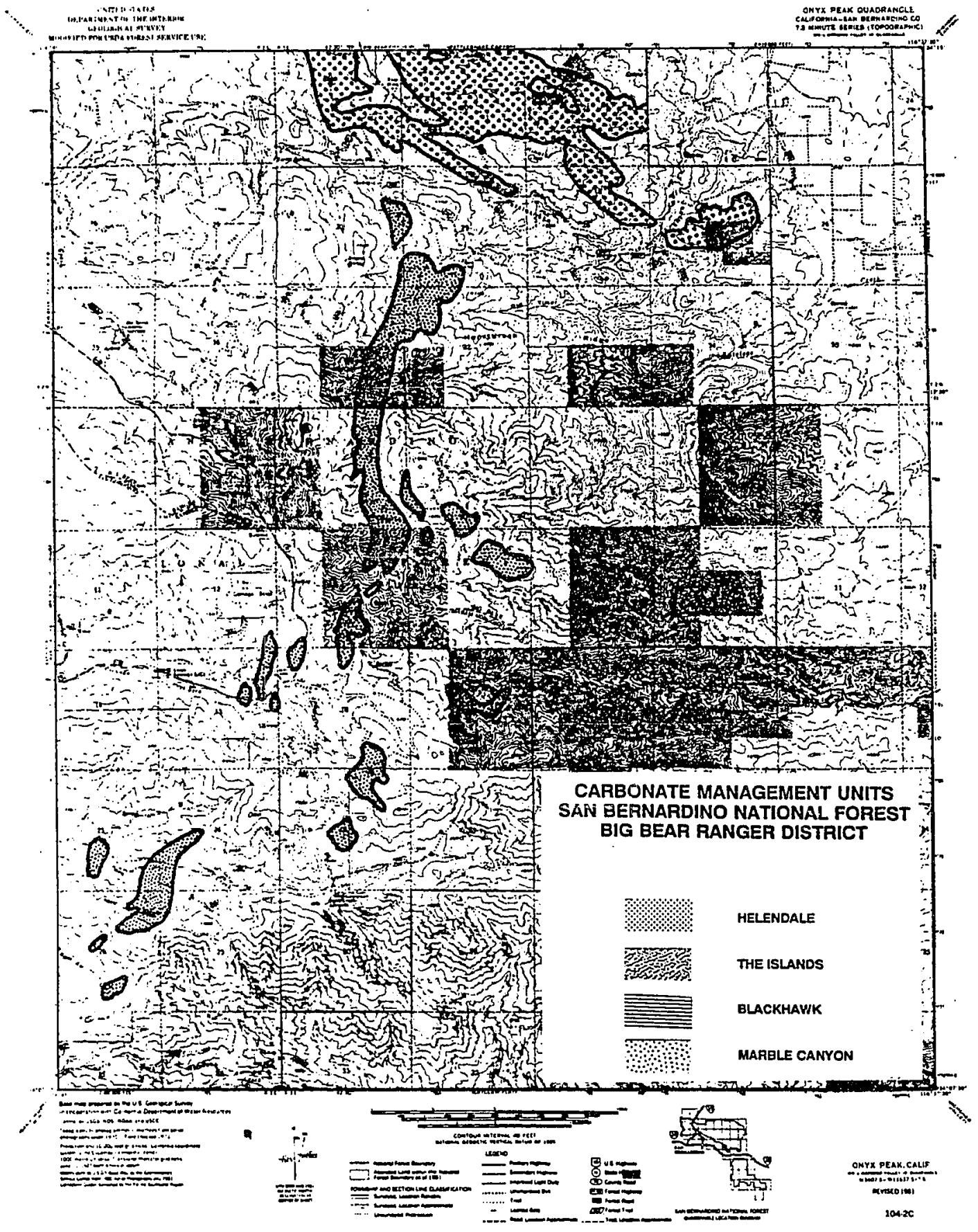

Appendix 3: U.S.G.S. topographic map of Onyx Peak quadrangle showing carbonate units on the Big Bear Ranger District. 


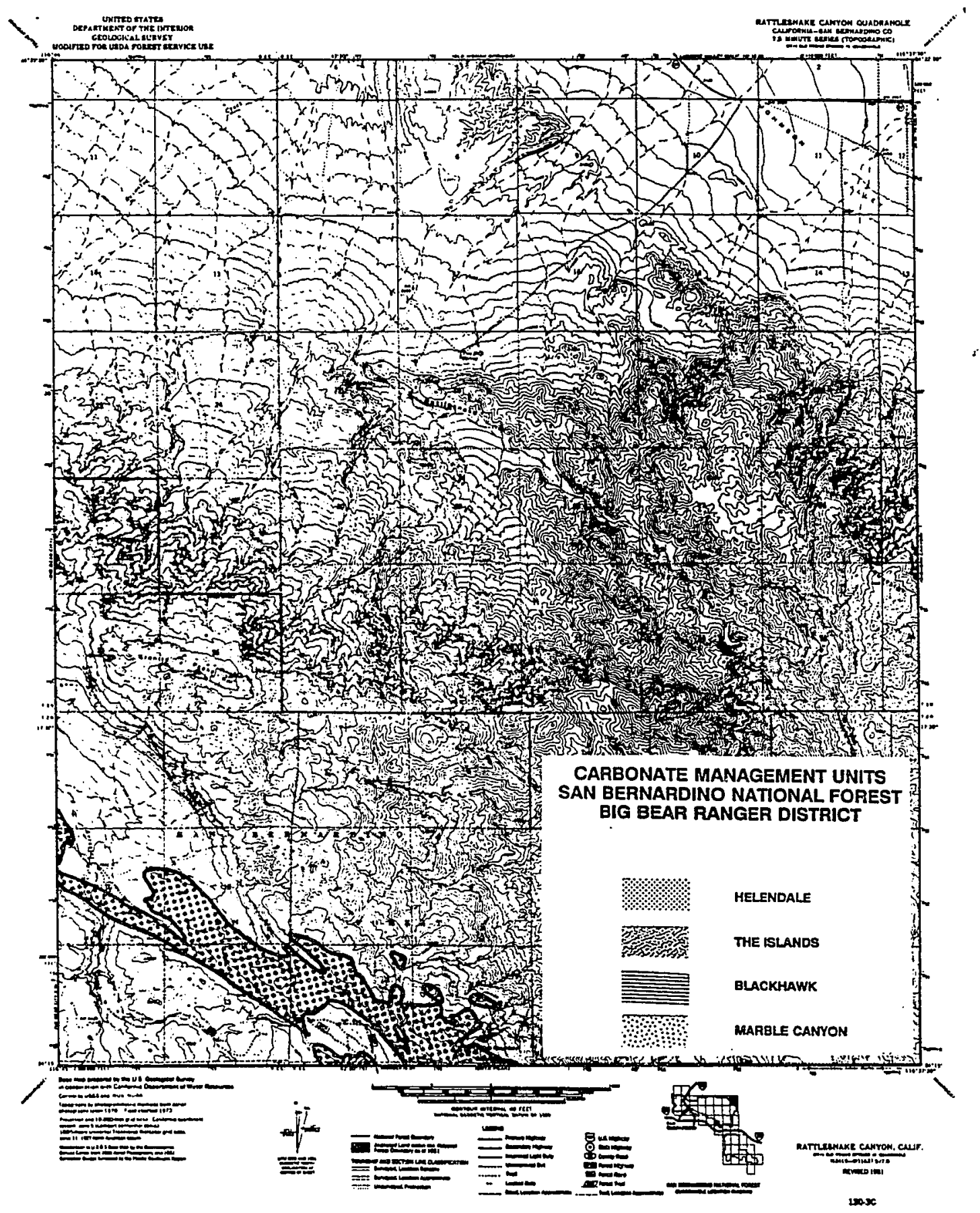

Appendix 4: U.S.G.S. topographic map of Rattlesnake Canyon quadrangle showing carbonate units on the Big Bear Ranger District. 
Appendix 5: Species occurring exclusively in carbonate sites from a comparison of samples of equal size $(n=88)$ comprised of randomly selected plots.

Species

Overstory

Chilopsis linearis

Shrubs

Brickellia desertorum

Eriogonum heermannii

Eriogonum microthecum ssp. corymbosoides

Ferocactus acanthodes lecontei

Forsellesia nevadensis

Glossopetalon spinescens

Grayia spinosa

Larrea tridentata

Lycium andersonii

Machaeranthera tortifolia

Salvia mojavensis

Sphaeralcea ambigua

Yucca whipplei

Perennial Bunchgrasses

Sporobulus cryptandrus

Stipa X Oryzopsis

Vulpia octoflora

Herbs

Abronia nanacovillei

Astragalus coccineus

Cammisonia boothii

Cammisonia sp.

Chaenactis carfloquinia

Cryptantha angustifolia

Cryptantha confertiflora

Cryptantha gracilis

Cryptantha mojavensis

Cryptantha muricata

Cryptantha watsonii

Draba corrugata

Draba cuneifolia

Eriastrum diffusum

Erigeron parishii

Eriogonum inflatum

Eriogonum nidularium

Eriogonum ovalifolium ssp. vineum
Frequency 
Appendix 5: Species occurring exclusively in carbonate sites from a comparison of samples of equal size $(n=88)$ comprised of randomly selected plots.

\begin{tabular}{lc}
\hline Species & Frequency \\
\hline Herbs & \\
\hline Erioneuron pulchellum & 3 \\
Eriophyllurn conferliflorum & 2 \\
Eriophyllum sp. & 4 \\
Eschscholtzia minutiflora & 2 \\
Eucrypta micrantha & 6 \\
Festuca megalura & 2 \\
Galium hallii & 1 \\
Hymenopappus filifolius lugens & 1 \\
Langloisia setosissima & 1 \\
Lepidium nitidum & 1 \\
Lepidium perfoliatum & 2 \\
Lewisia rediviva & 2 \\
Linanthus bigelovii & 1 \\
Linum lewisii & 1 \\
Mentzelia veatchiana & 1 \\
Mimulus bigelovii & 5 \\
Mimulus longiflorus & 1 \\
Mimulus purpureus & 1 \\
Mimulus suksdorfii & 1 \\
Muillamaritima & 7 \\
Nama demissum & 10 \\
Nemacladus longiflorus & 3 \\
Oxytheca parishii var. goodmaniana & 12 \\
Parishella californica & 8 \\
Phacelia cryptantha & 10 \\
Phacelia douglasii & 19 \\
Phacelia parryi & 4 \\
Phacelia sp. & 3 \\
Phlox diffusum & 1 \\
Plagiobothrys hispidulus & 3 \\
Stanleya pinnata & 4 \\
Tricardia watsonii & 1 \\
& \\
\hline &
\end{tabular}


Appendix 6: Species occurring exclusively in non-carbonate sites, from a comparison of samples of equal size $(\underline{n}=73)$ comprised of randomly selected plots.

Oversiory

Abies concolor Juniperus californica

Pinus lambertiana

Populus fremontii

Quercus turbinella

4

Salix exigua

Shrubs

Ambrosia dumosa

Brickellia arguta

Brickellia californica

Cercocarpus betuloides

Chrysothamnus viscidiflorus ssp. viscidiflorus

Ephedra californica

Lepidospartum squamatum

Leptodactylon pungens

Nolina parryi

Opuntia erinacea

Opuntia ramosissima

Rhamnus ilicifolia

Ribes velutinum

Salvia dorrii

Symphorocarpus parishii

Tetradymia axillaris

Tetradymia stenolepis

Perennial Bunchgrasses

Poa incurva

Stipa comata

Vulpia megalura

Herbs

Agrostis semiverticillata

Androsace septrionalis

Antennaria rosea

Arabis dispar

Arabis parishii

Arenaria ursina

Astragalus douglasii

Assiragalus lentiginosus

Astragalus purshii lectulus

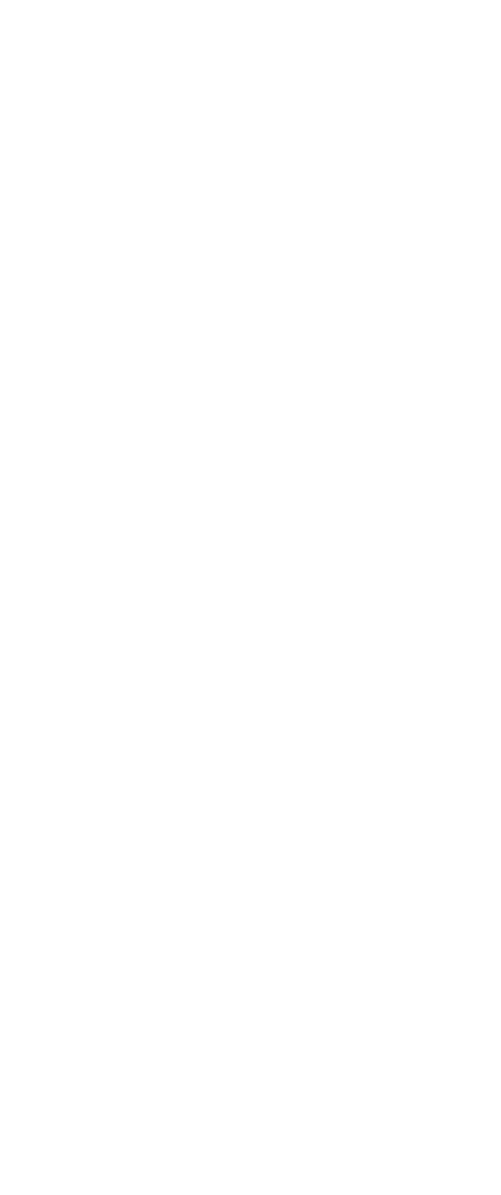


Appendix 6: Species occurring exclusively in non-carbonate sites, from a comparison of samples of equal size $(\underline{n}=73)$ comprised of randomly selected plots.

Herbs

Carex sp.

Castilleja cinerea

Chaenactis stevioides

Chamaesyce polycarpa

Chamaesyce sp.

Chenopodium leptophyllum

Cirsium californicum bernardinum

Collindsia parviflora

Cryptantha holoptera

Cryptantha racemosa

Cuscuta sp.

Datura wrightii

Draba douglasii

Elymus glaucus

Eriastrum sp.

Erigeron aphaenactis

Eriophyllum lanatum

Galium hilendiae

Heuchera parishii

Ivaaxillaris

Juncus balticus

Linanthus killipii

Lomatium nevadense

Lotus strigosus

Malacothamnus orbiculatus

Mellica stricta

Mentzelia albicaulis

Microsteris gracilis

Mimulus androsaceus

Mimulus tilingii

Oryzopsis miliacea

Penstemon labrosus

Phacelia bicoior

Phacelia cicutaria

Phacelia lemmonii

Phlox dolicantha

Plantago sp.

Polypogon monspeliensis

Potentilla glandulosa

Sagina occidentalis

Senecio bernardinus

Sisymbrium altissimum

Sonchus oleraceus

1

1

1

1

1

1

1

2

3

2 
Appendix 6: Species occurring exclusively in non-carbonate sites, from a comparison of samples of equal size $(n=73)$ comprised of randomly selected plots.

Species

Frequency

Herbs

Stipa latiglumis

Thysanocarpus laciniatus

Urtica dioica

Viola douglasii

Viola purpurea

Zauscheneria californica

2

1

1

2

1

1 
Appendix 7: Species whose mean cover or relative abundance was significantly different between carbonate and non-carbonate habitats, as determined by the Kruskal-Wallis ANOVA $(H<6.64 ; \underline{p}<0.01 ; d f=1)$. Mean cover or mean relative abundance (mean), standard deviations $(S D)$, Kruskal-Wallis ANOVA critical values $(H)$ and probability values $(\mathrm{p})$ are shown. The stratification in which the mean value was significantly greater is denoted by $C$ (carbonate stratification) or NC (non-carbonate stratification).

\begin{tabular}{|c|c|c|c|c|c|}
\hline Species & $\mathrm{H}$ & $p<$ & Mean & SD & Strat \\
\hline \multicolumn{6}{|l|}{ Overstory (\% Cover): } \\
\hline $\begin{array}{l}\text { Juniperus osteosperma } \\
\text { Quercus turbinella }\end{array}$ & $\begin{array}{l}36.93 \\
12.06\end{array}$ & $\begin{array}{l}0.00001 \\
0.007\end{array}$ & $\begin{array}{l}5.6 \\
2.8\end{array}$ & $\begin{array}{l}7.8 \\
7.9\end{array}$ & $\underset{N C}{C}$ \\
\hline \multicolumn{6}{|l|}{ Shrubs (\% Cover): } \\
\hline $\begin{array}{l}\text { Cercocarpus ledifolius } \\
\text { Chrysothamnus viscidiflorus }\end{array}$ & 33.47 & 0.00001 & 8.5 & 11.7 & $\mathrm{C}$ \\
\hline stenophyllus & 34.72 & 0.00001 & 3.9 & 4.2 & $\mathrm{C}$ \\
\hline $\begin{array}{l}\text { Ephedra viridis } \\
\text { Eriogonum fasiculatum }\end{array}$ & 13.85 & 0.0002 & 3.0 & 3.0 & $\mathrm{C}$ \\
\hline $\begin{array}{l}\text { polifolium } \\
\text { Eriogonum microthecum }\end{array}$ & 11.59 & 0.0007 & 2.0 & 3.8 & $\mathrm{NC}$ \\
\hline corymbosoides & 32.35 & 0.00001 & 1.1 & 2.3 & C \\
\hline Forsellesia nevadensis & 10.33 & 0.0013 & 1.0 & 3.4 & $\mathrm{C}$ \\
\hline Gutierrezia sarothrae & 9.01 & 0.0027 & 0.6 & 2.3 & NC \\
\hline Haplopappus linearifolius & 22.50 & 0.00001 & 2.2 & 4.3 & NC \\
\hline Leptodactylon pungens & 14.67 & 0.0001 & 0.4 & 1.0 & NC \\
\hline Nolina parryi & 7.05 & 0.008 & 0.2 & 1.1 & NC \\
\hline $\begin{array}{l}\text { Opuntia erinacea } \\
\text { Phoradendron bolleanum }\end{array}$ & 8.28 & 0.004 & 0.2 & 0.6 & NC \\
\hline $\begin{array}{l}\text { densum } \\
\text { Purshia glandulosa } \\
\text { Salvia dorrii }\end{array}$ & $\begin{array}{l}9.31 \\
6.85 \\
10.78\end{array}$ & $\begin{array}{l}0.002 \\
0.009 \\
0.001\end{array}$ & $\begin{array}{l}0.7 \\
3.6 \\
0.8\end{array}$ & $\begin{array}{l}1.3 \\
5.2 \\
4.4\end{array}$ & $\begin{array}{c}\mathrm{C} \\
\mathrm{NC} \\
\mathrm{NC}\end{array}$ \\
\hline \multicolumn{6}{|l|}{ Perennial Bunchgrasses } \\
\hline \multicolumn{6}{|l|}{ (\% Cover) } \\
\hline $\begin{array}{l}\text { Bouteloua gracilis } \\
\text { Oryzopsis hymenoides } \\
\text { Sitanion hystrix }\end{array}$ & $\begin{array}{l}7.05 \\
22.95 \\
48.59\end{array}$ & $\begin{array}{l}0.008 \\
0.00001 \\
0.00001\end{array}$ & $\begin{array}{l}0.8 \\
0.9 \\
1.4\end{array}$ & $\begin{array}{l}4.6 \\
1.3 \\
1.5\end{array}$ & $\begin{array}{r}\mathrm{NC} \\
\mathrm{C} \\
\mathrm{NC}\end{array}$ \\
\hline $\begin{array}{l}\text { Stipa coronata } \\
\text { depauperata }\end{array}$ & 11.66 & 0.0006 & 2.4 & 2.2 & C \\
\hline \multicolumn{6}{|l|}{$\begin{array}{l}\text { Perennial Bunchgrasses } \\
\text { (Rel. Abund.) }\end{array}$} \\
\hline $\begin{array}{l}\text { Oryzopsis hymenoides } \\
\text { Sitanion hystrix } \\
\text { Stipa coronata }\end{array}$ & $\begin{array}{l}36.60 \\
30.67\end{array}$ & $\begin{array}{l}0.00001 \\
0.00001\end{array}$ & $\begin{array}{l}0.9 \\
1.5\end{array}$ & $\begin{array}{l}1.4 \\
1.2\end{array}$ & $\begin{array}{r}\mathrm{C} \\
\mathrm{NC}\end{array}$ \\
\hline depauperata & 11.66 & 0.0006 & 2.2 & 1.3 & $\mathrm{C}$ \\
\hline
\end{tabular}


Appendix 7: Species whose mean cover or relative abundance was significantly different between carbonate and non-carbonate habitats, as determined by the Kruskal-Wallis ANOVA $(\mathrm{H}<6.64 ; \mathrm{p}<0.01, \underline{\mathrm{d} f}=1)$. Mean cover or mean relative abundance (mean), standard deviations $($ SD), Kruskal-Wallis ANOVA critical values $(H)$ and probability values $(p)$ are shown. The stratification in which the mean value was significantly greater is denoted by $\mathrm{C}$ (carbonate stratification) or NC (non-carbonate stratification).

\begin{tabular}{|c|c|c|c|c|c|}
\hline Species & $\mathrm{H}$ & $p<$ & Mean & SD & Strat. \\
\hline \multicolumn{6}{|l|}{ Herbs (Rel. Abund.): } \\
\hline Arceuthobium divaricatum & 10.19 & 0.001 & 0.1 & 0.3 & NC \\
\hline Artemisia ludoviciana & 8.91 & 0.003 & 0.2 & 0.7 & NC \\
\hline Arenaria macradenia & 14.55 & 0.0001 & 0.6 & 1.0 & C \\
\hline Arabis pulchra & 12.26 & 0.0005 & 0.8 & 1.0 & $\mathrm{C}$ \\
\hline Arabis shockleyi & 22.14 & 0.00001 & 0.6 & 1.0 & $\mathrm{c}$ \\
\hline Astragalus albens & 18.79 & 0.00001 & 0.7 & 1.2 & $\mathrm{C}$ \\
\hline Castilleja chromosa & 35.88 & 0.00001 & 0.8 & 1.0 & $\mathrm{C}$ \\
\hline Chaenactis santolinoides & 15.23 & 0.0001 & 0.3 & 0.8 & NC \\
\hline Cryptantha confertiflora & 7.44 & 0.006 & 0.2 & 0.8 & C \\
\hline $\begin{array}{l}\text { Draba cuneifolia } \\
\text { Eriastrum saphirrinum }\end{array}$ & 7.43 & 0.006 & 0.2 & 0.6 & $\mathrm{C}$ \\
\hline saphirrinum & 7.19 & 0.007 & 0.2 & 0.6 & NC \\
\hline Erigeron aphanactis & 12.28 & 0.0005 & 0.2 & 0.8 & NC \\
\hline Erigeron breweri & 8.53 & 0.004 & 0.2 & 0.7 & $\mathrm{C}$ \\
\hline $\begin{array}{l}\text { Eriogonum inflatum } \\
\text { Eriogonum umbellatum }\end{array}$ & 8.00 & 0.004 & 0.4 & 0.8 & NC \\
\hline munzii & 6.93 & 0.009 & 0.2 & 0.6 & NC. \\
\hline \multicolumn{6}{|l|}{ Eriogonum ovalifolium } \\
\hline vineum & 31.69 & 0.00001 & 0.8 & 1.1 & C \\
\hline Eriogonum saxatile & 11.84 & 0.0006 & 0.3 & 0.8 & NC \\
\hline Eriogonum wrightii & 19.57 & 0.00001 & 0.4 & 1.1 & NC \\
\hline Eriophyllum lanatum & 29.74 & 0.00001 & 0.4 & 0.8 & NC \\
\hline Gilia austrooccidentalis & 28.28 & 0.00001 & 1.9 & 1.3 & C \\
\hline Langloisia mathewsii & 8.36 & 0.004 & 0.2 & 0.8 & NC \\
\hline Linanthus breviculus & 14.89 & 0.001 & 0.3 & 0.7 & NC \\
\hline Lotus strigosus & 14.39 & 0.0001 & 0.2 & 0.6 & $\mathrm{NC}$ \\
\hline Machaeranthera canescens & 11.02 & 0.009 & 0.2 & 0.7 & NC \\
\hline Monardella linoides & 6.89 & 0.008 & 0.2 & 0.7 & NC \\
\hline Penstemon eatonii & 11.61 & 0.0007 & 0.4 & 0.7 & C \\
\hline Penstemon labrosus & 8.11 & 0.004 & 0.1 & 0.4 & NC \\
\hline Phacelia douglasii & 10.33 & 0.0013 & 0.3 & 1.9 & C \\
\hline Phacelia fremontii & 12.77 & 0.0004 & 1.2 & 1.4 & $\mathrm{C}$ \\
\hline Phlox austromontaum & 12.25 & 0.0005 & 0.6 & 1.1 & C \\
\hline Senecio bernardinus & 8.11 & 0.004 & 0.1 & 0.4 & NC \\
\hline
\end{tabular}


Appendix 8: Species occurring exclusively in sites occupied by $A$. albens, from a comparison of samples of equal size $(n=30)$ comprised of randomly selected plots.

Species

Frequency

Overstory

Chilopsis linearis

1

Shrubs

Atriplex canescens

Brickellia desertorum

Eriogonum heermannii

Ferocactus acanthodes lecontei

Happlopappus linearifolius

Hymenoclea salsola

Larrea tridentata

Lepidium fremontii

Lycium andersonii

Machaeranthera tortifolia

Rhus trilobata

Yucca shidigera

Yucca whipplei

Perennial Bunchgrasses

Sporobulus cryptandrus

Vulpia octaflora

Herbs

Allium campanularium

Astragalus albens

Cammisonia sp.

Caulanthus cooperi

Chaenactis sp.

Cryptantha angustifolia

Cryptantha muricata

Cryptantha watsonii

Delphinium parishii

Dudleya abramsii

Eriastrum densiflorum

Eriastrum saphirrinum ssp. saphirrinum

Erigeron parishii

Eriogonum davidsonii

Eriogonum maculatum

Eriogonum nidularium

Erioneuron pulchellum

Eriophyllum sp. 
Appendix 8: Species occurring exclusively in sites occupied by $A$. albens, from a comparison of samples of equal size $(n=30)$ comprised of randomly selected plots.

Species

Frequency

Herbs

Eriophyllum wallacei

Eschscholtzia minutiflora

Eucrypta micrantha

Langloisia setosissima

Lepidium lasiocarpum

Linanthus breviculus

Lomatium mojavensis

Mimulus bigelovii

Nemacladus longiflorus

Parishella californica

Phacelia douglasii

Phacelis sp.

Plagiobothrys hispidulus

3

1

3

1

2

1

7

2

3

7

7

1 
Appendix 9: Species whose mean cover or relative abundance was significantly different between sites occupied by $A$. albens and unoccupied carbonate sites, as determined by the Kruskal-Wallis ANOVA $(\mathrm{H}>6.64, \mathrm{p}<0.01, \mathrm{df}=1)$. Mean cover or mean relative abundance (mean), standard deviations $(S D)$, Kruskal-Wallis ANOVA critical values $(H)$ and probability values $(p)$ are shown. The stratification in which the mean value was significantly greater is denoted by AA (sites occupied by $A$. albens) or UC (carbonate sites unoccupied by $A$. albens).

\begin{tabular}{|c|c|c|c|c|c|}
\hline Species & $\mathrm{H}$ & $p<$ & Mean & SD & Strat. \\
\hline \multicolumn{6}{|l|}{ Overstory (\% Cover): } \\
\hline Yucca brevifolia & 13.99 & 0.0002 & 3.0 & 4.5 & AA \\
\hline \multicolumn{6}{|l|}{ Shrubs ( $\%$ Cover): } \\
\hline Cercocarpus ledifolius & 12.37 & 0.0004 & 11.7 & 12.5 & Uc \\
\hline Coleogyne ramossisima & 20.71 & 0.00001 & 14.3 & 12.5 & AA \\
\hline Lepidium fremontii & 12.70 & 0.0004 & 1.0 & 1.5 & AA \\
\hline Opuntia echinocarpa & 6.91 & 0.0086 & 0.5 & 1.0 & AA \\
\hline Purshia glandulosa & 7.45 & 0.0063 & 4.0 & 5.9 & AA \\
\hline Yucca schidigera & 16.87 & 0.00001 & 1.9 & 2.2 & AA \\
\hline \multicolumn{6}{|l|}{ Perennial Bunchgrasses } \\
\hline \multicolumn{6}{|l|}{ (\% Cover) } \\
\hline Aristida fendleriana & 9.71 & 0.0018 & 1.0 & 1.5 & AA \\
\hline Stipa speciosa & 8.24 & 0.0041 & 1.7 & 1.5 & AA \\
\hline \multicolumn{6}{|l|}{ Perennial Bunchgrasses } \\
\hline \multicolumn{6}{|l|}{ (Rel. Abund.) } \\
\hline Aristida fendleriana & 8.74 & 0.0031 & 1.0 & 1.2 & AA \\
\hline Festuca octoflora & 9.42 & 0.0021 & 0.4 & 0.8 & AA \\
\hline Sporobolus cryptandrus & 7.06 & 0.0079 & 0.2 & 0.6 & AA \\
\hline Sitanion hystrix & 13.48 & 0.0002 & 0.8 & 1.0 & uc \\
\hline Stipa speciosa & 12.72 & 0.0004 & 1.7 & 1.4 & $A A$ \\
\hline \multicolumn{6}{|l|}{ Herbs (Rel. Abund.): } \\
\hline Allium sp. & 15.66 & 0.0001 & 0.7 & 1.2 & $A A$ \\
\hline Bromus rubens & 12.79 & 0.0003 & 0.8 & 1.4 & $A A$ \\
\hline Caulanthus cooperi & 8.42 & 0.0037 & 0.4 & 0.9 & $A A$ \\
\hline Cauianthus major & 10.49 & 0.0012 & 0.6 & 0.9 & UC \\
\hline Cryptantha angustifolia & 8.05 & 0.0046 & 0.3 & 0.9 & $A A$ \\
\hline Descurainea pinnata & 7.04 & 0.008 & 1.3 & 1.2 & $A A$ \\
\hline Draba cuneifolia & 9.09 & 0.0026 & 0.5 & 1.0 & $A A$ \\
\hline $\begin{array}{l}\text { Eriastrum densiflorum } \\
\text { Eriastrum saphirrinum }\end{array}$ & 12.91 & 0.003 & 0.6 & 1.3 & AA \\
\hline saphirrinum & 22.49 & 0.0001 & 0.8 & 1.4 & AA \\
\hline Erigeron parishii & 9.84 & 0.0017 & 0.3 & 0.6 & $A A$ \\
\hline Eriogonum inflatum & 10.34 & 0.0013 & 0.2 & 1.2 & AA \\
\hline
\end{tabular}


Appendix 9: Species whose mean cover or relative abundance was significantly different between sites occupied by $A$. albens and unoccupied carbonate sites, as determined by the Kruskal-Wallis ANOVA $(H>6.64, \underline{p}<0.01, \underline{d f}=1)$. Mean cover or mean relative abundance (mean), standard deviations (SD), Kruskal-Wallis ANOVA critical values $(H)$ and probability values $(\mathrm{p})$ are shown. The stratification in which the mean value was significantly greater is denoted by AA (sites occupied by $A$. albens) or UC (carbonate sites unoccupied by $A$. albens).

\begin{tabular}{|c|c|c|c|c|c|}
\hline Species & $\mathrm{H}$ & $\mathrm{p}<$ & Mean & $\mathrm{SD}$ & Strat \\
\hline \multicolumn{6}{|l|}{ Herbs (Rel. Abund.): } \\
\hline Eriogonum maculatum & 10.83 & 0.001 & 0.3 & 0.7 & AA \\
\hline Eriogonum nidularium & 13.67 & 0.0002 & 0.4 & 1.0 & $A A$ \\
\hline Eriophyllum sp. & 8.05 & 0.0046 & 0.2 & 0.5 & $A A$ \\
\hline Lomatium mojavense & 12.42 & 0.0004 & 0.4 & 0.8 & $\mathrm{AA}$ \\
\hline Nama demissum & 12.28 & 0.0005 & 0.6 & 1.2 & AA \\
\hline Nemacladus sp. & 24.14 & 0.00001 & 0.8 & 1.2 & $\mathrm{AA}$ \\
\hline Nemacladus longiflorus & 8.05 & 0.0046 & 0.2 & 0.6 & AA \\
\hline Parishella californica & 19.51 & 0.00001 & 0.5 & 0.9 & $A A$ \\
\hline Phlox austromontanum & 10.34 & 0.0016 & 0.9 & 1.3 & UC \\
\hline Phacelia curvipes & 7.33 & 0.0068 & 0.5 & 1.1 & $A A$ \\
\hline Phacelia douglasii & 22.49 & 0.00001 & 0.8 & 1.4 & AA \\
\hline Phacelia fremontii & 8.51 & 0.0035 & 2.1 & 1.6 & AA \\
\hline Sphaeralcea ambigua & 12.04 & 0.0005 & 0.3 & 0.6 & $A A$ \\
\hline
\end{tabular}


Appendix 10: Species occurring exclusively in sites occupied by E. o. ssp. vineum, from a comparison of samples of equal size (n=28) comprised of randomly selected plots.

Species

Shrubs

Eriogonum heermannii

Forsellesia nevadensis

Glossopetalon spinescens

Hymenoclea salsola

Lepidium fremontii

Lycium andersonii

Yucca whipplei

Herbs

Astragalus coccineus

Cammisonia boothii

Caulanthus cooperi

Cryptantha confertiflora

Cryptantha oxygona

Delphinium parishii

Eriastrum densiflorum

Eriastrum saphirrinum ssp. saphirrinum

Erigeron parishii

Eriogonum ovalifolium ssp. vineum

Eriophyllum sp.

Eriophyllum wallacei

Eucrypta micrantha

Galium hallii

Lewisia rediviva

Lomatium mojavense

Mimulus bigelovii

Phacelia douglasii
Frequency

2

2

2

1

3

1

5

1

1

5

6

1

3

1

1

3

27

1

1

1

1

2 
Appendix 11: Species whose cover or relative abundance was significantly different between E. o. ssp. vineum and unoccupied carbonate habitat, as determined by the Kruskal-Wallis ANOVA ( $\$ 6.64, \mathrm{p}<0.01, \underline{\mathrm{d} f}=1$ ). Mean cover or mean relative abundance (mean), standard deviations (SD), Kruskal-Wallis ANOVA critical values $(H)$ and probability values $(\mathrm{p})$ are shown. The stratification in which the mean value was significantly greater is denoted by EO (sites occupied by E.o. ssp. vineum) or UC (carbonate sites unoccupied by E.o. ssp. vineum).

\begin{tabular}{|c|c|c|c|c|c|}
\hline Species & $\mathrm{H}$ & $p<$ & Mean & $\mathrm{SD}$ & Strat. \\
\hline \multicolumn{6}{|l|}{ Overstory (\% Cover): } \\
\hline $\begin{array}{l}\text { Juniperus osteosperma } \\
\text { Quercus chrysolepis }\end{array}$ & $\begin{array}{l}9.65 \\
7.82\end{array}$ & $\begin{array}{l}0.0019 \\
0.0052\end{array}$ & $\begin{array}{l}4.7 \\
4.2\end{array}$ & $\begin{array}{l}9.4 \\
7.0\end{array}$ & $\begin{array}{l}\text { EO } \\
\text { UC }\end{array}$ \\
\hline \multicolumn{6}{|l|}{ Shrubs (\% Cover): } \\
\hline $\begin{array}{l}\text { Amelanchier utahensis } \\
\text { Ephedra viridis } \\
\text { Yucca schidigera }\end{array}$ & $\begin{array}{r}7.27 \\
12.55 \\
7.04\end{array}$ & $\begin{array}{l}0.007 \\
0.0004 \\
0.009\end{array}$ & $\begin{array}{l}0.7 \\
3.3 \\
0.8\end{array}$ & $\begin{array}{l}1.6 \\
1.2 \\
1.3\end{array}$ & $\begin{array}{l}\text { UC } \\
\text { EO } \\
\text { EO }\end{array}$ \\
\hline \multicolumn{6}{|l|}{$\frac{\text { Perennial Bunchgrasses }}{\text { (\% Cover) }}$} \\
\hline $\begin{array}{l}\text { Poa fendleriana } \\
\text { Sitanion hystrix }\end{array}$ & $\begin{array}{r}8.21 \\
10.99\end{array}$ & $\begin{array}{l}0.0042 \\
0.0009\end{array}$ & $\begin{array}{l}1.1 \\
1.4\end{array}$ & $\begin{array}{l}1.3 \\
1.5\end{array}$ & $\begin{array}{l}\text { UC } \\
\text { UC }\end{array}$ \\
\hline \multicolumn{6}{|l|}{$\frac{\text { Perennial Bunchgrasses }}{\text { (Rel. Abund.) }}$} \\
\hline $\begin{array}{l}\text { Sitanion hystrix } \\
\text { Stipa coronata }\end{array}$ & 23.88 & 0.00001 & 1.1 & 1.1 & UC \\
\hline depauperata & 7.43 & 0.0064 & 2.6 & 1.1 & EO \\
\hline \multicolumn{6}{|l|}{ Herbs (Rel. Abund.): } \\
\hline $\begin{array}{l}\text { Arabis shockleyi } \\
\text { Cryptantha confertiflora } \\
\text { Phacelia douglasii }\end{array}$ & $\begin{array}{r}7.77 \\
8.54 \\
37.76\end{array}$ & $\begin{array}{l}0.0054 \\
0.0035 \\
0.0001\end{array}$ & $\begin{array}{l}0.9 \\
0.5 \\
1.0\end{array}$ & $\begin{array}{l}1.2 \\
1.0 \\
1.3\end{array}$ & $\begin{array}{l}\text { EO } \\
\text { EO } \\
\text { EO }\end{array}$ \\
\hline
\end{tabular}


Appendix 12: Species list for Blackbrush Scrub VT (BBS; $\underline{n}=20)$. Frequencies are shown (Freq.), as well as designations (Desig.), including dominant species (d), species with high constancy (c; $>80 \%$ of occurrences in only one VT), species with high fidelity ( $f$; occurred in $>$ $50 \%$ of plots in this VT), and indicator species (i). Less than 0.1 mean percentage cover or mean relative abundance is indicated by a " $\mathrm{t}$.

Species Mean SD $\quad$ Srea

Overstory (\% Cover):

Chilopsis linearis Juniperus osteosperma

Pinus monophylla

Yucca brevifolia

Shrubs (\% Cover):

Ambrosia dumosa

Arctostaphylos glauca

Artemisia tridentata

Atriplex canescens

Brickellia desertorum

Chrysothamnus nauseosus

Chrysothamnus viscidiflorus stenophyllus

Coleogyne ramosissima

Echinocereus triglochidiatus

Echinocereus engelmannii

Encelia virginensis

Ephedra nevadensis

Ephedra viridis

Eriogonum fasiculatum polifolium

Eriogonum heermannii

Eurotia lanatum

Ferocactus acanthodes lecontei

Forsellesia nevadensis

Grayia spinosa

Gutierrezia microcephala

Gutierrezia sarothrae

Haplopappus linearifolius

Hymenoclea salsola

Larrea tridentata

Lepidium fremontii

Lycium andersonii

Machaeranthera tortifolia

Mirabilis bigelovii

Opuntia basilaris basilaris

Opuntia echinocarpa

Opuntia ramosissima

Prunus fasciculata

Purshia glandulosa

$\begin{array}{ccrc}t & t & 1 & t \\ 0.4 & 1.4 & 4 & \\ 4.3 & 6.0 & 14 & c \\ 2.3 & 4.6 & 14 & c\end{array}$

$\begin{array}{lcrl}0.2 & 0.8 & 1 & f \\ 0.5 & 2.0 & 1 & \\ 0.2 & 0.8 & 1 & \\ 0.2 & 0.8 & 2 & \\ t & t & 1 & \\ 0.6 & 1.3 & 4 & \\ 1.4 & 2.2 & 8 & \\ 27.1 & 14.7 & 21 & \mathrm{c}, \mathrm{d} \\ 0.6 & 1.3 & 4 & \\ 0.4 & 1.1 & 2 & \\ 1.3 & 1.5 & 9 & \\ 3.5 & 4.5 & 14 & \mathrm{c}, \mathrm{i} \\ 1.2 & 2.2 & 10 & \\ 1.6 & 1.5 & 11 & \mathrm{c} \\ 0.2 & 0.8 & 3 & \\ 0.9 & 1.4 & 8 & \\ 0.0 & 0.1 & 1 & f \\ 0.4 & 1.1 & 4 & \\ 1.3 & 4.7 & 2 & \mathrm{f} \\ 5.8 & 10.2 & 15 & \mathrm{c}, \mathrm{d} \\ \mathrm{t} & \mathrm{t} & 1 & \\ 0.4 & 1.1 & 4 & \\ 1.9 & 4.7 & 4 & f \\ \mathrm{t} & \mathrm{t} & 2 & \mathrm{f} \\ 1.4 & 1.5 & 13 & \mathrm{c} \\ 0.6 & 1.3 & 3 & \\ 0.2 & 0.8 & 1 & \mathrm{i} \\ 0.8 & 1.2 & 10 & \\ 0.7 & 1.3 & 7 & \\ 1.1 & 1.5 & 9 & \\ 0.8 & 2.1 & 2 & \mathrm{f} \\ 1.3 & 2.8 & 6 & \\ 0.2 & 0.8 & 3 & \end{array}$


Appendix 12: Species list for Blackbrush Scrub VT (BBS; $\underline{n}=20)$. Frequencies are shown (Freq.), as well as designations (Desig.), including dominant species (d), species with high constancy ( $c ;>80 \%$ of occurrences in only one VT), species with high fidelity ( $f$; occurred in $>$ $50 \%$ of plots in this VT), and indicator species (i). Less than 0.1 mean percentage cover or mean relative abundance is indicated by a " $\mathrm{t}$ ".

\begin{tabular}{lcccc}
\hline Species & Mean & SD & Freq. & Desig. \\
\hline Shrubs (\% Cover): & & & & \\
Rhus trilobata anisophylla & 0.2 & 0.8 & 1 & \\
Salazaria mexicana & 0.6 & 1.3 & 4 & \\
Salvia dorrii & 0.4 & 1.1 & 2 & \\
Salvia mojavensis & 0.4 & 1.1 & 4 & $\mathrm{i}$ \\
Salvia pachyphylla & 0.3 & 0.8 & 2 & \\
Tetradymia axillaris & 2.7 & 10.0 & 1 & $\mathrm{f}$ \\
Totradymia stenolepis & 0.4 & 1.1 & 2 & $\mathrm{f}$ \\
Yucca schidigera & 1.4 & 2.2 & 9 & \\
Yucca whipplei & 0.0 & 0.1 & 2 &
\end{tabular}

Perennial Bunchgrasses

(\% Cov./Rel. Abund.):

Aristida fendleriana

Erioneuron pulchellum

Oryzopsis hymenoides

Poa fendleriana

Sitanion hystrix

Sporobolus cryptandrus

Stipa coronata depauperata

Stipa speciosa

Stipa $\times$ Oryzopsis

$\mathrm{t} / 0.1$

$0.5 / 0.4$

$0.2 / 0.2$

$0.8 / 0.6$

$0.1 / t$

t/0.1

$.4 / 0.4$

$2.2 / 2.2$

$\mathrm{t} / 0.1$

Herbs(Rel. Abund.):

Allium sp.

Amsinckia tessellata

Arabis pulchra

Arabis shockleyi

Arenaria macradenia

Astragalus albens

Astragalus bernardinus

Astragalus coccineus

Astragalus leucolobus

Bromus rubens

Bromus tectorum

Calycoceris parryi

Castilleja chromosa

Caulanthus cooperi

Chamaesyce albomarginata

Chaenactis carfloquinia

Chaenactis sp.

$\begin{array}{llrl}0.9 & 1.3 & 6 & \\ 0.4 & 0.9 & 2 & \mathrm{f} \\ 0.5 & 0.8 & 6 & \\ 0.1 & 0.3 & 3 & \\ 0.4 & 0.9 & 5 & \\ 1.2 & 1.5 & 9 & \\ 0.1 & 0.2 & 1 & \\ 0.1 & 0.5 & 1 & \mathrm{f} \\ 0.2 & 0.6 & 2 & \\ 0.2 & 0.8 & 5 & \\ 3.2 & 0.6 & 20 & \mathrm{c} \\ 0.3 & 0.7 & 5 & \\ 0.4 & 0.5 & 9 & \\ 0.5 & 1.0 & 7 & \\ 0.9 & 1.1 & 7 & \\ \mathrm{t} & \mathrm{t} & 1 & \mathrm{f} \\ \mathrm{t} & \mathrm{t} & 1 & \end{array}$


Appendix 12: Species list for Blackblush Scrub VT (BBS: $\underline{n}=20)$. Frequencies are shown (Freq.), as well as designations (Desig.), including dominant species (d), species with high constancy ( $c ;>80 \%$ of occurrences in only one VT), species with high fidelity ( $f$; occurred in $>$ $50 \%$ of plots in this VT), and indicator species (i). Less than 0.1 mean percentage cover or mean relative abundance is indicated by a "t".

\begin{tabular}{|c|c|c|c|c|}
\hline Species & Mean & SD & Freq. & Desig. \\
\hline \multicolumn{5}{|l|}{ Herbs (Rel. Abundance): } \\
\hline Chaenactis stevioides & 0.1 & 0.3 & 1 & $f$ \\
\hline Chenopodium fremontii & 0.1 & 0.3 & 2 & \\
\hline Cryptantha barbigera & 0.3 & 0.7 & 2 & \\
\hline Cryptantha confertiflora & $t$ & $t$ & 1 & \\
\hline Cryptantha gracilis & 0.3 & 1.1 & $i$ & \\
\hline Cryptantha micrantha & 0.4 & 0.9 & 3 & \\
\hline Cryptantha muricata & 0.4 & 1.1 & 2 & f \\
\hline Cryptantha nevadensis & 1.5 & 1.5 & 12 & $c, d, i$ \\
\hline Cryptantha oxygona & 0.2 & 0.8 & 1 & \\
\hline Cryptantha pterocarya & 1.5 & 1.9 & 6 & \\
\hline Cryptantha sp. & 0.2 & 0.6 & 6 & \\
\hline Cryptantha utahensis & $t$ & $t$ & 1 & \\
\hline Delphinium parryi & 0.2 & 0.6 & 3 & \\
\hline Descurainea pinnata & 1.7 & 1.2 & 14 & c \\
\hline Draba cuneifolia & 0.3 & 0.7 & 2 & \\
\hline Dudleya abramsii & $\mathbf{t}$ & $\mathbf{t}$ & 1 & \\
\hline Eriastrum densiflorum & 0.9 & 1.4 & 9 & \\
\hline Eriastrum saphirrinum saphirrinum & 0.9 & 1.4 & 7 & \\
\hline Erigeron parishii & 0.1 & 0.5 & 3 & \\
\hline Eriogonum davidsonii & $t$ & $\mathbf{t}$ & 1 & \\
\hline Eriogonum inflatum & 0.9 & 1.4 & 9 & $d, i$ \\
\hline Eriogonum maculatum & 0.7 & 1.1 & 6 & t \\
\hline Eriogonum nidularium & $t$ & $\mathbf{t}$ & 4 & i \\
\hline Eriogonum ovalifolium vineum & 0.1 & 0.5 & 1 & \\
\hline Eriogunum saxatile & 0.1 & 0.5 & 1 & \\
\hline Eriophyllum confertiflorum laxiflorum & $\mathbf{t}$ & $t$ & 1 & \\
\hline Eriophyllum sp & 0.2 & 0.6 . & 2 & \\
\hline Eriophyllum wallacei & 0.6 & 0.9 & 5 & f \\
\hline Eschscholzia minutiflora & 0.1 & 0.5 & 1 & \\
\hline Galiurin angustifolium & $t$ & $t$ & 3 & \\
\hline Galium hallii & 0.1 & 0.5 & 1 & f \\
\hline Gilia â.ıs trooccidentalis & 1.6 & 1.4 & 14 & c \\
\hline Hulseá vestita vestita & 0.1 & 0.5 & 1 & \\
\hline Langloisia matthewsii & 0.7 & 1.3 & 4 & \\
\hline Langloisia setosissima & 0.1 & 0.4 & 1 & $\mathfrak{f}$ \\
\hline Lepidium lasiocarpum & 0.1 & 0.7 & 1 & \\
\hline Lepidium nitidum & 0.1 & 0.2 & 1 & $f$ \\
\hline Linanthus bigelovii & 0.1 & 0.4 & $i$ & $\mathrm{f}$ \\
\hline
\end{tabular}


Appendix 12: Species list for Blackbrush Scrub VT (BBS; $\underline{n}=20)$. Frequencies are shown (Freq.), as well as designations (Desig.), including dominant species (d), species with high constancy ( $c ;>80 \%$ of occurrences in only one VT), species with high fidelity (f; occurred in $>$ $50 \%$ of plots in this VT), and indicator species (i). Less than 0.1 mean percentage cover or mean relative abundance is indicated by a " $t$ ".

\begin{tabular}{lcccc}
\hline Species & Mean & SD & Freq. & Desig. \\
\hline Herbs (Rel. Abund.): & & & & \\
\hline Lomatium mohavense & 0.6 & 0.8 & 8 & \\
Malacothrix glabrata & 0.3 & 1.0 & 2 & \\
Mentzelia desertorum & 0.7 & 1.3 & 5 & \\
Mentzelia laevicaulis & 0.2 & 0.7 & 2 & \\
Mentzelia sp. & 0.2 & 0.6 & 2 & \\
Mimulus bigelovii & 0.2 & 0.6 & 3 & \\
Muillamaritima & 0.1 & 0.3 & 2 & \\
Nama demissum & 0.6 & 1.2 & 5 & \\
Nemacladus longiflorus & 0.1 & 0.4 & 1 & \\
Nemacladus sp. & 1.0 & 1.2 & 9 \\
Oenothera californica & 0.1 & 0.5 & 2 & \\
Parishella californica & 0.3 & 0.7 & 3 & \\
Pedicularis semibarbarta & 0.2 & 0.7 & 2 & \\
Penstemon eatonii & 0.1 & 0.2 & 1 & \\
Phacelia campanularia & 0.1 & 0.7 & 1 & \\
Phacelia cryptantha & 0.4 & 0.9 & 4 & \\
Phacelia curvipes & 0.1 & 0.4 & 1 & \\
Phacelia distans & 0.8 & 1.4 & 6 & \\
Phacelia douglasii & 0.3 & 1.1 & 2 & \\
Phacelia fremontii & 1.3 & 1.5 & 11 & c \\
Phacelia sp. & 0.1 & 0.2 & 1 & \\
Pholisma paniculatum & 0.3 & 0.9 & 2 & \\
Plagiobothrys hispidulus & 0.1 & 0.7 & 1 & \\
Salsola kali & 0.9 & 1.2 & 8 & \\
Salvia columbariae & 0.1 & 0.2 & 1 & \\
Sphaeralcea ambigua & 0.6 & 0.9 & 7 & \\
Stephanomeria exigua & 0.2 & 0.8 & 2 & \\
Stephanomeria myrioclada & 0.7 & 0.7 & 12 & c \\
Stephanomeria virgata & 0.3 & 0.8 & 2 & \\
& & & & \\
\hline
\end{tabular}


Appendix 13: Species list for Piñon-Juniper Woodland with Blackbrush Scrub VT (PJW-BBS; $\underline{n}=15$ ). Frequencies are shown (Freq.), as well as designations (Desig.), including dominant species (d), species with high constancy (c; $>80 \%$ of occurrences in only one VT), species with high fidelity ( $f$; occurred in $>50 \%$ of plots in this VT), and indicator species (i). Less than 0.1 mean percentage cover or mean relative abundance is indicated by a " $t$ ".

Species $\quad$ Mean SD $\quad$ Freq

Overstory (\% Cover):

Juniperus osteosperma

Pinus monophylla

Yucca brevifolia

Shrubs (\% Cover):

Arctostaphylos glauca

Artemisia tridentata

Ceanothus greggii vestitus

Cercocarpus ledifolius

Chrysothamnus nauseosus

Chrysothamnus viscidiflorus

Coleogyne ramosissima

Echinocereus englemannii mojavensis

Echinocereus triglochidiatus

Ephedra nevadensis

Ephedra viridis

Eridictyon trichocalyx

Eriogonum fasiculatum polifolium

Eriogonum microthecum corymbosoides

Eurotia lanata

Forsellesia nevadensis

Gutierrezia microcephala

Lepidium fremontii

Lycium andersonii

Machaeranthera tortifolia

Mirabilis bigelovii

Opuntia basilaris basilaris

Opuntia echinocarpa

Phoradendron bolleanum densum

Prunus fasciculata

Purshia glandulosa

Salvia mojavensis

Salvia pachyphylla

Yucca whipplei

$\begin{array}{lrrl}6.6 & 5.9 & 13 & \text { c, d } \\ 11.7 & 6.8 & 14 & \text { c } \\ 1.1 & 1.5 & 7 & \end{array}$

$\begin{array}{llrl}4.1 & 6.8 & 7 & \\ 0.1 & 0.2 & 1 & \\ 1.2 & 2.4 & 5 & \\ 3.8 & 5.3 & 9 & \mathrm{c}, \mathrm{d} \\ 2.2 & 1.0 & 10 & \mathrm{c}, \mathrm{i} \\ 3.8 & 4.7 & 13 & \mathrm{c} \\ 13.1 & 10.6 & 15 & \mathrm{c} \\ 0.1 & 0.2 & 1 & \\ 0.3 & 0.9 & 3 & \\ 0.3 & 0.9 & 1 & \\ 2.7 & 0.9 & 14 & \mathrm{c} \\ 0.6 & 1.2 & 1 & \\ 0.1 & 0.2 & 3 & \\ 0.6 & 1.2 & 3 & \\ \mathrm{t} & \mathrm{t} & 2 & \\ 0.3 & 0.9 & 2 & \\ 0.6 & 1.2 & 3 & \\ 1.1 & 1.5 & 7 & \mathrm{i} \\ 0.3 & 0.9 & 1 & \\ \mathrm{t} & \mathrm{t} & 1 & \\ 0.1 & 0.2 & 1 & \\ 0.4 & 0.9 & 5 & \\ 0.1 & 0.2 & 1 & \\ 0.8 & 1.4 & 4 & \\ 0.8 & 1.4 & 3 & \\ 1.4 & 1.6 & 6 & \\ 0.1 & 0.2 & 1 & \\ 1.4 & 1.5 & 6 & \mathrm{i} \\ 0.9 & 1.4 & 4 & \end{array}$


Appendix 13: Species list for Piñon-Juniper Woodland with Blackbrush Scrub VT (PJW-BBS; $\underline{n}=15$ ). Frequencies are shown (Freq.), as well as designations (Desig.), including dominant species (d), species with high constancy (c; $>80 \%$ of occurrences in only one VT), species with high fidelity ( $f$; occurred in $>50 \%$ of plots in this VT), and indicator species (i). Less than 0.1 mean percentage cover or mean relative abundance is indicated by a "t".

\begin{tabular}{|c|c|c|c|c|}
\hline Species & Mean & $\mathrm{SD}$ & Frea. & Desig. \\
\hline \multicolumn{5}{|l|}{ Perennial Bunchgrasses } \\
\hline \multicolumn{5}{|l|}{ (\% Cov./Rel. Abund.): } \\
\hline Aristida fendleriana & $1.4 / 0.8$ & $1.5 / 1.0$ & 7 & d \\
\hline Oryzopsis hymenoides & $0.6 / 0.7$ & $1.2 / 0.9$ & 1 & \\
\hline Poa fendleriana & $0.7 / 1.0$ & $1.2 / 1.1$ & 8 & c \\
\hline Stipa coronata depauperata & $2.5 / 2.5$ & $1.1 / 1.1$ & 14 & c \\
\hline Stipa speciosa & $0.6 / 0.8$ & $1.2 / 1.3$ & 5 & \\
\hline Stipa x Oryzopysis & $0.1 / 0.1$ & $0.2 / 0.3$ & 1 & \\
\hline \multicolumn{5}{|l|}{ Herbs (Rel. Abund.): } \\
\hline Abronia nana covillei & 0.5 & 1.5 & 2 & \\
\hline Allium sp. & 0.6 & 0.9 & 3 & \\
\hline Arabis pulchra & 1.0 & 1.0 & 7 & \\
\hline Arabis shockleyi & 0.7 & 1.3 & 6 & \\
\hline Arenaria macradenia & 0.7 & 1.1 & 5 & \\
\hline Astragalus albens & 1.3 & 1.3 & 8 & c \\
\hline Astragalus leucolobus & 0.4 & 0.8 & 2 & \\
\hline Brickellia oblongifolia linifolia & 0.6 & 0.8 & 4 & \\
\hline Bromus rubens & 0.6 & 1.2 & 3 & \\
\hline Bromus tectorum & 1.7 & 1.3 & 12 & c \\
\hline Calycoseris parryi & 0.4 & 0.7 & 3 & \\
\hline Camissonia boothii & 0.1 & 0.3 & 1 & $\mathbf{f}$ \\
\hline Castilleja chromosa & 0.8 & 0.9 & 8 & \\
\hline Caulanthus cooperi & 0.2 & 0.4 & 2 & \\
\hline Caulanthus major & 0.4 & 0.8 & 2 & \\
\hline Chaenactis sp. & $t$ & $\mathbf{t}$ & 2 & \\
\hline Chenopodium fremontii & $t$ & $t$ & 1 & \\
\hline Cryptantha angustifolia & 0.4 & 1.2 & 1 & \\
\hline Cryptantha confertiflora & 0.6 & 1.2 & 3 & \\
\hline Cryptantha micrantha & $t$ & $\mathrm{t}$ & 1 & \\
\hline Cryptantha mohavensis & 0.7 & 1.3 & 3 & \\
\hline Cryptantha nevadensis & 0.5 & 0.8 & 4 & \\
\hline Cryptantha pterocarya & 0.2 & 0.6 & 1 & \\
\hline Cryptantha sp. & 0.5 & 1.0 & 4 & \\
\hline Delphinium parishii & 0.8 & 0.4 & 2 & \\
\hline Descurainea pinnata & 1.1 & 1.3 & 6 & \\
\hline Draba corrugata & $t$ & $t$ & 1 & \\
\hline Draba cuneifolia & 0.1 & 0.3 & 3 & \\
\hline Eriastrum densiflorum & 0.4 & 1.2 & 1 & \\
\hline
\end{tabular}


Appendix 13: Species list for Piñon-Juniper Woodland with Blackbrush Scrub VT (PJW-BBS; $\underline{n}=15$ ). Frequencies are shown (Freq.), as well as designations (Desig.), including dominant species (d), species with high constancy (c; $>80 \%$ of occurrences in only one VT), species with high fidelity (f; occurred in $>50 \%$ of plots in this VT), and indicator species (i). Less than 0.1 mean percentage cover or mean relative abundance is indicated by a "t".

\begin{tabular}{|c|c|c|c|c|}
\hline Species & Mean & SD & Freq. & Desig. \\
\hline \multicolumn{5}{|l|}{ Herbs (Rel. Abund.): } \\
\hline Eriastrum diffusum & $\mathbf{t}$ & $t$ & 2 & \\
\hline Eriastrum saphirrinum saphirrinum & 0.6 & 0.9 & 3 & \\
\hline Erigeron parishii & 0.4 & 0.7 & 4 & \\
\hline Eriogonum davidsonii & $t$ & $t$ & 1 & \\
\hline Eriogonum inflatum & 0.4 & 0.7 & 5 & \\
\hline Eriogonum maculatum & 0.1 & 0.3 & 1 & \\
\hline Eriogonum ovalifolium vineum & 1.1 & 1.0 & 9 & $c, d$ \\
\hline Eriogonum saxatile & 0.2 & 0.6 & 1 & \\
\hline Eriophyllum sp. & 0.3 & 0.7 & 2 & \\
\hline Galium angustifolium & 0.1 & 0.3 & 1 & \\
\hline Galium parishii & 0.4 & 0.9 & 2 & \\
\hline Gilia austrooccidentalis & 1.9 & 1.2 & 13 & c \\
\hline Hulsea vestita vestita & 0.3 & 0.7 & 2 & $\mathbf{i}$ \\
\hline Lomatium mojavensis & 0.1 & 0.5 & 1 & \\
\hline Mimulus bigelovii & 0.1 & 0.4 & 2 & \\
\hline Nama demissum & 0.1 & 0.5 & 1 & \\
\hline Nemacladus longiflorus & 0.1 & 0.5 & 1 & \\
\hline Nemacladus sp. & 0.1 & 0.3 & 1 & \\
\hline Oenothera californica & 0.1 & 0.3 & 1 & \\
\hline Oxytheca parishii goodmaniana & 0.1 & 0.4 & 2 & \\
\hline Parishella californica & 0.3 & 0.9 & 2 & \\
\hline Penstemon eatonii & 0.3 & 0.7 & 3 & \\
\hline Phacelia campanularia & 0.2 & 0.6 & 2 & \\
\hline Phacelia cryptantha & 0.3 & 0.7 & 2 & \\
\hline Phacelia curvipes & 0.2 & 0.8 & 1 & \\
\hline Phacelia distans & 0.4 & 0.8 & 3 & \\
\hline Phacelia douglasii & 0.7 & 1.3 & 4 & \\
\hline Phacelia fremontii & 1.3 & 1.5 & 7 & \\
\hline Phacelia parishii & 0.1 & 0.5 & 1 & \\
\hline Salsola kali & 0.5 & 0.8 & 4 & \\
\hline Sphaeralcea ambigua & 0.1 & 0.4 & 2 & \\
\hline Stephanomeria myrioclada & 0.2 & 0.4 & 3 & \\
\hline Stanleya pinnata & 0.1 & 0.5 & 1 & \\
\hline Tricardia watsonii & 0.1 & 0.5 & 1 & $f$ \\
\hline
\end{tabular}


Appendix 14: Species list for Piñon-Juniper Woodland with Flannelbush VT (PJW-F; $\underline{n}=50$ ). Frequencies are shown (Freq.), as well as designations (Desig.), including dominant species (d) species with high constancy ( $c ;>80 \%$ of occurrences in only one VT), species with high fidelity (f; occurred in $>50 \%$ of plots in this VT), and indicator species (i). Less than 0.1 mean percentage cover or mean relative abundance is indicated by a " $t$ ".

Species Mean SD $\quad$ Freg

Overstory (\% Cover):

Juniperus occidentalis

Juniperus osteosperma

Pinus monophylla

Quercus chrysolepis

Quercus turbinella

Yucca brevifolia

Shrubs (\% Cover):

Amelanchier utahensis

Arceuthobium divaricatum

Arctostaphylos glauca

Artemisia tridentata

Atriplex canescens

Ceanothus greggii vestitus

Cercocarpus ledifolius

Chrysothamnus nauseosus

Chrysothamnus viscidiflorus stenophyllus

Coleogyne ramosissima

Echinocereus engelmanniimunzii

Echinocerous triglochidiatus

Encelia virginensis

Ephedra viridis

Eriodictyon trichocalyx

Eriogonum fasiculatum polifolium

Eriogonum microthecum corymbosoides

Foresellesia nevadensis

Fremontodendion californicum

Gutierrezia microcephala

Gutierrezia sarothrae

Haplopappus linearifolius

Mirabilis bigelovii

Opuntia basilaris basilaris

Opuntia echinocarpa

Opuntia littoralis piercii

Phorodendron bolleanum densum

Prunus fasciculata

Purshia glandulosa

Salvia mojavensis

Salvia pachyphylla

Yucca schidigera

$\begin{array}{llrl}0.7 & 3.5 & 1 & \\ 7.2 & 8.7 & 39 & c, d \\ 23.3 & 11.5 & 50 & c \\ 0.1 & 0.6 & 1 & \\ 0.3 & 1.5 & 1 & \\ 2.7 & 3.6 & 39 & c, i\end{array}$

$0.1 \quad 0.6$

$0.1 \quad 0.6$

$1.9 \quad 7.6$

$2.9 \quad 4.9$

$t$

0.8

4.2

0.3

6.0

$t$

0.0

0.6

0.0

4.2

0.1

0.4

1.4

0.3

3.3

1.1

$t$

0.1

0.0

1.4

$\mathrm{t}$

0.0

1.0

2.1

5.7

0.1

0.1

0.7

$\mathrm{t}$

3.5

8.2

0.8

4.8

$\mathrm{t}$

0.1

1.1

0.1

3.3

0.6

1.0

1.5

1.5

8.2

2.2

$t$

0.6

0.1

1.4

$\mathrm{t}$

0.1

c, d

48

3

11

16

6

49

c, d

c

c, i

8

24

1

16

11

3

5

2

34

2

7

1.4

17

5.0

6.5

0.6

0.6

1.3 c

c

c 
Appendix 14: Species list for Piñon-Juniper Woodland with Flannelbush VT (PJW-F; $\underline{n}=50$ ). Frequencies are shown (Freq.), as well as designations (Desig.), including dominant species (d), species with high constancy ( $c$; $>80 \%$ of occurrences in only one VT), species with high fidelity ( $f$; occurred in $>50 \%$ of plots in this VT), and indicator species (i). Less than 0.1 mean percentage cover or mean relative abundance is indicated by a " $\mathrm{t}$.

Species $\quad$ Mean SD Freq. Desig.

\section{Perennial Bunchgrasses}

(\% Cov./Rel. Abund.):

Aristida fendleriana

Bouteloua gracilis

Oryzopsis hymenoides

Poa fendleriana

Poa secunda

Sitanion hystrix

Sporobolus cryptandrus

Stipa coronata depauperata

Stipa speciosa

Stipa $\times$ Oryzopsis

$\begin{array}{ccrc}0.4 / 0.4 & 1.0 / 0.8 & 12 & \\ t / t & t / t & 4 & \\ 1.2 / 1.1 & 1.4 / 1.0 & 32 & c \\ 0.6 / 0.6 & 1.1 / 1.0 & 14 & \\ 0.0 / t & 0.1 / t & t & \\ 0.1 / 0.7 & 0.2 / 1.0 & 21 & \\ t / 0.1 & t / 0.5 & 4 & \\ 3.0 / 2.6 & 3.2 / 1.0 & 47 & c \\ 1.0 / 0.9 & 1.4 / 1.1 & 21 & \\ t / 0.0 & t / 0.1 & 1 & \end{array}$

Herbs (Rel. Abund.):

Abronia nana covillei

Allium campanulatum

Allium sp.

Arabis pulchra

Arabis shockleyi

Arenaria macradenia

Astragalus albens

Astragalus leucolobus

Brickellia oblongifolia linifolia

Bromus rubens

Bromus tectorum

Calochortus kennedyi

Calycoseris parryi

Castilleja chromosa

Castilleja linearifolia

Caulanthus cooperi

Caulanthus major

Chamaesyce albomarginata

Chaenactic glabriuscula

Cordylanthus nevinii

Cryptantha angustifolia

Cryptantha confertiflora

Cryptantha gracilis

Cryptantha micrantha

Cryptantha mohavensis

Cryptantha nevadensis

Cryptantha oxygona

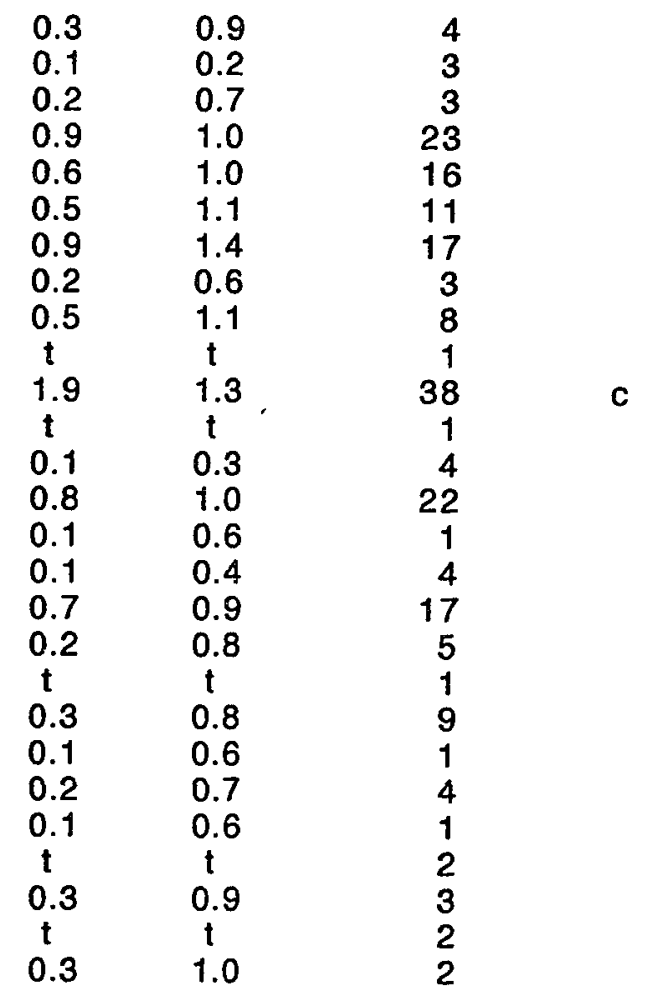


Appendix 14: Species list for Piñon-Juniper Woodland with Flannelbush VT (PJW-F; $\underline{n}=50$ ). Frequencies are shown (Freq.), as well as designations (Desig.), including dominant species (d), species with high constancy ( $c ;>80 \%$ of occurrences in only one VT), species with high fidelity ( $f$; occurred in $>50 \%$ of plots in this VT), and indicator species (i). Less than 0.1 mean percentage cover or mean relative abundance is indicated by a " $t$ ".

\begin{tabular}{|c|c|c|c|c|}
\hline Species & Mean & SD & Freq. & Desig. \\
\hline \multicolumn{5}{|l|}{ Herbs (Rel. Abund.): } \\
\hline Cryptantha pterocarya & 0.0 & 0.2 & 1 & \\
\hline Cryptantha sp. & 0.4 & 0.7 & 10 & \\
\hline Cryptantha utahensis & $t$ & $t$ & 1 & \\
\hline Cryptantha watsonii & 0.2 & 0.6 & 2 & $f$ \\
\hline Descurainea pinnata & 1.0 & 1.1 & 27 & \\
\hline Draba corrugata & $t$ & $t$ & 4 & \\
\hline Draba cuneifolia & 0.0 & 0.2 & 7 & \\
\hline Dudleya abrarnsii & $\mathrm{t}$ & $t$ & 1 & \\
\hline Eriastrum saphirrinum saphirrinum & $\mathfrak{t}$ & $\mathbf{t}$ & 1 & \\
\hline Erigeron parishii & 0.1 & 0.4 & 1 & \\
\hline Eriogonum davidsonii & $\mathrm{t}$ & $t$ & $i$ & \\
\hline Eriogonum nidularium & 0.1 & 0.6 & 1 & \\
\hline Eriogonum ovalifolium vineum & 1.5 & 1.3 & 19 & \\
\hline Eriogonum saxatile & 0.2 & 0.6 & 3 & \\
\hline Eriogonum umbellatum rinunzii & $t$ & t & 1 & \\
\hline Eriophyylum lanatum & 0.0 & 0.2 & $i$ & \\
\hline Festuca megalura & $t$ & $\mathrm{t}$ & 1 & \\
\hline Galium angustifolium & 0.3 & 0.7 & 8 & \\
\hline Galium parishii & 0.1 & 0.3 & 2 & \\
\hline Gilia austracocidentalis & 2.0 & 1.5 & 40 & c \\
\hline Hulsea vestita vestita & 0.1 & 0.4 & 1 & \\
\hline Lepidium lasiocarpum & 0.0 & 0.3 & 1 & \\
\hline Lepidium perfoliatum & 0.1 & 0.3 & 2 & $f$ \\
\hline Lomalium mohavense & 0.1 & 0.4 & 1 & \\
\hline Mentzelia desertorum & 0.0 & 0.3 & 1 & \\
\hline Mentzelia sp. & 0.2 & 0.5 & 5 & \\
\hline Muillamaritima & 0.1 & 0.3 & 4 & \\
\hline Nama demissum & 0.1 & 0.4 & 2 & \\
\hline Nemacladus sp. & 0.3 & 0.7 & 8 & \\
\hline Oxytheca parishii goodmaniana & 0.0 & 0.3 & 9 & f \\
\hline Parishella californica & 0.1 & 0.4 & 2 & \\
\hline Penstemon eatonii & 0.4 & 0.7 & 15 & i \\
\hline Phacelia cryptantha & 0.1 & 0.3 & 2 & \\
\hline Phacelia curvipes & 0.3 & 0.9 & 6 & \\
\hline Phacelia douglasii & 0.4 & 1.1 & 8 & \\
\hline Phacelia fremontii & 1.8 & 1.4 & 34 & c \\
\hline Phacelia sp. & 0.0 & 0.3 & 1 & \\
\hline Phlox austromontanum & 0.7 & 1.2 & 15 & $i$ \\
\hline Salsola kali & 0.1 & 0.4 & 4 & \\
\hline Sonchus oleraceus & 0.0 & 0.1 & 1 & $\mathrm{f}$ \\
\hline Sphaeralcea ambigua & 0.1 & 0.2 & 3 & \\
\hline
\end{tabular}


Appendix 14: Species list for Piñon-Juniper Woodland with Flannelbush VT (PJW-F; $\underline{n}=50$ ). Frequencies are shown (Freq.), as well as designations (Desig.), including dominant species (d), species with high constancy ( $c_{;}>80 \%$ of occurrences in only one VT), species with high fidelity (f; occurred in $>50 \%$ of plots in this VT), and indicator species (i). Less than 0.1 mean percentage cover or mean relative abundance is indicated by a "t".

Species

Herbs (Rel. Abund.)

Stephanomeria myrioclada

Stephanomeria virgata
Mean

SD

0.0

0.0

0.2

0.1

Freq.

Desig.

\section{.2}

1 
Appendix 15: Species list for Piñon-Juniper Woodland with Manzanita VT (PJW-M; $\underline{n}=47$ ). Frequencies are shown (Freq.), as well as designations (Desig.), including dominant species (d), species with high constancy ( $c$; $>80 \%$ of occurrences in only one VT), species with high fidelity (f; occurred in $>50 \%$ of plots in this VT), and indicator species (i). Less than 0.1 mean percentage cover or mean relative abundance is indicated by a "t".

\begin{tabular}{|c|c|c|c|c|}
\hline Species & Mean & SD & Freq. & Desig. \\
\hline \multicolumn{5}{|l|}{ Overstory (\% Cover): } \\
\hline Juniperus occidentalis & 0.7 & 3.3 & 2 & \\
\hline Juniperus osteosperma & 5.8 & 5.3 & 36 & $c, d$ \\
\hline Pinus monophylla & 15.1 & 9.8 & 46 & $\mathrm{c}$ \\
\hline Quercus chrysolepis & 1.7 & 4.7 & 8 & \\
\hline Yucca brevifolia & 0.6 & 1.7 & 10 & \\
\hline \multicolumn{5}{|l|}{ Shrubs (\% Cover): } \\
\hline Amelanchier utahensis & 0.5 & 1.6 & 4 & $\mathrm{i}$ \\
\hline Arctostaphylos glauca & 4.9 & 7.6 & 14 & d \\
\hline Artemisia tridentata & 0.3 & 1.0 & 4 & \\
\hline Brickellia desertorum & $t$ & $t$ & 1 & \\
\hline Ceanothus greggii vestitus & 2.4 & 7.7 & 10 & \\
\hline Cercocarpus ledifolius & 17.8 & 12.3 & 43 & $c, d$ \\
\hline Chrysothamnus nauseosus & 1.1 & 1.5 & 15 & \\
\hline Chrysothamnus viscidiflorus stenophyllus & 4.0 & 3.6 & 39 & c \\
\hline Coleogyne ramosissima & 0.2 & 0.8 & 4 & \\
\hline Echinocereus engelmannii & $t$ & $t$ & 6 & \\
\hline Echinocereus triglochidiatus mojavensis & 0.2 & 0.6 & 13 & \\
\hline Ephedra nevadensis & 0.1 & 0.6 & 3 & \\
\hline Ephedra viridis & 3.1 & 3.2 & 41 & c \\
\hline Eriodictyon trichocalyx & 0.1 & 0.6 & 2 & \\
\hline Eriogonum fasiculatum polifolium & 0.1 & 0.6 & 3 & \\
\hline Eriogonum heermannii & $t$ & $t$ & 1 & \\
\hline Eriogonum microthecum corymbosoides & 1.6 & 3.4 & 20 & \\
\hline Forsellesia nevadensis & 2.2 & 5.5 & 11 & \\
\hline Gutierrezia microcephala & 0.5 & 1.2 & 12 & \\
\hline Gutierrezia sarothrae & 0.3 & 1.4 & 2 & \\
\hline Haplopappus linearifolius & 0.2 & 0.8 & 2 & \\
\hline Hymenoclea salsola & 0.1 & 0.6 & 1 & \\
\hline Mirabilis bigelovii & 0.1 & 0.6 & 1 & \\
\hline Opuntia basilaris basilaris & 0.2 & 0.8 & 7 & \\
\hline Opuntia echinocarpa & $\mathbf{t}$ & $\mathrm{t}$ & 1 & \\
\hline Opuntia littoralis piercii & 0.2 & 0.8 & 4 & \\
\hline Phorodendron bolleanum densum & 0.8 & 1.3 & 10 & \\
\hline Prunus fasciculata & 0.1 & 0.6 & 4 & \\
\hline Purshia glandulosa & 0.0 & 0.1 & 4 & \\
\hline Salazaria mexicana & $t$ & $t$ & 3 & \\
\hline Salvia pachyphylla & 1.8 & 2.4 & 23 & \\
\hline Tetradymia canescens & 0.1 & 0.6 & 2 & \\
\hline Yucca schidigera & 0.0 & 0.1 & 11 & \\
\hline Yucca whipplei & 0.1 & 0.6 & 3 & \\
\hline
\end{tabular}


Appendix 15: Species list for Piñon-Juniper Woodland with Manzanita VT (PJW-M; $\underline{n}=47$ ). Frequencies are shown (Freq.), as well as designations (Desig.), including dominant species (d), species with high constancy ( $c ;>80 \%$ of occurrences in only one VT), species with high fidelity (f; occurred in $>50 \%$ of plots in this VT), and indicator species (i). Less than 0.1 mean percentage cover or mean relative abundance is indicated by a "t".

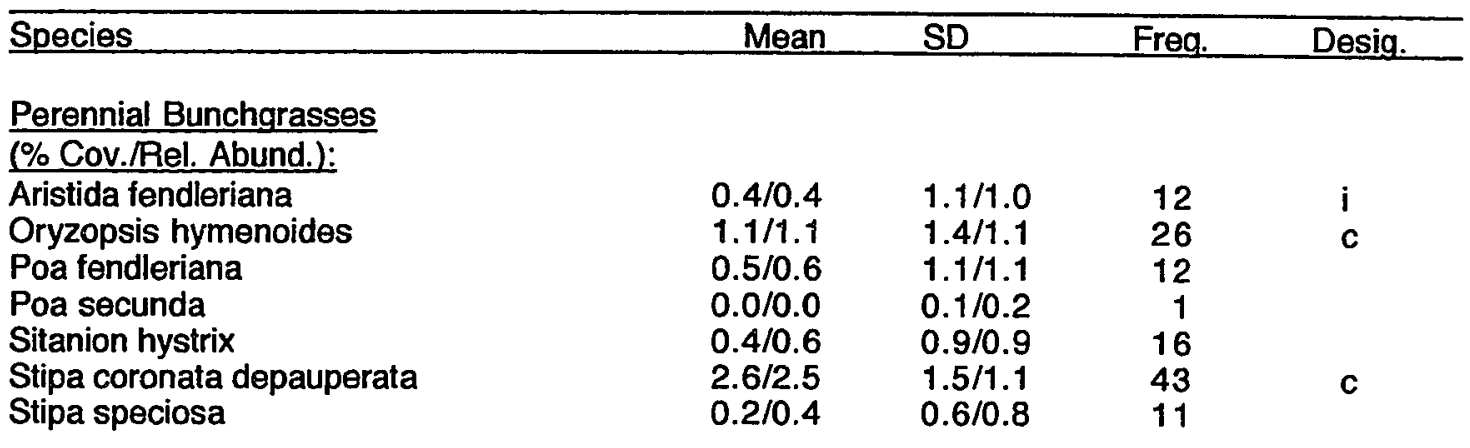

Herbs (Rel. Abund.):

Abronia nana covillei

Allium sp.

Arabis pulchra

Arabis shockleyi

Arenaria macradenia

Artemisia ludoviciana

Astragalus albens

Astragalus bernardinus

Astragalus leucolobus

Brickellia oblongifolia linifolia

Bromus rubens

Bromus tectorurn

Calycoseris parryi

Castilleja chromosa

Caulanthus cooperi

Caulanthus major

Cordylanthus nevinii

Cryptantha barbigera

Cryptantha confertiflora

Cryptantha mohavense

Cryptantha nevadensis

Cryptantha oxygona

Cryptantha pterocarya

Cryptantha sp.

Delphinium parishii

Descurainea pinnata

Draba corrugata

Draba cuneifolia

Eriastrum diffusum

Erigeron parishii

$\begin{array}{ccr}0.1 & 0.5 & 6 \\ 0.1 & 0.5 & 2 \\ 0.8 & 1.1 & 17 \\ 0.7 & 1.0 & 22 \\ 0.7 & 1.2 & 14 \\ 0.0 & 0.3 & 1 \\ 0.0 & 0.2 & 1 \\ 0.1 & 0.3 & 2 \\ 0.1 & 0.4 & 2 \\ 0.4 & 0.7 & 12 \\ 0.1 & 0.4 & 1 \\ 1.0 & 1.4 & 20 \\ 0.0 & 0.2 & 1 \\ 1.2 & 1.1 & 24 \\ \mathrm{t} & \mathrm{t} & 2 \\ 0.8 & 1.0 & 13 \\ 0.4 & 1.0 & 6 \\ 0.0 & 0.2 & 1 \\ 0.6 & 1.2 & 6 \\ 0.2 & 0.7 & 3 \\ 0.1 & 0.6 & 5 \\ \mathrm{t} & \mathrm{t} & 3 \\ 0.1 & 0.4 & 1 \\ \mathrm{t} & \mathrm{t} & 6 \\ 0.1 & 0.6 & 3 \\ 0.1 & 0.3 & 6 \\ \mathrm{t} & \mathrm{t} & 2 \\ \mathrm{t} & \mathrm{t} & 1 \\ \mathrm{t} & \mathrm{t} & 2 \\ 0.0 & 0.2 & 2 \\ & & \end{array}$


Appendix 15: Species list for Piñon-Juniper Woodland with Manzanita VT (PJW-M; $\underline{n}=47$ ). Frequencies are shown (Freq.), as well as designations (Desig.), including dominant species (d), species with high constancy ( $c ;>80 \%$ of occurrences in only one VT), species with high fidelity ( $f$; occurred in $>50 \%$ of plots in this VT), and indicator species (i). Less than 0.1 mean percentage cover or mean relative abundance is indicated by a " 4 ".

\begin{tabular}{|c|c|c|c|c|}
\hline Species & Mean & SD & Freq. & Desig. \\
\hline \multicolumn{5}{|l|}{ Herbs (Rel. Abund.): } \\
\hline Eriogonum inflatum & $t$ & $t$ & 1 & \\
\hline Eriogonum ovalifolium vineum & 1.2 & 1.3 & 20 & \\
\hline Eriophyllum wallacei & 0.0 & 0.2 & 1 & \\
\hline Erysimum capitatum & 0.1 & 0.3 & 3 & \\
\hline Eschscholtzia minutiflora & 0.0 & 0.2 & 1 & \\
\hline Festuca megalura & $t$ & $t$ & $i$ & \\
\hline Festuca octoflora & 0.1 & 0.4 & 1 & \\
\hline Galium angustifolium & 0.1 & 0.5 & 7 & \\
\hline Galium parishii & 0.1 & 0.4 & 2 & \\
\hline Gilia austrooccidentalis & 1.4 & 1.3 & 32 & c \\
\hline Gilia sp. & $t$ & $t$ & 1 & \\
\hline Hulsea vestita vestita & 0.4 & 0.8 & 5 & \\
\hline Lepidium lasiocarpum & 0.0 & 0.2 & 1 & \\
\hline Lewisia rediviva & 0.1 & 0.3 & 2 & $f$ \\
\hline Linanthus lewisii & 0.1 & 0.4 & 1 & $f$ \\
\hline Lomatium mojavense & 0.0 & 0.3 & 1 & \\
\hline Machaeranthera canescens & 0.0 & 0.2 & 1 & \\
\hline Malacothrix glabrata & 0.0 & 0.2 & 2 & \\
\hline Mentzelia montana & 0.0 & 0.3 & 1 & \\
\hline Nama demissum & 0.0 & 0.3 & 1 & \\
\hline Oxytheca parishii goodmaniana & 0.5 & 1.0 & 9 & 1 \\
\hline Parisheila californica & 0.1 & 0.4 & 1 & \\
\hline Penstemon eatonii & 0.5 & 0.8 & 14 & \\
\hline Phacelia campanularia & 0.1 & 0.4 & 1 & \\
\hline Phacelia cryptantha & 0.0 & 0.3 & 1 & \\
\hline Phacelia douglasii & 0.1 & 0.5 & 2 & \\
\hline Phacelia fremontii & 0.9 & 1.3 & 19 & \\
\hline Phacelia parishii & 0.0 & 0.2 & 1 & \\
\hline Phacelia sp. & 0.0 & 0.2 & 1 & \\
\hline Phlox austromontanum & 0.7 & 1.2 & 12 & \\
\hline Phlox diffusa & 0.1 & 0.4 & 1 & $f$ \\
\hline Salsola kali & 0.1 & 0.5 & 4 & \\
\hline Silene verecunda & 0.0 & 0.3 & 1 & \\
\hline Stanleya pinnata & 0.1 & 0.5 & 3 & \\
\hline Stephanomeria myrioclada & 0.0 & 0.2 & 2 & \\
\hline
\end{tabular}


Appendix 16: Species list for Blackbrush Scrub-Piñon Woodland transition VT (BBS-PW; $\mathrm{n}=8$ ). Frequencies are shown (Freq.), as well as designations (Desig.), including dominant species (d), species with high constancy ( $c ;>80 \%$ of occurrences in only one VT), species with high fidelity (f; occurred in $>50 \%$ of plots in this VT), and indicator species (i). Less than 0.1 mean percentage cover or mean relative abundance is indicated by a " $t$ ".

\begin{tabular}{lllll}
\hline Species & Mean & SD & Freq. & Desig.
\end{tabular}

Overstory (\% Cover):

Juniperus osteosperma

Pinus monophylla

Quercus chrysolepis

Yucca brevifolia

$\begin{array}{llll}2.2 & 6.2 & 1 & \\ 8.6 & 7.6 & 7 & \\ 0.1 & 0.2 & 1 & \\ 4.8 & 5.6 & 7 & \text { c, d }\end{array}$

Shrubs (\% Cover):

Amsonia brevifolia

Artemisia tridentata

Chrysothamnus viscidiflorus stenophylius

Coleogyne ramosissima

Echinocereus triglochidiatus mojavensis

Encelia virginensis

Ephedra californica

Ephedra nevadensis

Ephedra viridis

Eriogonum fasiculatum polifolium

Eurotia lanatum

Fremontodendron californicum

Gutierrezia microcephala

Haplopappus cuneatus

Haplopappus linearifolius

Mirabilus bigelovii

Opuntia basilaris basilaris

Prunus fasciculata

Purshia glandulosa

Rhamnus ilicifolia

Salvia dorii

Yucca schidigera

Yucca whipplei

$\begin{array}{llll}0.4 & 1.1 & 1 & \text { f } \\ 2.9 & 6.0 & 3 & \mathrm{i} \\ 0.4 & 1.1 & 1 & \\ 9.4 & 13.7 & 4 & \mathrm{~d} \\ 2.6 & 6.1 & 2 & \\ 0.4 & 1.1 & 1 & \\ 0.4 & 1.1 & 1 & 1 \\ 0.8 & 1.4 & 2 & \\ 4.3 & 2.8 & 7 & \mathrm{c} \\ 7.4 & 6.7 & 7 & \mathrm{c}, \mathrm{d} \\ 0.4 & 1.1 & 1 & \\ 0.4 & 1.1 & 1 & \\ 1.1 & 1.6 & 3 & \\ 0.9 & 2.7 & 1 & \\ 8.1 & 7.9 & 7 & \mathrm{c} \\ 0.4 & 1.1 & 1 & \\ 0.9 & 1.3 & 5 & \mathrm{c} \\ 1.7 & 2.7 & 3 & \\ 9.0 & 7.2 & 8 & \mathrm{c}, \mathrm{d} \\ 0.4 & 1.1 & 1 & \\ 5.5 & 13.0 & 4 & \mathrm{c} \\ 2.4 & 2.5 & 5 & \mathrm{c} \\ 0.4 & 1.1 & 1 & \end{array}$

Perennial Bunchgrasses

(\% Cov./Rel. Abund.):

Aristida fendleriana

$0.4 / 0.3$

Poa fendleriana

Poa secunda

$1.1 / 1.0$

1.1/0.7 1

Sitanion hystrix

$0.8 / 0.4$

$0.8 / 1.4$

$1.4 / 1.1$

Stipa coronata depauperata

$1.8 / 1.1$

$2.6 / 1.1$

$1.1 / 1.1$

$1.6 / 1.6$

Stipa speciosa

$6.3 / 2.5$

$7.0 / 1.3$

c 
Appendix 16: Species list for Blackbrush Scrub-Piñon Woodland transition VT (BBS-PW; $\underline{n}=8$ ). Frequencies are shown (Freq.), as well as designations (Desig.), including dominant species (d), species with high constancy ( $c ;>80 \%$ of occurrences in only one VT), species with high fidelity (f; occurred in $>50 \%$ of plots in this VT), and indicator species (i). Less than 0.1 mean percentage cover or mean relative abundance is indicated by a "t".

Species Mean SD Freg. Desig.

Herbs (Rel. Abund.):

\begin{tabular}{|c|c|c|c|}
\hline Antennaria rosea & 0.1 & 0.4 & 1 \\
\hline Arceuthobium divaricatum & 0.4 & 0.7 & 2 \\
\hline Arenaria ri:acradenia & 0.6 & 1.2 & 2 \\
\hline Arabis pulchra & 0.3 & 0.5 & 2 \\
\hline Arabis shockleyi & 0.1 & 0.4 & 1 \\
\hline Astragalus albens & 0.3 & 0.7 & 1 \\
\hline Brickéllia oblongifolia linifolia & 0.6 & 1.9 & 2 \\
\hline Bromus rubens & 0.6 & 1.9 & 2 \\
\hline Bromus tectorum & 3.5 & 0.5 & 8 \\
\hline Castilleja chromosa & 0.3 & 0.5 & 2 \\
\hline Caulanthus cooperi & 0.4 & 0.7 & 2 \\
\hline Calochortus kennedyi & 0.1 & 0.4 & 1 \\
\hline Chamaesyce albomarginata & 1.0 & 1.4 & 3 \\
\hline Chaenactis sp & 0.1 & 0.4 & 1 \\
\hline Chamaesyce polycarpa & 0.4 & 1.1 & 1 \\
\hline Cirsium californicum & 0.1 & 0.4 & 1 \\
\hline Cordylanthus nevadensis & 0.3 & 0.7 & 1 \\
\hline Cryptantha barbigera & 0.4 & 1.1 & 1 \\
\hline Cryptantha circumscissa & 0.3 & 0.7 & 1 \\
\hline Cryptantha pterocarya & 1.4 & 1.5 & 4 \\
\hline Cryptantha utahensis & 0.3 & 0.7 & 1 \\
\hline Cryptantha sp. & 0.4 & 1.1 & 1 \\
\hline Descurainia pinnata & 2.1 & 1.4 & 6 \\
\hline Draba cuneifolia & 0.1 & 0.4 & 1 \\
\hline Dudleya abramsii & 0.1 & 0.4 & 1 \\
\hline Eriogonum davidsonii & 0.5 & 0.9 & 2 \\
\hline Eriastrum densiflorum & 0.4 & 1.1 & 1 \\
\hline Eriophyllum lanatum & 0.6 & 1.2 & 2 \\
\hline Erigeron parishii & 0.1 & 0.4 & 1 \\
\hline Eriogonum saxatile & 0.4 & 1.1 & 1 \\
\hline Eriastrum saphirrinum saphirrinum & 0.9 & 1.6 & 2 \\
\hline Eriogonum wrightii & 0.4 & 1.1 & 1 \\
\hline Galium angustifolium & 0.3 & 0.7 & 1 \\
\hline Gilia austrooccidentalis & 2.3 & 1.4 & 7 \\
\hline Langloisia mathewsii & 0.6 & 1.2 & 2 \\
\hline Linanthus breviculus & 0.8 & 1.4 & 2 \\
\hline Machaeranthera canescens & 0.5 & 1.1 & 2 \\
\hline Malocothrix glauca & 0.4 & 0.7 & 2 \\
\hline Mentzelia desertorum & 0.1 & 0.4 & 1 \\
\hline
\end{tabular}


Appendix 16: Species list for Blackbrush Scrub-Piñon Woodland transition VT (BBS-PW; $\underline{n}=8$ ). Frequencies are shown (Freq.), as well as designations (Desig.), including dominant species (d), species with high constancy (c; $>80 \%$ of occurrences in only one VT), species with high fidelity ( $f$; occurred in $>50 \%$ of plots in this VT), and indicator species (i). Less than 0.1 mean percentage cover or mean relative abundance is indicated by a "t".

\begin{tabular}{|c|c|c|c|c|}
\hline Species & Mean & SD & Freq. & Desig. \\
\hline \multicolumn{5}{|l|}{ Herbs (Rel. Abund.): } \\
\hline Mentzelia sp. & 0.3 & 0.7 & 1 & \multirow{9}{*}{$c, d, i$} \\
\hline Muillamanitima & 0.1 & 0.4 & 1 & \\
\hline Phacelia distans & 1.1 & 1.4 & 4 & \\
\hline Phacelia douglasii & 0.3 & 0.7 & 1 & \\
\hline Phacelia fremontii & 0.6 & 1.2 & 2 & \\
\hline Salvia columbariae & 0.3 & 0.7 & 1 & \\
\hline Sphaeralcea ambigua & 0.8 & 1.4 & 2 & \\
\hline Stephanomeria myrioclada & 0.6 & 0.9 & 3 & \\
\hline Stephanomeria virgata & 0.4 & 0.7 & 2 & \\
\hline
\end{tabular}


Appendix 17: Species list for Piñon-Juniper Woodland with Yucca VT (PJW-Y; $\underline{n}=15)$. Frequencies are shown (Freq.), as well as designations (Desig.), including dominant species (d), species with high constancy ( $c$; $>80 \%$ of occurrences in only one VT), species with high fidelity ( $f$; occurred in $>50 \%$ of plots in this VT), and indicator species (i). Less than 0.1 mean percentage cover or mean relative abundance is indicated by a " $t$ ".

\begin{tabular}{|c|c|c|c|c|}
\hline Species & Mean & SD & Freq. & Desig. \\
\hline \multicolumn{5}{|l|}{ Overstory (\% Cover): } \\
\hline Juniperus californica & 0.5 & 1.2 & 1 & \\
\hline Juniperus osteosperma & 6.3 & 15.3 & 2 & d \\
\hline Pinus monophylla & 14.2 & 5.2 & 8 & c \\
\hline Quercus chrysolepis & 3.0 & 3.7 & 5 & $c, i$ \\
\hline Yucca brevifolia & 0.6 & 1.2 & 3 & \\
\hline \multicolumn{5}{|l|}{ Shrubs (\% Cover): } \\
\hline Arceuthobium divaricatum & 0.5 & 1.2 & 1 & \\
\hline Arctostaphylos glauca & 17.2 & 26.7 & 5 & C \\
\hline Brickellia arguta & 0.5 & 1.2 & 1 & $\mathbf{i}$ \\
\hline Brickellia califomica & 0.5 & 1.2 & 1 & \\
\hline Ceanothus greggii vestitus & 6.8 & 15.1 & 2 & d \\
\hline Cercocarpus ledifolius & 2.9 & 7.1 & 1 & \\
\hline Chrysothamnus nauseosus & 1.8 & 3.1 & 2 & \\
\hline Chrysothamnus viscidiflorus & 2.8 & 2.8 & 5 & $c$ \\
\hline Coleogyne ramosissima & $t$ & $t$ & 1 & \\
\hline Echinocerus triglochidiatus mojavensis & 1.0 & 1.6 & 3 & \\
\hline Encelia virginensis & 0.6 & 1.2 & 2 & \\
\hline Ephedra viridis & 2.1 & 1.4 & 6 & c \\
\hline Eriogonum fasiculatum polifolium & 2.0 & 1.6 & 6 & c \\
\hline Gutierrezia microcephala & 1.8 & 3.1 & 3 & \\
\hline Haplopappus cuneatus & 0.5 & 1.2 & 1 & \\
\hline Haplopappus linearifolius & 1.8 & 3.1 & 3 & \\
\hline Opuntia basilaris basilaris & 1.0 & 1.6 & 2 & \\
\hline Opuntia erinacea & 0.6 & 1.2 & 2 & \\
\hline Opuntia littoralis piercii & 0.5 & 1.2 & 2 & \\
\hline Phorodendron bolleanum densum & 0.5 & 1.2 & 2 & \\
\hline Prunus fasciculata & 1.0 & 1.6 & 2 & \\
\hline Purshia glandulosa & 4.9 & 6.3 & 7 & $c, d$ \\
\hline Rhamnus ilicifolia & 0.5 & 1.2 & 1 & \\
\hline Yucca schidigera & 1.0 & 1.5 & 4 & c \\
\hline Yucca whipplei & 0.5 & 1.2 & 3 & \\
\hline \multicolumn{5}{|l|}{ Perennial Bunchgrasses } \\
\hline \multicolumn{5}{|l|}{ (\% Cov./Rol. Abund.): } \\
\hline Aristida fendleriana & $0.6 / 0.4$ & $1.2 / 0.9$ & 3 & \\
\hline Oryzopsis hymenoides & $1.1 / 0.4$ & $1.5 / 0.7$ & 2 & \\
\hline Poa fendleriana & $1.0 / 0.6$ & $1.6 / 1.2$ & 2 & \\
\hline Sitanion hystrix & $0.3 / 0.8$ & $0.3 / 0.9$ & 4 & c \\
\hline Stipa coronata depauperata & $2.6 / 2.6$ & $1.0 / 0.9$ & 8 & c \\
\hline Stipa speciosa & 2.5/2.4 & $1.2 / 1.0$ & 7 & c \\
\hline
\end{tabular}


Appendix 17: Species list for Piñon-Juniper Woodland with Yucca VT (PJW-Y; $\underline{n}=15$ ). Frequencies are shown (Freq.), as well as designations (Desig.), including dominant species (d), species with high constancy ( $c ;>80 \%$ of occurrences in only one VT), species with high fidelity ( $f$; occurred in $>50 \%$ of plots in this VT), and indicator species (i). Less than 0.1 mean percentage cover or mean relative abundance is indicated by a " $t$ ".

\begin{tabular}{|c|c|c|c|c|}
\hline Species & Mean & SD & Freg. & Desig. \\
\hline \multicolumn{5}{|l|}{ Herbs (Rel. Abund.): } \\
\hline Allium sp. & 0.3 & 0.8 & 1 & \\
\hline Arabis pulchra & 0.7 & 1.0 & 2 & \\
\hline Arabis shockloyi & 0.3 & 0.8 & 3 & \\
\hline Arenaria macradenia & 0.5 & 1.2 & 2 & \\
\hline Astragalus albens & 0.9 & 1.4 & 3 & \\
\hline Astragalus leucolobus & 0.7 & 1.0 & 2 & \\
\hline Bromus rubens & $t$ & $t$ & 2 & \\
\hline Bromus tectorum & 1.5 & 1.2 & 5 & c \\
\hline Castilleja chromosa & 0.3 & 0.8 & 2 & \\
\hline Caulanthus cooperi & 0.3 & 0.8 & 2 & \\
\hline Caulanthus major & 0.3 & 0.8 & 1 & \\
\hline Chamaesyce albomarginata & 0.3 & 0.8 & 2 & \\
\hline Cordylanthus nevinii & 0.2 & 0.4 & 2 & \\
\hline Cryptantha angustifolia & $t$ & $\mathbf{t}$ & 1 & \\
\hline Cryptantha sp. & 0.5 & 1.2 & 2 & \\
\hline Delphinium parishii & $\mathrm{t}$ & $t$ & 1 & \\
\hline Descurainea pinnata & 0.3 & 0.8 & 2 & \\
\hline Dudleya abramsii & 0.5 & 1.2 & 1 & \\
\hline Eriastrum densiflorum & 0.7 & 1.6 & 1 & \\
\hline Eriastrum saphirrinum saphirrinum & 0.7 & 1.6 & 2 & \\
\hline Erigeron breweri & 0.2 & 0.4 & 1 & \\
\hline Eriogonum davidsonii & 0.3 & 0.8 & 1 & \\
\hline Eriogonum ovalifolium vineum & 0.3 & 0.8 & 1 & \\
\hline Eriogonum saxatile & 0.3 & 0.8 & 1 & \\
\hline Eriogonum wrightii & $t$ & $\mathrm{t}$ & 1 & \\
\hline Eriophylium confertiflorum & $t$ & $t$ & $i$ & \\
\hline Erysimum capitatum & 0.2 & 0.4 & 1 & \\
\hline Eucrypta micrantha & $t$ & $\mathrm{t}$ & 1 & \\
\hline Festuca octoflora & 0.2 & 0.3 & 2 & \\
\hline Galium angustifolium & 0.3 & 0.8 & 3 & \\
\hline Gilia austrooccidentalis & 1.5 & 1.2 & 6 & c \\
\hline Hulsea vestita vestita & 0.2 & 0.4 & 1 & \\
\hline Hymenopappus filifolius & $t$ & $t$ & 1 & $f$ \\
\hline Lomatium mojavense & 0.4 & 1.1 & 1 & \\
\hline Lotus argyraeus & 0.3 & 0.7 & 1 & \\
\hline Machaeranthera canescens & 0.3 & 0.7 & 1 & \\
\hline Mentzelia sp. & 0.4 & 1.1 & 1 & \\
\hline Mimulus longiflorus & 0.3 & 0.7 & 1 & \\
\hline Nama demissum & 0.5 & 1.4 & 1 & \\
\hline Nemacladus sp. & 0.4 & 1.1 & 1 & \\
\hline
\end{tabular}


Appendix 17: Species list for Piñon-Juniper Woodland with Yucca VT (PJW-Y; $\underline{n}=15)$.

Frequencies are shown (Freq.), as well as designations (Desig.), including dominant species (d), species with high constancy (c; $>80 \%$ of occurrences in only one VT), species with high fidelity (f; occurred in $>50 \%$ of plots in this VT), and indicator species (i). Less than 0.1 mean percentage cover or mean relative abundance is indicated by a " 4 ".

\begin{tabular}{lcccc}
\hline Species & Mean & SD & Freq. & Desig. \\
\hline Herbs (Rel. Abund.): & & & & \\
Penstemon eatonii & 0.3 & 0.7 & 1 & \\
Phacelia campanularia & 0.4 & 1.1 & 1 & \\
Phacelia cicutaria & 0.1 & 0.4 & 1 & \\
Phacelia cryptantha & 0.4 & 1.1 & 1 & \\
Phacelia curvipes & 0.1 & 0.4 & 1 & \\
Phacelia douglasii & 0.3 & 0.7 & 1 & \\
Phacelia fremontii & 0.8 & 1.0 & 3 & \\
Stephanomeria myrioclada & 0.9 & 1.3 & 3 & \\
Stephanomeria virgata & 0.1 & 0.4 & 1 & \\
& & & & \\
\hline
\end{tabular}


Appendix 18: Species list for Piñon-Juniper Woodland with Shrub Live Oak Woodland VT (PJW-SLO; $\underline{n}=15)$. Frequencies are shown (Freq.), as well as designations (Desig.), including dominant species (d), species with high constancy (c; $>80 \%$ of occurrences in only one VT), species with high fidelity (f; occurred in $>50 \%$ of plots in this VT), and indicator species (i). Less than 0.1 mean percentage cover or mean relative abundance is indicated by a " $t$ ".

\begin{tabular}{|c|c|c|c|c|}
\hline Species & Mean & SD & Freq. & Desig. \\
\hline \multicolumn{5}{|l|}{ Overstory (\% Cover): } \\
\hline Juniperus californica & 0.2 & 0.8 & 1 & \\
\hline Juniperus osteosperma & 1.2 & 1.5 & 6 & \\
\hline Pinus monophylla & 17.2 & 13.4 & 15 & c \\
\hline Quercus turbinella & 13.2 & 13.0 & 9 & $c, d, f$ \\
\hline Yucca brevifolia & 0.1 & 0.2 & 3 & \\
\hline \multicolumn{5}{|l|}{ Shrubs (\% Cover): } \\
\hline Amorpha californica & 0.2 & 0.8 & 1 & \\
\hline Arctostaphylos glauca & 2.5 & 6.1 & 3 & \\
\hline Ariemisia tridentata & 2.0 & 4.5 & 5 & \\
\hline Ceanothus gregii vestitus & 0.6 & 1.2 & 3 & \\
\hline Cercocarpus betuloides & 1.2 & 4.5 & 1 & f \\
\hline Chrysothamnus viscidiflorus stenophyllus & 1.9 & 2.2 & 8 & c \\
\hline Coleogyne ramosissima & 0.2 & 0.8 & 1 & \\
\hline Echinocereus engelmannii & 0.4 & 1.1 & 2 & \\
\hline Echinocereus triglochidiatus mojavensis & 0.5 & 1.0 & 6 & \\
\hline Ephedra nevadensis & 0.0 & 0.1 & 1 & \\
\hline Ephedra viridis & 1.3 & 2.2 & 1 & \\
\hline Eriodictyon trichocalyx & 0.2 & 0.8 & 1 & \\
\hline Eriogonum fasiculatum polifolium & 3.2 & 4.7 & 8 & c \\
\hline Fremontodendron californicum & 0.5 & 1.9 & 1 & \\
\hline Gutierrezia microcephala & 0.9 & 2.1 & 3 & \\
\hline Gutierrezia sarothrae & 0.2 & 0.8 & 1 & \\
\hline Haplopappus cuneatus & 0.4 & 1.1 & 2 & \\
\hline Haplopappus linearifolius & 3.5 & 2.3 & 13 & c, d \\
\hline Leptodactylon pungens & 1.3 & 1.5 & 8 & c \\
\hline Mirabilis bigelovii & 0.2 & 0.8 & 2 & \\
\hline Nolina parryi & 1.2 & 2.1 & 6 & $f, i$ \\
\hline Opuntia basilaris basilaris & 1.9 & 1.4 & 13 & $c, i$ \\
\hline Opuntia littoralis piercii & 0.4 & 1.1 & 3 & \\
\hline Phorodendron bolleanum densum & 0.2 & 0.8 & 1 & \\
\hline Purshia glandulosa & 2.1 & 2.1 & 9 & c \\
\hline Rhamnus ilicifolia & 0.5 & 1.9 & 1 & \\
\hline Rhus trilobata & 0.2 & 0.8 & 1 & \\
\hline Salazariamexicana & 0.2 & 0.8 & 1 & \\
\hline Salvia dorii & 0.4 & 1.1 & 2 & \\
\hline Yucca schidigera & 1.6 & 1.6 & 8 & c \\
\hline
\end{tabular}


Appendix 18: Species list for Piñon-Juniper Woodland with Shrub Live Oak Woodland VT (PJW-SLO; $\mathrm{n}=15$ ). Frequencies are shown (Freq.), as well as designations (Desig.), including dominant species (d), species with high constancy (c; $>80 \%$ of occurrences in only one VT), species with high fidelity ( $f$; occurred in $>50 \%$ of plots in this VT), and indicator species (i). Less than 0.1 mean percentage cover or mean relative abundance is indicated by a " $t$ ".

\begin{tabular}{llll}
\hline Species & Mean & SD & Freq.
\end{tabular}

Perennial Buncharasses

\% Cov./Rel. Abund.):

Aristida fendleriana

Poa fendleriana

Poa secunda

Sitanion hystrix

Stipa coronata depauperata

Stipa speciosa

$\begin{array}{rrrr}0.8 / 0.9 & 1.1 / 1.3 & 6 & \\ 0.2 / 0.3 & 0.8 / 0.9 & 2 & \\ 0.8 / 0.1 & 1.4 / 0.5 & 1 & \\ 0.9 / 0.9 & 1.3 / 1.1 & 7 & \\ 3.4 / 2.8 & 1.8 / 0.8 & 15 & c \\ 2.7 / 2.3 & 1.8 / 1.2 & 13 & c\end{array}$

Herbs (Rel. Abund.):

Allium sp.

Arabis pulchra

Arabis shockleyi

Arenaria macradenia

Artemisia leudoviciana

Astragalus albens

Astragalus douglasii

Brickellia oblongifolia linifolia

Bromus rubens

Bromus tectorum

Calycoseris parryi

Cammisonia sp.

Castilleja chromosa

Caulanthus major

Chamaesyce albomarginata

Chaenactis santolinioides

Chenopodium fremontii

Cordylanthus nevinii

Cryptantha holoptera

Cryptantha utaherisis

Descurainea pinnata

Eriastrum sapphirinum sapphirinum

Erigeron aphanactis

Erigeron breweri

Eriogonum davidsonii

Eriogonum kennedyi

Eriogonum saxatile

Eriogonum wrightii

Eriophyllum lanatum

$\begin{array}{llll}0.1 & 0.5 & 1 \\ 0.3 & 0.7 & 2 \\ 0.1 & 0.5 & 1 \\ 0.1 & 0.5 & 1 \\ 0.3 & 0.9 & 2 \\ 0.1 & 0.5 & 1 \\ 0.1 & 0.3 & 1 \\ 0.2 & 0.4 & 3 & \\ 0.3 & 0.9 & 2 & \\ 0.9 & 1.2 & 6 & \\ 0.1 & 0.3 & 1 & \\ t & t & 1 & \\ 0.3 & 0.6 & 3 & \\ 0.3 & 0.7 & 3 & \\ 0.1 & 0.5 & 1 & \\ 0.5 & 1.1 & 3 & \\ 0.1 & 0.5 & 1 & \\ 1.1 & 1.6 & 5 & \\ 0.2 & 0.8 & 1 & \\ 0.5 & 1.3 & 2 \\ 0.4 & 1.1 & 2 & \\ 0.2 & 0.8 & 1 & \\ 0.1 & 0.3 & 1 & \\ 0.4 & 0.9 & 3 \\ 0.2 & 0.6 & 2 \\ 1.3 & 0.5 & 1 & \\ 0.4 & 0.7 & 4 & \\ 0.2 & 0.8 & 1 & \\ 1.2 & 1.2 & 9\end{array}$


Appendix 18: Species list for Piñon-Juniper Woodland with Shrub Live Oak Woodland VT (PJW-SLO; $\underline{n}=15$ ). Frequencies are shown (Freq.), as well as designations (Desig.), including dominant species (d), species with high constancy (c; $>80 \%$ of occurrences in only one VT), species with high fidelity (f; occurred in $>50 \%$ of plots in this VT), and indicator species (i). Less than 0.1 mean percentage cover or mean relative abundance is indicated by a "t".

\begin{tabular}{lllll}
\hline Species & Mean & SD & Freq. & Desig. \\
\hline Herbs (Rel. Abund.): & & & & \\
Galium angustifolium & & & & \\
Galium parishii & 1.2 & 1.3 & 8 & $\mathrm{C}, \mathrm{d}$ \\
Gilia austrooccidentalis & 0.1 & 0.5 & 1 & \\
Hulsea vestita vestita & 0.5 & 1.1 & 3 & \\
Linanthus breviculus & 0.1 & 0.3 & 1 & \\
Lomatium mojavense & 0.2 & 0.8 & 1 & \\
Lotus strigosus & 0.1 & 0.3 & 1 & \\
Machaeranthera canescens & 0.7 & 1.1 & 6 & $\mathrm{f}$ \\
Mentzelia sp. & 0.1 & 0.6 & 1 & \\
Nemacladus longiflorus & 0.1 & 0.3 & 1 & \\
Nemaclauius sp. & 0.1 & 0.5 & 1 & \\
Penstemon eatonii & 0.3 & 0.7 & 2 & \\
Phacelia bicolor & 0.1 & 0.4 & 2 & \\
Phacelia douglasii & 0.1 & 0.5 & 1 & $\mathrm{f}$ \\
Phacelia fremontii & 0.1 & 0.5 & 1 & \\
Phlox austromontanum & 0.2 & 0.6 & 2 & \\
Potentilla glandulosa & 0.1 & 0.5 & 1 & \\
Stephanomeria myrioclada & 0.1 & 0.3 & 1 & $\mathrm{f}$ \\
Ferocactus laciniatus & 0.2 & 0.3 & 1 & $\mathrm{f}$ \\
& 0.1 & 0.5 & 1 & $\mathrm{f}$ \\
\hline
\end{tabular}


Appendix 19: Species list for Piñon Woodland with Joshua Tree VT (PW-JT; $\underline{n}=14)$.

Frequencies are shown (Freq.), as well as designations (Desig.), including dominant species (d), species with high constancy (c; $>80 \%$ of occurrences in only one VT), species with high fidelity (f; occurred in $>50 \%$ of plots in this VT), and indicator species (i). Less than 0.1 mean percentage cover or mean relative abundance is indicated by a "t".

\begin{tabular}{|c|c|c|c|c|}
\hline Species & Mean & SD & Freq. & Desig. \\
\hline \multicolumn{5}{|l|}{ Overstory (\% Cover): } \\
\hline $\begin{array}{l}\text { Juniperus californica } \\
\text { Juniperus occidentalis }\end{array}$ & $\begin{array}{l}2.5 \\
1.3\end{array}$ & $\begin{array}{l}6.4 \\
4.7\end{array}$ & $\begin{array}{l}2 \\
1\end{array}$ & $f$ \\
\hline Juniperus osteosperma & 0.5 & 2.0 & 2 & d \\
\hline Pinus monophylla & 16.7 & 15.3 & 16 & c \\
\hline Yucca brevitolia & 2.6 & 4.8 & & c, d \\
\hline \multicolumn{5}{|l|}{ Shrubs (\% Cover): } \\
\hline Amelanchier utahensis & $t$ & $t$ & 1 & \\
\hline Artemisia tridentata & 14.1 & 11.7 & 14 & c \\
\hline Atriplex canescens & 0.2 & 0.8 & 2 & \\
\hline Brickellia califomica & 0.2 & 0.8 & 1 & \\
\hline Ceanothus gregii vestitus & 0.2 & 0.8 & 1 & \\
\hline Cercocarpus ledifolius & $t$ & $t$ & 1 & \\
\hline Chrysothamnus nauseosus & 0.8 & 2.1 & 4 & \\
\hline Chrysothamnus viscidiflorus stenophyllus & 1.2 & 2.2 & 8 & $\mathbf{i}$ \\
\hline Ephedra viridis & 4.2 & 4.1 & 12 & $c, i$ \\
\hline Eriodictyon trichocalyx & 0.2 & 0.8 & 1 & \\
\hline Eriogonum fasiculatum polifolium & 0.2 & 0.8 & 1 & \\
\hline Eriogonum microthecum corymbosoides & $\mathrm{t}$ & $t$ & 1 & \\
\hline Eurotia lanatum & $t$ & $t$ & 2 & \\
\hline Fremontodendron californicum & 1.3 & 4.7 & 2 & \\
\hline Gutierrezia microcephala & 2.4 & 4.9 & 8 & \\
\hline Gutierrezia sarothrae & 1.7 & 4.7 & 4 & \\
\hline Haplopappus cuneatus & 0.4 & 1.1 & 2 & \\
\hline Haplopappus linearifolius & 0.5 & 2.0 & 1 & $\mathbf{i}$ \\
\hline Leptodactylon pungens & 0.2 & 0.8 & 1 & \\
\hline Mirabilis bigelovii & 0.0 & 0.1 & 1 & \\
\hline Opuntia basilaris basilaris & 0.7 & 1.3 & 8 & \\
\hline Opuntia echinocarpa & 0.9 & 1.4 & 5 & \\
\hline Opuntia erinacea & 0.3 & 0.8 & 4 & \\
\hline Opuntia littoralis piercii & 0.3 & 0.8 & 4 & \\
\hline Petalonyx nitidum & 0.0 & 0.1 & 1 & \\
\hline Phoradendron bolleanum densum & $t$ & $t$ & 1 & \\
\hline Prunus fasiculatum & 0.5 & 2.0 & 4 & \\
\hline Purshia glandulosa & 6.5 & 5.3 & 12 & c \\
\hline Salvia pachyphylla & 1.2 & 2.2 & 5 & \\
\hline
\end{tabular}


Appendix 19: Species list for Piñon Woodland with Joshua Tree VT (PW-JT; $\underline{n}=14)$.

Frequencies are shown (Freq.), as well as designations (Desig.), including dominant species (d), species with high constancy ( $c ;>80 \%$ of occurrences in only one VT), species with high fidelity ( $f$; occurred in $>50 \%$ of plots in this VT), and indicator species (i). Less than 0.1 mean percentage cover or mean relative abundance is indicated by a " $t$ ".

\begin{tabular}{lcccc}
\hline Species & Mean & SD & Freq. & Desig. \\
\hline Perennial Bunchgrasses & & & & \\
\hline (\% Cov./Rel. Abund.): & & & & \\
Bouteloua gracilis & $3.4 / 0.7$ & $10.0 / 1.4$ & 5 & \\
Melica stricta & $\mathrm{t} / \mathrm{t}$ & $\mathrm{t} / \mathrm{t} .4$ & 3 & $\mathrm{f}$ \\
Oryzopsis hymenoides & $\mathrm{t} / 0.5$ & $\mathrm{t} / 0.9$ & 5 & \\
Poa fendleriana & $0.6 / 0.8$ & $1.1 / 1.2$ & 7 & \\
Poa secunda & $0.2 / 0.3$ & $1.1 / 0.9$ & 2 & \\
Sitanion hystrix & $1.9 / 2.0$ & $1.4 / 1.2$ & 11 & $\mathrm{c}$ \\
Stipa coronata depauperata & $0.3 / 0.4$ & $0.8 / 1.0$ & 3 & \\
Stipa speciosa & $1.1 / 0.9$ & $1.5 / 1.2$ & 8 &
\end{tabular}

Herbs (Rel. Abund.)

Allium campanulatum

Arabis pulchra

Artemisia dracunculus

Astragalus albens

Astragalus bernardinus

Astragalus bicristatus

Astragalus leucolobus

Brickellia oblongifolia linifolia

Bromus tectorum

Castilleja chromosa

Castilleja linearifolia

Caulanthus major

Chaenactis santolinoides

Chamaesyce sp.

Chamaesyce albomarginata

Cordylanthus nevinii

Cryptantha circumsissa

Cryptantha holoptera

Cryptantha micrantha

Cryptantha nevadensis

Cryptantha pterocarya

Cryptantha racemosa

Cryptantha sp.

Cryptantha utahensis

Descurainea pinnata

Eriastrum saphirrinum saphirrinum

Erigeron aphanactis

Erigeron breweri

Eriogonum davidsonii

$\begin{array}{rrrr}0.2 & 0.8 & 1 & \\ 0.9 & 1.2 & 10 & c \\ 0.1 & 0.3 & 2 & \\ 0.2 & 0.5 & 2 & \\ 0.2 & 0.9 & 1 & \\ 0.1 & 0.3 & 1 & \\ 0.1 & 0.3 & 1 & \\ 0.3 & 0.6 & 3 & \\ 1.9 & 1.4 & 14 & \mathrm{c} \\ 0.1 & 0.5 & 4 & \\ \mathrm{t} & \mathrm{t} & 1 & \\ 0.6 & 1.0 & 4 & \\ 0.1 & 0.3 & 1 & \\ 0.1 & 0.3 & 1 & f \\ 0.9 & 1.4 & 6 & \\ 0.2 & 0.6 & 2 & \\ 0.2 & 0.8 & 1 & \\ 0.1 & 0.5 & 1 & \\ 0.1 & 0.5 & 1 & \\ \mathrm{t} & \mathrm{t} & 2 & \\ 0.5 & 1.0 & 3 & \\ 0.4 & 1.1 & 2 & f \\ 0.5 & 1.0 & 4 & \\ 0.4 & 1.1 & 2 & \\ 1.3 & 1.4 & 11 & \mathrm{c} \\ 0.3 & 0.7 & 2 & \\ 0.2 & 0.8 & 1 & \\ 0.2 & 0.8 & 1 & \\ 0.4 & 0.8 & 5 & \end{array}$


Appendix 19: Species list for Piñon Woodland with Joshua Tree VT (PW-JT; $\underline{n}=14)$. Frequencies are shown (Freq.), as well as designations (Desig.), including dominant species (d), species with high constancy ( $c ;>80 \%$ of occurrences in only one VT), species with high fidelity ( $f$; occurred in $>50 \%$ of plots in this VT), and indicator species (i). Less than 0.1 mean percentage cover or mean relative abundance is indicated by a " $t$ ".

\begin{tabular}{lcccc}
\hline Species & Mean & SD & Freq. & Desig. \\
\hline Herbs (Rel. Abund.): & & & & \\
Eriogonum saxatile & 0.4 & 0.9 & 3 & \\
Eriogonum umbellatum munzii & 0.5 & 1.1 & 3 & \\
Eriogonum wrightii & 0.5 & 1.3 & 2 & \\
Galium angustifolium & $t$ & $t$ & 1 & \\
Galium hilendiae & 0.3 & 1.1 & 1 & \\
Gallium parishii & 0.3 & 0.7 & 2 & \\
Gayophytum diffusum & 0.2 & 0.6 & 2 & \\
Gilia austrooccidentalis & 1.4 & 1.5 & 10 & $\mathrm{c}$ \\
Langloisia matthewsii & 0.1 & 0.5 & 3 & \\
Linanthus breviculus & 0.5 & 0.8 & 5 & \\
Lomatium mohavense & 0.1 & 0.2 & 1 & \\
Machaeranthera canescens & 0.2 & 0.7 & 2 & \\
Malacothamnus orbiculatus & 0.1 & 0.2 & 1 & \\
Mentzelia albicaulis & 0.2 & 0.7 & 1 & \\
Mentzelia montana & 0.2 & 0.6 & 2 & \\
Mentzelia sp. & 0.2 & 0.6 & 1 & \\
Oenothera californica & 0.1 & 0.5 & 1 & \\
Orcuttia californica & 0.1 & 0.2 & 1 & \\
Penstemon eatonii & 0.2 & 0.5 & 2 & \\
Phacelia distans & 0.1 & 0.5 & 1 & \\
Phacelia fremontii & 1.0 & 1.3 & 8 & \\
Phacelia gracilis & 0.1 & 0.5 & 1 & \\
Phlox austromontanum & 0.6 & 1.0 & 5 & \\
Plagiobothrys hispidulus & 0.1 & 0.3 & 2 & \\
Salsola kali & 0.1 & 0.5 & 1 & \\
Senecio bernardinus & 0.1 & 0.2 & 1 & \\
Silene verecunda & 0.1 & 0.2 & 1 & \\
Sisymbrium altissimum & 0.3 & 0.8 & 2 & \\
Sphaeralcea ambigua & 0.3 & 0.7 & 3 & \\
Stephanomeria exigua & 0.1 & 0.2 & 1 & \\
Stephanomeria virgata & 0.2 & 0.5 & 2 & \\
Tragopogon porrifolium & 0.1 & 0.3 & 2 & \\
& & & & \\
& & & & \\
\end{tabular}


Appendix 20: Species list for Piñon Woodland with Canyon Live Oak VT (PW-CLO; $\underline{n}=13$ ). Frequencies are shown (Freq.), as well as designations (Desig.), including dominant species (d), species with high constancy ( $c ;>80 \%$ of occurrences in only one VT), species with high fidelity ( $f$; occurred in $>50 \%$ of plots in this VT), and indicator species (i). Less than 0.1 mean percentage cover or mean relative abundance is indicated by a " $\mathrm{t}$ ".

\begin{tabular}{lllll}
\hline Species & Mean & SD & Freq. Desig.
\end{tabular}

Overstory (\% Cover):

Juniperus occidentalis

Juniperus osteosperma

Pinus monophylla

Quercus chrysolepis

Yucca brevifolia

Shrubs (\% Cover):

Amelanchier utahensis

Amorpha californica

Arctostaphylos glauca

Artemisia tridentata

Ceanothus greggii vestitus

Chrysothamnus nauseosus

Chrysothamnus viscidiflorus stenophyllus

Echinocereus triglochidiatus mojavensis

Ephedra viridis

Eriodictyon trichocalyx

Eriogonum fasiculatum polifolium

Eriogonum heermannii

Eriogonum microthecum corymbosoides

Fremontodendron californicum

Gutierrezia microcephala

Gutierrezia sarothrae

Haplopappus cuneatus

Haplopappus linearifolius

Leptodactylon pungens

Opuntia basilaris basilaris

Opuntia erinacea

Opuntia littoralis piercii

Phorodendron bolleanum densum

Purshia glandulosa

Salvia dorrii

Salvia pachyphylla

Yucca schidigera

$\begin{array}{llr}2.9 & 6.5 & 3 \\ 1.4 & 4.9 & 1 \\ 30.0 & 23.4 & 10 \\ 6.4 & 8.0 & 7 \\ 0.9 & 1.4 & 4\end{array}$

C

$7 \quad$ c, i

$0.1 \quad 0.2$

0.5

2.7

5.1

1.1

6.6

$2.0 \quad 4.8$

$1.0 \quad 2.2$

$2.2 \quad 5.1$

$0.3 \quad 0.8$

$0.5 \quad 1.1$

$0.2 \quad 0.8$

$0.5 \quad 1.1$

$t$

0.2

5.3

0.5

0.3

0.5

1.6

0.3

1.7

0.2

0.7

0.5

3.8

0.0

0.2

$t$

1

0.8

10.9

1.1

0.8

1.1

4.8

0.8

1.5

0.8

1.3

1.1

5.1

0.1

0.8

c, d

$$
\text { i }
$$

d

c

c, d 
Appendix 20: Species list for Piñon Woodland with Canyon Live Oak VT (PW-CLO; $\underline{n}=13$ ). Frequencies are shown (Freq.), as well as designations (Desig.), including dominant species (d), species with high constancy ( $c ;>80 \%$ of occurrences in only one VT), species with high fidelity ( $f$; occurred in $>50 \%$ of plots in this VT), and indicator species (i). Less than 0.1 mean percentage cover or mean relative abundance is indicated by a " $\mathrm{t}$ ".

\begin{tabular}{|c|c|c|c|c|}
\hline Species & Mean & $\mathrm{SD}$ & Freg. & Desig \\
\hline \multicolumn{5}{|l|}{ Perennial Bunchgrasses } \\
\hline \multicolumn{5}{|l|}{ (\% Cov./Rel. Abund.): } \\
\hline Bouteloua gracilis & $0.2 / 0.2$ & $0.8 / 0.6$ & 1 & \multirow{6}{*}{$c, i$} \\
\hline Oryzopsis hymenoides & $0.2 / 0.2$ & $0.8 / 0.6$ & 1 & \\
\hline Poa fendleriana & $2.1 / 1.9$ & $1.4 / 1.3$ & 10 & \\
\hline Poa secunda & $0.0 / 0.2$ & $0.1 / 0.6$ & 1 & \\
\hline Sitanion hystrix & $1.0 / 1.2$ & $1.4 / 1.5$ & 6 & \\
\hline Sporobolus cryptandrus & $0.0 / 0.2$ & $0.1 / 0.6$ & 1 & \\
\hline Stipa coronata depauperata & $2.4 / 1.7$ & $2.1 / 1.4$ & 9 & c \\
\hline Stipa speciosa & $0.7 / 0.6$ & $1.3 / 1.2$ & 3 & \\
\hline \multicolumn{5}{|l|}{ Herbs (Rel. Abund.): } \\
\hline Arabis pulchra & 0.8 & 0.8 & 7 & \multirow[t]{28}{*}{ c } \\
\hline Arceuthobium divaricatum & 0.2 & 0.4 & 2 & \\
\hline Arenaria macradenia & 0.2 & 0.8 & 1 & \\
\hline Artemisia ludoviciana & 0.3 & 0.8 & 2 & \\
\hline Astragalus leucolobus & 0.1 & 0.3 & 1 & \\
\hline Brickellia oblongifolia linifolia & 0.2 & 0.6 & 2 & \\
\hline Bromus tectorum & 1.2 & 1.6 & 5 & \\
\hline Castilleja chromosa & 0.2 & 0.6 & 2 & \\
\hline Caulanthus major & 0.8 & 1.0 & 5 & \\
\hline Chamaesyce albomarginata & 0.3 & 0.9 & 2 & \\
\hline Chaenactis santolinoides & 0.5 & 1.1 & 3 & \\
\hline Cordylanthus nevinii & 0.6 & 1.5 & 2 & \\
\hline Cryptantha circumsissa & 0.2 & 0.8 & 1 & \\
\hline Cryptantha echinella & 0.2 & 0.6 & 1 & \\
\hline Cryptantha holoptera & 0.2 & 0.8 & $i$ & \\
\hline Cryptantha nevadensis & 0.4 & 1.0 & 2 & \\
\hline Cryptantha sp. & 0.3 & 0.8 & 2 & \\
\hline Descurainea pinnata & 0.2 & 0.6 & 1 & \\
\hline Eriastrum densiflorum & 0.1 & 0.3 & 1 & \\
\hline Eriastrum saphirrinum saphirrinum & 0.5 & 1.2 & 2 & \\
\hline Erigeron aphaenactis & 0.1 & 0.3 & 1 & \\
\hline Erigeron breweri & 0.3 & 0.9 & 2 & \\
\hline Eriogonum davidsonii & 0.2 & 0.8 & 1 & \\
\hline Eriogonum saxatile & 0.2 & $0 . €$ & $i$ & \\
\hline Eriogonum umbellatum munzii & 0.2 & 0.6 & 1 & \\
\hline Eriogonum wrightii & 0.2 & 0.8 & 1 & \\
\hline Eriophyllum lanatum & 0.2 & 0.6 & 2 & \\
\hline Erysimum capitatum & 0.1 & 0.3 & 1 & \\
\hline
\end{tabular}


Appendix 20: Species list for Piñon Woodland with Canyon Live Oak VT (PW-CLO; $\underline{n}=13$ ). Frequencies are shown (Freq.), as well as designations (Desig.), including dominant species (d), species with high constancy (c; $>80 \%$ of occurrences in only one VT), species with high fidelity (f; occurred in $>50 \%$ of plots in this VT), and indicator species (i). Less than 0.1 mean percentage cover or mean relative abundance is indicated by a "t".

\begin{tabular}{lcccc}
\hline Species & Mean & SD & Freq. & Desig. \\
\hline Herbs (Rel. Abund.): & & & & \\
Galium parishii & 0.5 & 1.1 & 2 \\
Gilia austrooccidentalis & 0.5 & 1.0 & 3 & \\
Lepidium lasiocarpum & 0.1 & 0.3 & 1 & \\
Linanthus breviculus & 0.2 & 0.6 & 1 \\
Machaeranthera canescens & 0.2 & 0.8 & 1 \\
Malacothamnus orbiculatus & 0.1 & 0.3 & 1 \\
Oenothera californica & 0.1 & 0.3 & 1 \\
Penstemon eatonii & 0.2 & 0.4 & 3 \\
Phacelia fremontii & 0.3 & 0.8 & 2 \\
Phlox austromontanum & 0.7 & 1.2 & 4 \\
Salsola kali & 0.3 & 0.8 & 1 \\
Sisymbrium altissimum & 0.2 & 0.8 & 1 \\
Sphaeralcea ambigua & 0.5 & 1.1 & 2 & \\
Stephanomeria virgata & 0.2 & 0.8 & 1 & \\
& & & & \\
\hline
\end{tabular}


Appendix 21: Species list for Yellow Pine Forest-Piñon Woodland transition VT (YPF-PW; $\mathrm{n}=13$ ). Frequencies are shown (Freq.), as well as designations (Desig.), including dominant species (d), species with high constancy (c; $>80 \%$ of occurrences in only one VT), species with high fidelity ( $\mathrm{f}$; occurred in $>50 \%$ of plots in this VT), and indicator species (i). Less than 0.1 mean percentage cove: or mean relative abundance is indicated by a " $\mathrm{t}$ ".

\begin{tabular}{lllll}
\hline Species & Mean & SD & Freg. Desig.
\end{tabular}

Overstory (\% Cover):

Abies concolor

Juniperus occidentalis

Juniperus osteosperma

Pinus jeffreyi

Pinus lambertiana

Pinus monophylla

Quercus chrysolepis

Shrubs (\% Cover):

Amplanchier utahensis

Amorpha californica

Arctostaphylos patula

Artemisia tridentata

Ceanothus greggii vestitus

Cercocarpus ledifolius

Chrysothamnus nauseosus

Chrysothamnus viscidiflorus stenophyllus

Echinocereus triglochidiatus mojavensis

Eriogonum fasiculatum politolium

Eriogonum microthecum corymbosoides

Fremontodendron californicum

Haplopappus linearifolius

Leptodactylon pungens

Mirabilis bigelovii

Opuntia basilaris basilaris

Opuntia littoralis piercii

Petalonyx nitidum

Phorodendron bolleanum densum

Ribes velutinum

Salvia pachyphylla

Symphoricarpos parishii

Tetradymia canescens

Yucca shidigera
2.4

2.7

0.0

9.7

1.4

13.1

15.7

$\$$
5.0

5.1

0.1

13.2

4.5

14.5

13.3

$0.4 \quad 1.1$

$0.9 \quad 2.1$

$1.4 \quad 4.5$

$2.8 \quad 6.1$

$0.6 \quad 1.2$

7.4

0.6

0.2

0.0

0.2

0.2

0.2

0.4

0.2

0.3

1.1

0.4

$\mathrm{t}$

0.2

0.4

0.4

0.0

0.4

t

0.8

0.1

0.8

0.8

0.8

1.1

0.8

0.1

1.4

1.1

t

0.8

1.1

1.1

0.1

1.1 i

$c, d, f, i$

$t$

$c$

$c, d$

d

2 
Appendix 21: Species list for Yellow Pine Forest-Piñon Woodland transition VT (YPF-PW; $\underline{n}=13$ ). Frequencies are shown (Freq.), as well as designations (Desig.), including dominant species (d), species with high constancy (c; $>80 \%$ of occurrences in only one VT), species with high fidelity ( $f$; occurred in $>50 \%$ of plots in this VT), and indicator species (i). Less than 0.1 mean percentage cover or mean relative abundance is indicated by a " $t$ ".

\begin{tabular}{lllll}
\hline Species & Mean & SD & Freq. Desig.
\end{tabular}

Perennial Bunchgrasses

(\% Cov./Rel. Abund.):

Melica stricta

Poa fendleriana

Poa secunda

Sitanion hystrix

Stipa coronata depauperata

Stipa speciosa

Mean

Herbs (Rel. Abund.):

Arabis pulchra

Arabis shockleyi

Artemisia ludoviciana

Astragalus bicristatus

Astragalus leucolobus

Bromus tectorum

Castilleja chromosa

Caulanthus major

Chaenactis santolinoides

Chenopodium fremontii

Cordylanthus nevinii

Cryptantha echinella

Cryptantha micrantha

Eriastrum saphirrinum saphirrinum

Erigeron breweri

Eriogonum kennedyi

Eriogonum parishii

Eriogonum umbellatum munzii

Eriogonum wrightii

Erysimum capitatum

Galium angustifolium

Galium parishii

Gayophytum diffusum

Gilia austrooccidentalis

Heuchera parishii

Linanthus breviculus

Langloisia mathewsii

Lomatium mojavense

Lotus argyraeus

$\begin{array}{llrl}0.1 / \mathrm{t} & 0.2 / \mathrm{t} & 3 & \mathrm{f} \\ 1.4 / 1.5 & 1.5 / 1.5 & 8 & \mathrm{c} \\ 0.2 / 0.1 & 0.8 / 0.5 & 1 & \\ 1.5 / 1.5 & 1.5 / 1.2 & 10 & \mathrm{c} \\ 1.5 / 1.5 & 1.5 / 1.4 & 9 & \mathrm{c} \\ 0.2 / 0.3 & 0.8 / 0.7 & 2 & \end{array}$

$\begin{array}{llll}0.3 & 0.6 & 3 & \\ 0.3 & 0.8 & 2 & \\ 0.3 & 1.0 & 1 & \\ 0.1 & 0.3 & 1 & \\ 0.3 & 0.7 & 3 & \\ 0.9 & 0.1 & 5 & \\ 0.1 & 0.5 & 1 & \\ 0.7 & 0.9 & 6 & \\ 0.3 & 0.7 & 3 & \\ 0.1 & 0.5 & 1 & \\ 0.5 & 1.3 & 2 & \\ 0.3 & 1.0 & 1 & \\ 0.1 & 0.5 & 1 & \\ 0.2 & 0.8 & 1 & \\ 0.3 & 0.9 & 2 & \\ 0.1 & 0.5 & 1 & \\ 0.3 & 0.8 & 2 & f \\ 0.1 & 0.5 & 1 & \\ 1.1 & 1.4 & 6 & \mathrm{~d}, \mathrm{i} \\ 0.3 & 0.7 & 3 & \mathrm{i} \\ 0.1 & 0.5 & 1 & \\ 1.3 & 1.4 & 7 & \mathrm{~d} \\ 0.5 & 1.0 & 3 & \\ 0.4 & 0.9 & 3 & \\ 0.1 & 0.5 & 1 & \mathrm{f} \\ 0.1 & 0.5 & 1 & \\ 0.3 & 0.8 & & \\ 0.2 & 0.4 & 3 & \\ 0.1 & 0.3 & 1 & \end{array}$


Appendix 21: Species list for Yellow Pine Forest-Piñon Woodland transition VT (YPF-PW; $\underline{n}=13$ ). Frequencies are shown (Freq.), as well as designations (Desig.), including dominant species (d), species with high constancy (c; $>80 \%$ of occurrences in only one VT), species with high fidelity ( $f$; occurred in $>50 \%$ of plots in this VT), and indicator species (i). Less than 0.1 mean percentage cover or mean relative abundance is indicated by a " $t$ ".

\begin{tabular}{lcccc}
\hline Species & Mean & SD & Freq. & Desig. \\
\hline Herbs (Rel. Abund.): & & & & \\
Lotus strigosus & $\mathrm{t}$ & $\mathrm{t}$ & 1 & \\
Mentzelia sp. & 0.1 & 0.5 & & \\
Mentzelia veatchiana & 0.2 & 0.8 & 1 & $\mathrm{f}$ \\
Mimulus purnureus & 0.1 & 0.5 & 1 & $\mathrm{f}$ \\
Mimulus suksdorfii & 0.1 & 0.5 & 1 & $\mathrm{f}$ \\
Monardella linoides & 1.1 & 1.5 & 6 & $\mathrm{~d}, \mathrm{f}, \mathrm{i}$ \\
Pedicularis semibarbarta & 0.3 & 0.8 & 2 & \\
Penstemon eatonii & 0.1 & 0.3 & 1 & \\
Penstemon grinellii & 0.2 & 0.6 & 2 & $\mathrm{f}$ \\
Penstemon labrosus & 0.5 & 0.8 & 4 & $\mathrm{f}$ \\
Phacelia gracilis & 0.1 & 0.5 & 1 & \\
Phlox austromontanum & 0.3 & 0.9 & 2 & \\
Phlox dolicantha & 0.3 & 0.9 & 2 & $\mathrm{f}$ \\
Senecio bernardinus & 0.4 & 0.8 & 3 & \\
Silene verecunda & 0.3 & 0.9 & 2 & \\
Viola purpurea & 0.1 & 0.3 & 1 & $\mathrm{f}$ \\
& & & &
\end{tabular}

